\title{
Biochemical and Clinical Impact of Organic Uremic Retention Solutes: A Comprehensive Update
}

\author{
Raymond Vanholder *, Anneleen Pletinck, Eva Schepers (i) and Griet Glorieux \\ Nephrology Section, Department of Internal Medicine, Ghent University Hospital, De Pintelaan 185, \\ 9000 Ghent, Belgium; anneleen.pletinck@ugent.be (A.P.); eva.schepers@ugent.be (E.S.); \\ griet.glorieux@ugent.be (G.G.) \\ * Correspondence: Raymond.Vanholder@UGent.be; Tel.:+32-9-226-14-61
}

Received: 28 November 2017; Accepted: 23 December 2017; Published: 8 January 2018

\begin{abstract}
In this narrative review, the biological/biochemical impact (toxicity) of a large array of known individual uremic retention solutes and groups of solutes is summarized. We classified these compounds along their physico-chemical characteristics as small water-soluble compounds or groups, protein bound compounds and middle molecules. All but one solute (glomerulopressin) affected at least one mechanism with the potential to contribute to the uremic syndrome. In general, several mechanisms were influenced for each individual solute or group of solutes, with some impacting up to 7 different biological systems of the 11 considered. The inflammatory, cardio-vascular and fibrogenic systems were those most frequently affected and they are one by one major actors in the high morbidity and mortality of CKD but also the mechanisms that have most frequently been studied. A scoring system was built with the intention to classify the reviewed compounds according to the experimental evidence of their toxicity (number of systems affected) and overall experimental and clinical evidence. Among the highest globally scoring solutes were 3 small water-soluble compounds [asymmetric dimethylarginine (ADMA); trimethylamine-N-oxide (TMAO); uric acid], 6 protein bound compounds or groups of protein bound compounds [advanced glycation end products (AGEs); p-cresyl sulfate; indoxyl sulfate; indole acetic acid; the kynurenines; phenyl acetic acid;] and 3 middle molecules [ $\beta_{2}$-microglobulin; ghrelin; parathyroid hormone). In general, more experimental data were provided for the protein bound molecules but for almost half of them clinical evidence was missing in spite of robust experimental data. The picture emanating is one of a complex disorder, where multiple factors contribute to a multisystem complication profile, so that it seems of not much use to pursue a decrease of concentration of a single compound.
\end{abstract}

Keywords: uremic toxins; uremic toxicity; uremia; Chronic Kidney Disease; CKD; cardiovascular disease; inflammation; fibrosis; patho-physiology CKD; middle molecules; protein bound uremic solutes; water-soluble uremic solutes

Key Contribution: This publication contains a comprehensive overview of the current knowledge on uremic toxicity, as well as an estimation of the degree of toxicity attributed to each individual toxin, and a classification according to the degree of known toxicity.

\section{Introduction}

The progressive loss of kidney function in many cases of Chronic Kidney Disease (CKD) is accompanied by the retention of a host of metabolites [1], due to a decrease in their renal clearance that is sometimes accompanied by a rise in generation [2]. Many of these solutes have been shown to exert biological activity, hence affecting the functioning of cells and organs, resulting in the uremic syndrome [3]. The responsible solutes then are called uremic toxins. 
At the end of 2016, it was decided to dedicate a special issue of the journal "Toxins" to uremic toxicity. This special issue now comes to an end and contains a number of reviews and original studies. With this narrative review, it is our intention to consider the whole spectrum of uremic toxicity. Such comprehensive review has to the best of our knowledge not been published lately with the last of such initiatives going back to almost 20 years ago [4]. As in the meanwhile much novel data has been generated, we thought it timely to collect this information again in one single publication.

The knowledge on the identity and the toxicity of the uremic toxins as well as their removal has grown exponentially in the last few years. Analysis of all publications considered for this review shows a rapid year by year increase in number (Figure 1). An encyclopedic listing of known uremic solutes in 2003 identified 90 different compounds [1] and another 56 were added when this effort was repeated in 2012 [5].

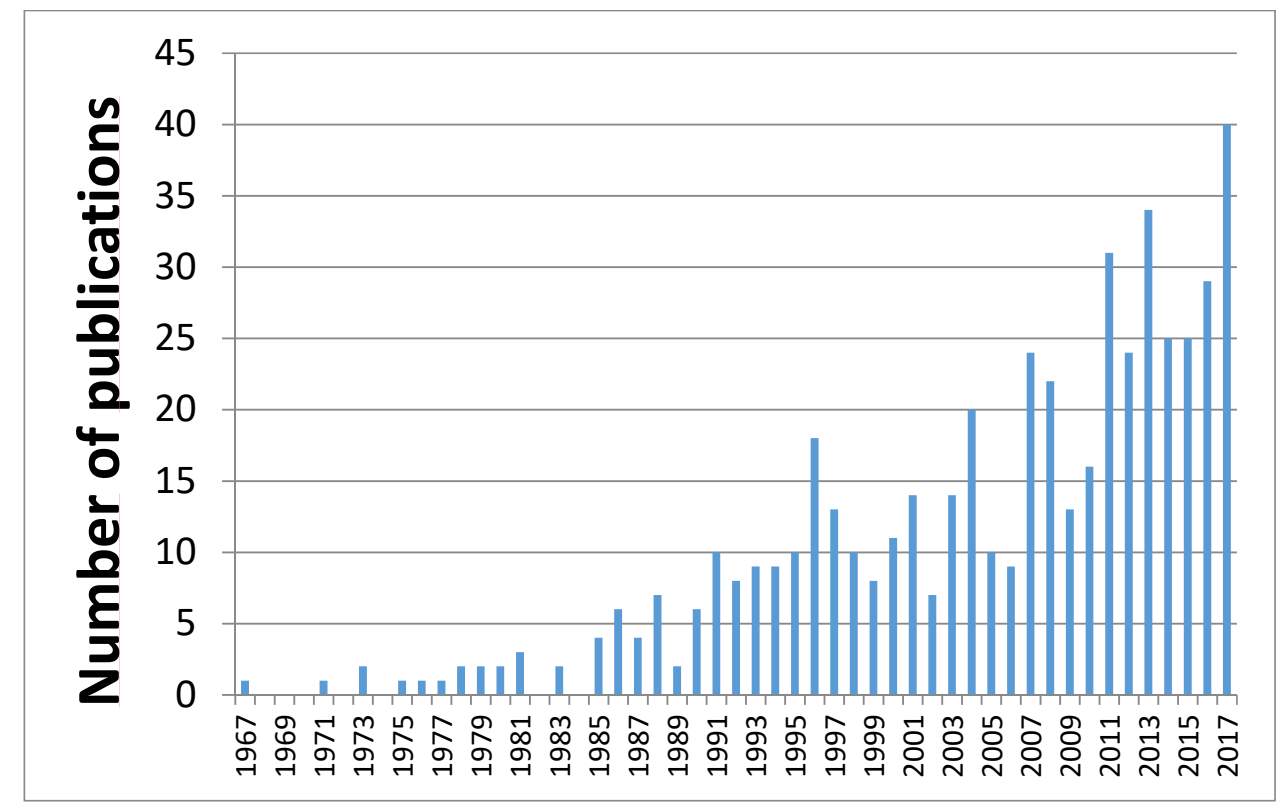

Figure 1. Number of publications per year of appearance included in the reference list of this article.

The recent acquisitions of metabolomic and proteomic research are enabling to further extend this list [6-15]. In spite of this almost unlimited possibility for identification it is more difficult and labor intensive to prove the toxicity of the newly detected molecules [6,7]. Hence, it is impossible to discuss all uremic retention solutes that are known today and this review is restricted to the most important ones, either because of their biologic effect or because of their association with clinical outcomes relevant to uremia.

To distinguish among uremic toxins, generally the classification into three major groups as proposed by the European Uremic Toxin Work Group (EUTox) and based on their removal pattern by dialysis is applied [1,16]. It distinguishes between: (1) small water-soluble compounds; (2) protein bound compounds; (3) the so-called middle molecules, which are mostly small peptides (Table 1). Although one could imagine other classification systems, e.g., based on the site of generation, e.g., intestinal or not [17], the currently used approach is preferred because, with the exception of transplantation, extracorporeal dialysis strategies unequivocally remain the most efficient interventional options to decrease the concentrations of these molecules. Such subdivision is in part artificial as in fact there is a continuum in degree of protein binding as well as of molecular weight of uremic solutes. For some (e.g., asymmetric dimethylarginine-ADMA), the degree of protein binding remains a matter of debate [18], whereas for others like p-cresyl glucuronide it is variable and so limited, that not much difference in removal pattern can be expected versus no protein binding [19]. 
Table 1. The different classes of uremic toxins as used in this publication.

\begin{tabular}{cccc}
\hline Class of Molecules & MW Range & Prototype & MW Prototype \\
\hline Small water-soluble compounds & $<500 \mathrm{Da}$ & Urea & 60 \\
Protein bound compounds & Mostly $<500 \mathrm{Da}$ & Indoxyl sulfate & 213.2 \\
Middle molecules & $\geq 500 \mathrm{Da}$ & $\beta_{2}$-microglobulin & 11.818 \\
\hline
\end{tabular}

MW: molecular weight; Da: Dalton.

For preparing this review, a list of all toxins worth discussing was prepared (Table 2) and then a literature search via PubMed was undertaken with as search terms the name of the toxin as mentioned in Table 2 on one hand AND toxin/toxicity, uraemic/uremic, CKD or biology, and the literature list was completed with references from previous review papers. Some toxins (e.g., the guanidines) were considered as a group, if in literature they were regularly discussed together. All relevant publications were retained, which implies that some of these point to no toxic effect or even a benefit. Whether the applied concentrations corresponded to those in uremia was not taken into account, as this implies a systematic review process [20]. This review was limited to organic solutes and will thus not deal with inorganic molecules (water, sodium, potassium, phosphorus).

Table 2. List of toxins considered in this publication per class.

\begin{tabular}{|c|c|c|}
\hline $\begin{array}{l}\text { Small } \quad \text { Water-Soluble } \\
\text { Compounds }\end{array}$ & Protein Bound Compounds & Middle Molecules \\
\hline Guanidine compounds & AGEs & Adrenomedullin \\
\hline -Guanidinosuccinic acid & AOPPs & Adiponectin \\
\hline -Methylguanidine & CMPF & Angiogenin \\
\hline -Guanidine & Cresols & Atrial natriuretic peptide \\
\hline -Creatine & -P-cresyl sulfate & $\beta_{2}$-microglobulin \\
\hline -Guanidino acetic acid & -P-cresyl glucuronide & $\beta$-endorphin \\
\hline$-\gamma$-Guanidino butyric acid & Hippurates & $\beta$-lipotropin \\
\hline -ADMA & -Hippuric acid & Cholecystokinin \\
\hline -SDMA & -P-hydroxy hippuric acid & Complement factor D \\
\hline Oxalate & -O-hydroxy hippuric acid & Complement factor $\mathrm{Ba}$ \\
\hline Phenylacetylglutamate & Homocysteine & Cystatin C \\
\hline Methylamines & Indoles & Interleukin-1 $\beta$ \\
\hline -(Mono)methylamine & -Indoxyl sulfate & Interleukin-18 \\
\hline -Dimethylamine & -Indoxyl glucuronide & Interleukin-6 \\
\hline -Trimethylamine & -Kynurenine & Tumor Necrosis Factor- $\alpha$ \\
\hline -Trimethylamine-N-Oxide & -Kynurenic acid & Interleukin-8 \\
\hline Sulfuric compounds & Phenols & Interleukin-10 \\
\hline -Lanthionine & -Phenyl sulfate & Endothelin \\
\hline Myoinositol & -Phenyl acetic acid & FGF-23 \\
\hline $2 \mathrm{PY}$ & Quinolinic acid & Ghrelin \\
\hline Polyamines & & Glomerulopressin \\
\hline -Acrolein & & Immunoglobulin light chains \\
\hline -Putrescine & & Lipids and lipoproteins \\
\hline -Spermine & & Leptin \\
\hline -Spermidine & & MCSF \\
\hline Urea & & Methionine-enkephalin \\
\hline Carbamylated compounds & & Neuropeptide $Y$ \\
\hline Cyanate & & Orexin A \\
\hline Ammonia & & Parathyroid hormone \\
\hline Uric acid & & Pentraxin-3 \\
\hline Xanthine & & Peptide YY \\
\hline \multirow[t]{4}{*}{ Hypoxanthine } & & Prolactin \\
\hline & & Resistin \\
\hline & & Retinol Binding Protein \\
\hline & & Visfatin \\
\hline
\end{tabular}

ADMA: Asymmetric Dimethylarginine; SDMA: Symmetric Dimethylarginine; 2PY: N-Methyl-2-Pyridonecarboxamide; AGEs: Advanced Glycation End Products; AOPPs: Advanced Oxidation Protein Products; CMPF: 3-Carboxy-4-Methyl-5-Propyl-2- Furanpropionic Acid; FGF-23: Fibroblast Growth Factor 23; MCSF: Macrophage Colony Stimulating Factor. 
We also constructed comprehensive tables with the most important biological effects and attributed per toxin a score for the evidence of toxicity (Table 3), whereby arguments in favor of toxicity from experimental or observational studies and randomized controlled trials were taken into account, with a counterbalance if there were also arguments for a neutral or beneficial effect. The scoring system was designed before the literature search was started to avoid bias and to preserve objectivity.

Table 3. System applied for scoring evidence.

\begin{tabular}{lc}
\hline \multicolumn{1}{c}{ Characteristic } & Points \\
\hline $1-2$ experimental studies showing toxicity & 1 \\
$>2$ experimental studies showing toxicity & 2 \\
$\geq 25 \%$ of retrieved experimental studies showing no toxicity or benefit & -1 \\
$1-2$ clinical studies* showing association with hard outcomes ** & 1 \\
$>2$ clinical studies* showing association with hard outcomes ** & 2 \\
$\geq 25 \%$ of retrieved clinical studies* showing no association with hard outcomes ** or benefit & -1 \\
\hline
\end{tabular}

* Observational studies and Randomized Controlled Trials (RCTs); ${ }^{* *}$ Hard outcomes: mortality, cardio-vascular events, progression of CKD.

It is acknowledged that the highest clinical level of evidence is obtained from randomized controlled trials (RCTs). However, for most of the toxins considered in this review, randomized controlled trials to check their toxicity are impossible because there are no methods to selectively decrease their concentration. In addition, for the few toxins for which selective concentration decrease is possible (uric acid, homocysteine, Advanced Glycation End products), the few RCTs gave sometimes ambiguous results. Therefore, it was decided not to consider RCTs separately in our scoring system but to account for them together with the observational studies under the common denominator of "clinical studies."

The scores for number of affected systems and evidence level were compared per uremic toxin group using a non-parametric one-way ANOVA followed by a parametric unpaired $t$-test (GraphPadPrism 5.01 Software, San Diego, CA, USA). $p<0.05$ was considered as significant.

\section{Small Water-Soluble Compounds}

The upper molecular weight limit for small water-soluble compounds has arbitrarily been defined as 500 Dalton (Da) (Table 1) and according to their definition protein binding should be minimal. Complete lack of protein binding cannot be excluded but in general should be negligible so as to have no influence on their removal by dialysis, which is efficient with any type of dialysis, although in some cases hampered by kinetic characteristics [21]. Although this removal is dependent on dialyzer blood and dialysate flow and surface area, those characteristics cannot be increased indefinitely to enhance adequacy and therefore probably other approaches such as longer or more frequent dialysis or adsorption should be considered [22].

To the best of our knowledge, the last review on the small water-soluble compounds was published more than 10 years ago [23].

\subsection{Guanidines}

Guanidines are widely spread in nature and a considerable number of compounds is present in humans and retained in uremia $[1,5]$. The biologic impact of this group of compounds has been demonstrated since many years and the first studies focused on their neurotoxicity, showing their contribution to uremic epiphenomena such as neuroexcitation and impaired cognition, activity and exploratory social behavior [24-27]. Later studies suggested that the guanidines might also be involved in other uremic complications such as inflammation and inhibition of endothelial cell proliferation, decreased osteoblast calcification and increased osteoclastogenesis [28,29]. Guanidino succinic acid suppresses calcitriol synthesis [30]. 
Analogous to advanced glycation (see below), guanidines can also promote post-translational protein modification, which has the potential to alter biological function of those proteins [31].

In spite of an origin analogous to that of urea and a molecular weight in the same range, kinetic and removal pattern of the guanidines during dialysis differs significantly from that of urea [21,32].

Asymmetric and Symmetric Dimethylarginine (ADMA and SDMA) are two guanidines with specific biological characteristics [23] that will be discussed separately below.

\subsubsection{Asymmetric Dimethylarginine (ADMA)}

ADMA has since 1992 been identified as a uremic retention compound with potential hemodynamic impact because it inhibits nitric oxide synthase (NOS), hence decreasing the endothelial protective effect of nitric oxide (NO) $[33,34]$. Of note, ADMA concentration is increased in a host of settings, many of which are linked to CKD, such as diabetes mellitus, obesity or various forms of cardio-vascular disease [35]. However, it is not always clear whether in the studies identifying high ADMA values in these conditions adjustments for kidney function have been made [35]. ADMA concentration has been linked to cardio-vascular events or mortality in the general population [36,37], as well as in CKD [38,39].

The rise in concentration of ADMA in CKD can to a large extent be attributed to a decreased activity of the enzyme dimethylarginine dimethylaminohydrolase (DDAH), which is responsible for the breakdown of ADMA, rather than to a direct decrease of urinary excretion $[18,40]$.

In healthy volunteers, it was shown that infusing ADMA up to concentrations relevant for uremia had definite hemodynamic effects [41]. Although several attempts have been made to decrease ADMA concentration by drugs or other approaches affecting their metabolism, no indisputable removal method has been identified [35]. Renal denervation in resistant hypertensive patients could decrease ADMA, pointing to the important effect of sympathetic nerve function on its generation [42].

With regards to biologic effects that are of relevance to the uremic condition, ADMA has been linked to polymorphonuclear activation, increased myeloperoxidase release and superoxide production [40,43], expression of adhesion molecules [29] and neurologic alterations such as depression and cognitive disturbances [43,44]. Observational clinical studies as well as experimental studies in wild type CKD mice and in transgenic mice overexpressing DDAH in spite of CKD, suggested also a role in erythropoietin resistance [45]. ADMA levels were also strongly correlated to fibrinogen levels, even at multivariate analysis [38]. Finally, overexpression of DDAH also protected against coronary artery disease in mice with a cardiac graft [46].

\subsubsection{Symmetric Dimethylarginine (SDMA)}

SDMA is an isomer of ADMA [34] that for a long time has been considered biologically inert [33]. However, during the last decade a number of studies showed that also SDMA was biologically active [18]. First, in endothelial cells, SDMA appeared to decrease NO production, be it via a competition for the NOS substrate, L-arginine, whereas reactive oxygen species (ROS) production was increased $[47,48]$. In a comprehensive analysis of toxic effects, SDMA appeared to induce inflammation via a broad array of mechanisms essentially affecting leukocytes [29]. Finally, SDMA was detected in uremic High Density Lipoprotein (HDL), transforming HDL into an abnormal lipoprotein inducing endothelial damage [49].

On the clinical level, SDMA was more significantly correlated to serum inflammatory markers than ADMA [48] and it also correlated to mortality and cardio-vascular events in a post-hoc analysis of the Hemodialysis (HEMO)-study, be it to a lesser extent than ADMA did [39]. In the general population, SDMA was associated with mortality, even after adjustment for multiple cardiovascular risk factors, including CKD [50,51]. In the latter two studies, SDMA was a stronger predictor than ADMA [50,51]. Like ADMA, also SDMA could be decreased by renal denervation [42]. 
In spite of the structural analogies with ADMA, SDMA is not dependent on DDAH for its clearance from the body [34] as it is largely removed by renal excretion [18], with a highly significant correlation with eGFR [47].

\subsection{Oxalate}

Next to the severe oxalate depositions in genetically conditioned primary hyperoxaluria [52], also kidney failure of any cause is associated with tissue depositions of oxalate [53], which can be attributed to supersaturation of serum with oxalate, especially in advanced CKD and dialyzed patients [54]. Very few studies have however assessed the biological impact of oxalate at uremic concentrations. In endothelial cells, oxalate resulted in an increase of intracellular calcium [55], leading to disturbed endothelial proliferation and repair $[55,56]$. Oxalate also decreases glucuronidation, a detoxifying conjugation process [57].

\subsection{Phenylacetylglutamate}

Phenylacetylglutamate has since long been recognized as a uremic retention product [58] generated by the intestinal microbiota [8]. In recent observational studies the compound has been associated to clinical outcomes relevant to uremia and CKD, such as first cardiovascular event in hemodialysis patients [59], overall mortality and cardio-vascular disease in CKD stages 1-5 [60] and cognitive dysfunction in patients receiving dialysis [61]. To the best of our knowledge, however, it has not been shown whether this compound exerts any direct biological impact. Under certain conditions, it even seems beneficial and an anti-proliferative effect on cancer cells has been demonstrated [62]. Thus, whether phenylacetylglutamate is a real uremic toxin or merely a marker of retention remains for the time being unresolved.

\subsection{Methylamines}

The methylamines (monomethylamine-MMA, dimethylamine-DMA and trimethylamineTMA) are since long known as uremic retention solutes and may be held responsible for some aspects of malodorous uremic breath [63]. Experimental data on the biological effect of these compounds are very scanty. Preliminary data suggested at least for trimethylamine a link to neurobehavioral disturbances [64]. Methylamine turnover has been associated to vulnerability to atherosclerosis in mice [65]. Dimethylamine and trimethylamine are inhibitors of the organic cation transporter 2 (OCT2), which plays a role in the renal secretion of drugs [66].

In an observational outcome study in hemodialysis patients, methylamine and dimethylamine were however not related to all-cause mortality [67]. On the other hand, monomethylamine has been associated with olfactory dysfunction in hemodialysis patients [68].

Also, trimethylamine-N-Oxide (TMAO) was known as a component of uremic biological fluids [69] already before a boost in studies on this solute occurred from 2011 on when Wang et al. suggested a substantial link to cardio-vascular disease [70]. Its association to CKD and its patho-physiologic role based on experimental and clinical data, are discussed extensively in an article of this special issue [71].

Intriguingly, in spite of the substantial number of data supporting the toxicity of TMAO [71] (Figure 2B, Supplementary Materials Table S1), the compound is also known as a stabilizer of protein structures [72]. Equally paradoxical, fish as a notorious source of TMAO is protective to cardiovascular disease [73]. 

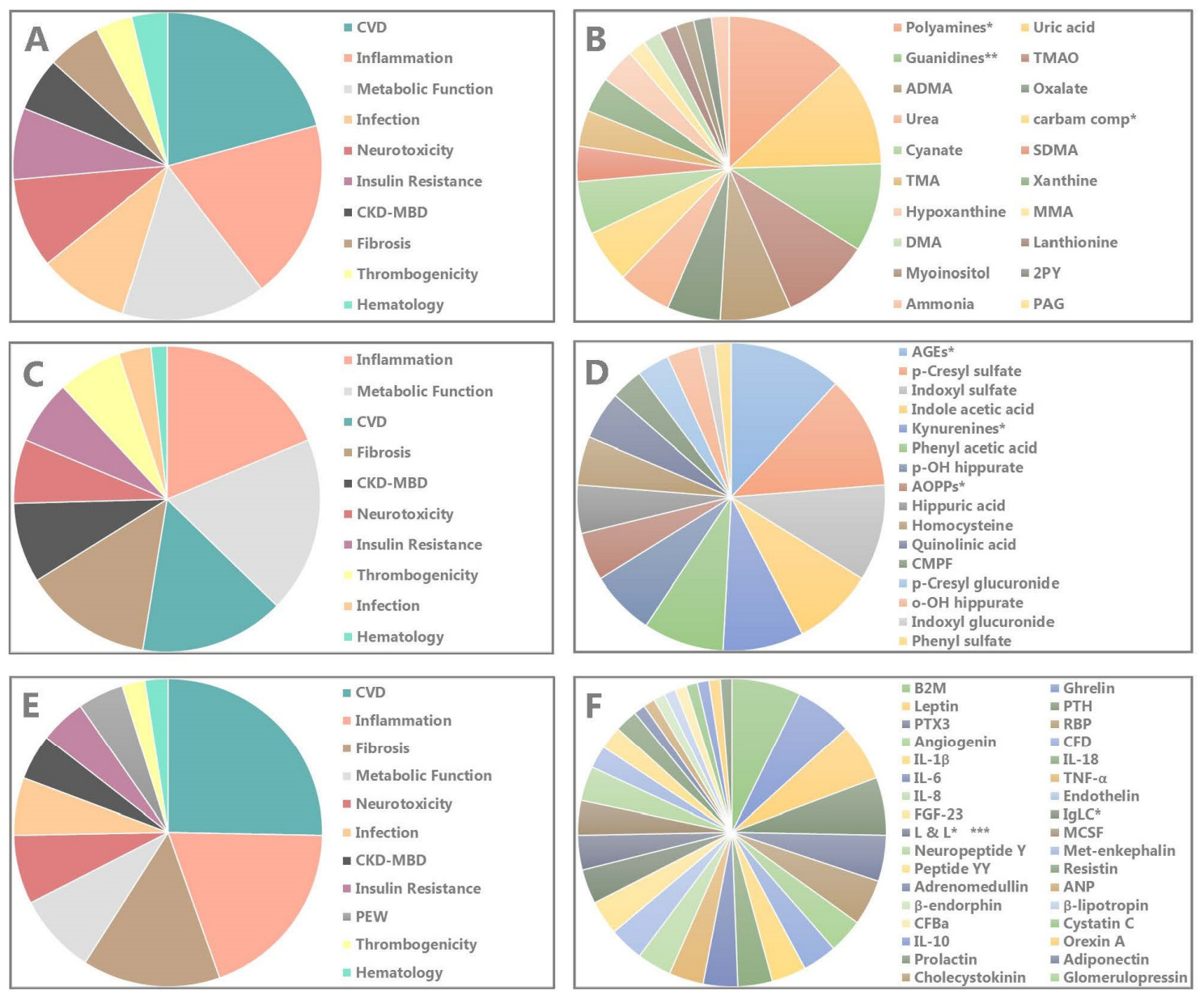

Figure 2. Number of toxins within a group affecting specific systems (left-panels $(\mathbf{A}, \mathbf{C}, \mathbf{E})$ ) and number of systems affected by each individual toxin (right, panels $(\mathbf{B}, \mathbf{D}, \mathbf{F})$. Small water-soluble compounds (above, panels (A,B)), protein bound compounds (middle-panels (C,D) and middle molecules (below-panels $(\mathbf{E}, \mathbf{F})$ ). The systems and solutes are ranked clockwise from $12 \mathrm{~h}$ on, in proportion to the number involved, the largest numbers coming first. Abbreviations-CVD: cardiovascular disease; CKD-MBD: chronic kidney disease-metabolic bone disease; PEW: protein energy wasting; ADMA: Asymmetric Dimethylarginine; TMA: Trimethylamine; DMA: Dimethylamine; TMAO: Trimethylamine-N-Oxide; carbam comp: carbamylated compounds; SDMA: Symmetric Dimethylarginine; MMA: Monomethylamine; 2PY: N-Methyl-2-Pyridone-carboxamide; PAG: Phenylacetylglutamine; AGEs: Advanced Glycation End Products, p-OH hippurate: p-hydroxyhippurate; AOPPs: Advanced Oxidation protein Products; CMPF: Carboxy Methyl Propyl Furanpropionic Acid; o-OH hippurate: o-hydroxyhippurate; $\beta 2 \mathrm{M}$ : $\beta_{2}$-microglobulin; PTX-3: pentraxin-3; IL-1 $\beta$ : Interleukin-1 $\beta$; IL-6: interleukin-6; FGF-23: Fibroblast Growth Factor-23; L \& L: lipids and lipoproteins; CFBa: Complement Factor Ba; IL-10: Interleukin-10; PTH: Parathyroid Hormone; RBP: Retinol Binding Protein; CFD: Complement Factor D; IL-18: Interleukin-18; TNF- $\alpha$ : Tumor Necrosis Factor- $\alpha$; IgLC: Immunoglobulin Light Chains; Met-Enkephalin: Methionine-Enkephalin; MCSF: Macrophage Colony Stimulating Factor; ANP: Atrial Natriuretic"Peptide.; * polyamines, carbamylated compounds, AGEs, AOPPs, kynurenines, Immunoglobulin Light Chains and lipids and lipoproteins (modified) considered as one group; ** guanidines considered as one group with the exception of ADMA and SDMA ; *** modified-post-translational. 


\subsection{Sulfur-Containing Compounds}

Whereas a significantly increased exhalation of organic sulfated gases has been observed in uremia [74], a deficiency of the inorganic gas $\mathrm{H}_{2} \mathrm{~S}$ also has been observed [75]. $\mathrm{H}_{2} \mathrm{~S}$ is generally considered to be vasculoprotective [76,77], thus its deficiency may contribute to uremic vascular disease [78]. Homocysteine is a sulfur-containing uremic retention solute that will be discussed below in the section on protein-bound solutes. Also, lanthionine is a sulfur-containing compound with probably no substantial protein-binding which has been shown to inhibit $\mathrm{H}_{2} \mathrm{~S}$ production [75]. Lanthionine is discussed extensively in one of the reviews of this special issue [79].

\subsection{Myoinositol}

Myoinositol concentration is increased in cauda equina of uremic patients as compared to healthy controls [80]. Sciatic nerve conduction velocity was decreased in rats treated with myoinositol [81]. Myoinositol also inhibits the proliferation of Schwann cells [80]. In spite of these early data suggesting a role in uremic neurotoxicity, subsequent direct assessments of the impact of myoinositol on nervous function could not confirm this effect [25,82] and some studies even suggest a neuroprotective effect [83].

\subsection{N-Methyl-2-Pyridone-5-Carboxamide (2PY)}

2PY has since long been recognized as a uremic retention solute [1] with a potential of toxicity by inhibition of poly(ADP-ribose) polymerase-1 (PARP-1), an effect possibly impairing DNA replication and repair $[84,85]$. The interest in this compound was recently boosted by its manifold increase in concentration in CKD patients receiving nicotinamide to attenuate hyperphosphatemia [86]. In a comparative study of nicotinamide with sevelamer, drop-out due to adverse events was $60 \%$ higher with nicotinamide, whereby it has been hypothesized that this effect could in part have been due to 2PY [86]. All relevant aspects regarding this compound are elegantly reviewed in this special issue [85] and its experimental and clinical impact is further summarized in Table 4 and Supplemental Table S1.

Table 4. Summary of evidence data available on the small water-soluble compounds.

\begin{tabular}{|c|c|c|c|c|c|}
\hline Type of Evidence Points & Exp. Toxic. 1-2 & $\begin{array}{l}\text { Exp. Neutral } \\
\text { or Benefit -1 }\end{array}$ & Clin. Toxic. 1-2 & $\begin{array}{l}\text { Clin. Neutral } \\
\text { or Benefit -1 }\end{array}$ & Sum 4 (max) \\
\hline Guanidines * & 2 & 0 & 0 & 0 & 2 \\
\hline ADMA & 2 & 0 & 2 & 0 & 4 \\
\hline SDMA & 2 & 0 & 2 & 0 & 4 \\
\hline Oxalate & 2 & 0 & 0 & 0 & 2 \\
\hline PAG & 0 & -1 & 2 & 0 & 1 \\
\hline MMA & 1 & 0 & 0 & -1 & 0 \\
\hline DMA & 1 & 0 & 0 & -1 & 0 \\
\hline TMA & 2 & 0 & 0 & -1 & 1 \\
\hline TMAO & 2 & 0 & 2 & -1 & 3 \\
\hline Lanthionine & 1 & 0 & 0 & 0 & 1 \\
\hline Myoinositol & 1 & -1 & 0 & 0 & 0 \\
\hline $2 \mathrm{PY}$ & 1 & 0 & 0 & 0 & 1 \\
\hline Polyamines ** & 2 & 0 & 0 & 0 & 2 \\
\hline Urea & 2 & 0 & 0 & 0 & 2 \\
\hline Carbamylated compounds ** & 2 & 0 & 2 & 0 & 4 \\
\hline Cyanate & 2 & 0 & 0 & 0 & 2 \\
\hline Ammonia & 1 & 0 & 0 & 0 & 1 \\
\hline Uric acid & 2 & 0 & 2 & -1 & 3 \\
\hline Xanthine & 1 & 0 & 0 & 0 & 1 \\
\hline Hypoxanthine & 1 & 0 & 0 & 0 & 1 \\
\hline
\end{tabular}

Exp.: experimental; clin.: clinical (observational + Randomized Controlled Trials-RCTs); Toxic.: Toxicity; ADMA: Asymmetric Dimethylarginine; SDMA: Symmetric Dimethylarginine; PAG: Phenylacetylglutamine; MMA: Monomethylamine; DMA: Dimethylamine; TMA: Trimethylamine; TMAO: Trimethylamine-N-Oxide; 2PY: N-Methyl-2-Pyridone-carboxamide; * guanidines treated as one group, with the exception of ADMA and SDMA; ** polyamines and carbamylated compounds considered as one group. 


\subsection{Polyamines}

Although the toxicity of the polyamines has been studied extensively, especially at the end of previous century, interest has somewhat waned during more recent years.

Several structurally related polyamines such as spermine, spermidine, putrescine and cadaverine, may be retained in uremia [1]. Most experimental toxicity data (summarized below) have been accumulated with spermine and spermidine. On the other hand, it has been hypothesized that the previously argued toxicity of especially spermine may be attributed to its oxidative product, acrolein [87] that appears in uremia and uremic samples at the expense of spermine by the activity of the enzyme amine oxidase $[88,89]$. Recent data indeed show a decrease rather than an increase of concentration in CKD, especially for spermine and spermidine $[5,88]$. Some of these polyamines may be conjugated to proteins [90].

One of the first biological effects of this group of solutes to be described in the context of uremia, was an inhibition of erythropoiesis [91-93]. Polyamine-protein conjugates accumulate in plasma of hemodialysis patients and reduce erythropoiesis via inhibition of mononuclear bone marrow cell proliferation [90]. Spermine also inhibited NOS induction in activated macrophages, which may contribute to deficient immune response [94], while it induced oxidative stress in smooth muscle cells, reducing intracellular glutathione and impairing glucose metabolism [95]. Several polyamines inhibited platelet aggregation [96].

Neurotoxicity of polyamines has repeatedly been assessed. In the earliest studies, this effect was attributed to interference with the N-Methyl-D-aspartate (NMDA) receptor which plays a crucial role in channel conductance, leading to neuronal death and neuroexcitation [25,97-99]. However, polyamines also play a role in neurotoxicity via other mechanisms, such as NMDA-receptor independent death of neuronal cells [100,101] or interaction with calcium channels [25].

Putrescine inhibits in vitro cell growth of fibroblast-like cells and alters their mitochondrial, cytoplasmic and nuclear membrane structures [102]. Spermine cytotoxicity has also been linked to changes in mitochondrial calcium transport in non-neuronal tissue types such as liver, pancreas and heart $[103,104]$. The effect on pancreas may play a role in decreasing insulin sensitivity [104]. Finally, in immortalized renal tubular cells several of the polyamines inhibited activity of OCT expression [105].

Of note, some studies also showed beneficial effects, such as improvement of ganglion cell survival and of optic nerve regeneration [106], neuroprotection in brain damage [107] and free radical scavenging [108]. Although those studies in general were not undertaken with uremic toxicity in mind, they might support the hypothesis that the toxicity observed with polyamines is rather generated by metabolites like acrolein [87].

\subsection{Urea and Derivatives}

Urea, a marker of uremic retention in CKD and of adequacy of intra-dialytic solute removal, has traditionally been considered to be biologically inert [109]. However, a number of recent experimental data suggest that urea is toxic at concentrations representative for CKD [110-112]. First of all, at least five studies indicate that urea itself directly induces molecular changes related to insulin resistance [113,114], free radical production [113-115], apoptosis [116] and disruption of the protective intestinal barrier [117]. Urea also generates cyanate, ammonia and via cyanate carbamylated compounds which as such all have been linked to biological changes (see below). The findings above may increase the patho-physiological underpinning for the validity of $\mathrm{KT} / \mathrm{V}_{\text {urea }}$ as a marker of dialysis adequacy. Yet, also the views that the kinetics of urea are not representative for those of several other uremic retention solutes and that this compound cannot be held responsible for all complex metabolic and clinical changes of the uremic syndrome still remain valid [109].

Increasing urea (and other solute) removal by raising $\mathrm{Kt} / \mathrm{V}_{\text {urea }}$ by more than $30 \%$ above standard in an RCT-setting [HEMO-study] could not improve patient outcomes [118] but the results may have been skewed in that study by the short dialysis times [119], which in the Dialysis Outcomes Practice Patterns Study (DOPPS)-analysis predict negative outcomes independently of $\mathrm{Kt} / \mathrm{V}_{\text {urea }}$ [120]. 
In addition, in a post hoc analysis of the HEMO data, the impact of the rise in $\mathrm{Kt} / \mathrm{V}_{\text {urea }}$ on pre-dialysis concentration of relevant uremic toxins was modest to absent $[119,121]$.

\subsubsection{Carbamylated Compounds}

The role of carbamylation in CKD has extensively been reviewed elsewhere [122]. Carbamylation is responsible for posttranslational protein modifications resulting in a similar biochemical process as when Advanced Glycation End Products (AGEs) are generated (see below). As they are derived from urea [122], we will discuss them here. Carbamylated compounds are involved in atherogenesis and other functional changes, such as activation of mesangial cells into a profibrogenic prototype, with a potential to play a role in the progression of kidney failure [123] and modification of leukocyte response to collagens [124]. Carbamylated LDL dose dependently induced endothelial cell death and smooth muscle cell proliferation [125] and an increase in monocyte adhesion to endothelium [126], vascular cell changes of relevance to atherogenesis. Also, high density lipoprotein (HDL) is carbamylated in CKD and inhibits endothelial repair function [127].

In at least 3 observational clinical studies focusing on independent hemodialysis populations carbamylated compounds were associated with cardiovascular events and overall and cardiovascular mortality [128-130].

\subsubsection{Cyanate}

Cyanate is a free radical in equilibrium with urea, with increased levels in CKD, as a consequence of the increased availability of urea [131]. Apart from its known link to carbamylation (see above), cyanate also exerts toxicity by itself. Incubation of coronary endothelial cells in the presence of cyanate decreased NOS expression and increased thrombogenic tissue factor and plasminogen activator inhibitor-1 expression [132]. Cyanate also dose-dependently decreased glucose sensitive insulin secretion by pancreatic islets, by a mechanism independent of that generated by urea [114].

\subsubsection{Ammonia}

Urea is converted to ammonia by urease which is expressed by a number of intestinal bacteria [133]. In vitro studies evaluating expression of intestinal epithelial tight junction proteins not only showed their depletion in the presence of urea but also an even more important decrease when urease, inducing ammonia generation, was added to the medium [117]. This mechanism may contribute to systemic inflammation of CKD by allowing endotoxin from the intestinal lumen to enter the blood stream.

\subsection{Purines}

\subsubsection{Uric Acid}

Uric acid has been associated with calcitriol metabolism and with inhibition of expression on monocytes of CD14, a lipopolysaccharide receptor [134-136].

More recently, uric acid has also been linked to pro-inflammatory processes in cells of the vascular wall, such as monocyte chemoattractant protein-1 (MCP-1) expression by vascular smooth muscle cell [137], induction of oxidative stress [138], renin angiotensin system stimulation and smooth muscle cell proliferation [139]. In human umbilical vein endothelial cells (HUVECs), uric acid induces insulin resistance and suppresses the generation of nitric oxide in response to insulin [140]. Genetic disruption of the uric oxidase gene in mice generated severe hyperuricemia and urate nephropathy [141]. In a series of rat experiments, induction of mild hyperuricemia caused systemic and glomerular hypertension, glomerular sclerosis and renal infiltration of macrophages [142]. All those mechanisms may contribute to hypertension, uremic vascular disease, progression of CKD and thus mortality [143].

In a longitudinal clinical analysis, uric acid was associated with CKD progression, especially in proteinuric patients, even after adjustment for confounders [144]. Uric acid concentration has 
been associated with parameters of vascular stiffness in participants of the Framingham study [145]. In the National Health and Nutrition Survey (NHANES) study, high uric acid was associated with overall and cardiovascular mortality but the association disappeared after correction for kidney function [146]. In a Mendelian randomization study, both uric acid itself as well as a score composed of a number of genetic polymorphisms associated to high uric acid were associated with multiple cardiovascular complications [147]. In a systematic review and meta-analysis of CKD-patients, uric acid levels were significantly associated with mortality, even after adjustment for kidney function [148]. Uric acid has also been associated with the incidence of acute ischemic stroke [149] and mild cognitive dysfunction [150]. However, in an observational analysis of hemodialysis patients from Taiwan included in this special issue, an inverse relation was found between uric acid concentration and mortality [151]. Similarly, in a large hemodialysis patient database, low and not high uric acid was associated to mortality, especially in those patients with low protein intake [152].

The major problem of observational clinical studies on the impact of uric acid is a risk of confounding as a number of factors commonly linked to elevated uric acid (obesity, diabetes, hypertension), are cardiovascular risk factors by themselves. Many studies adjust for several of those risk factors but residual confounding can never be excluded entirely.

Uric acid takes a unique position among the uremic retention solutes because it is one of the only compounds of which the concentration can be decreased selectively by specific medication, such as allopurinol or probenecid. In an observational study in CKD patients, treatment with allopurinol was associated with improved arterial stiffness, even after correction for confounders [153]. In a Japanese section of the DOPPS, allopurinol was associated with lower overall mortality in a subpopulation without previous cardiovascular events [154].

A few RCTs assessing the impact of uric acid lowering drugs on parameters of endothelial function showed no positive effect $[155,156]$. On the other hand, in a short-term study, allopurinol was shown to decrease blood pressure in young adolescents with newly diagnosed essential hypertension [157]. In another RCT, in CKD, the group treated with allopurinol had a lower number of cardiovascular events and a slower progression of kidney failure but the small sample size of the study was a limitation factor, so this study needs confirmation [158]. A decrease of uric acid by allopurinol was linked to a rise in serum calcitriol [135].

Thus, in spite of substantial arguments for the toxicity of uric acid, not all data are consistent, especially in RCTs applying uric acid decreasing drugs. In addition, it should be taken into account that the main currently available intervention to lower uric acid, allopurinol, has by itself a considerable complication profile, so that studies suggesting a positive effect should rather be considered as proof of concept than as an incentive for treatment, especially in asymptomatic hyperuricemia.

\subsubsection{Xanthine and Hypoxanthine}

Xanthine and hypoxanthine are two other purines that sporadically have been submitted to toxicity studies. Both compounds have been linked to inhibition of calcitriol synthesis [134,159] and of membrane linked expression of the lipopolysaccharide receptor, CD14, on monocytes [136].

\subsection{Summary}

Small water-soluble uremic retention solutes can no more be considered as irrelevant to the uremic syndrome, with an average number of affected systems in experimental studies of $2.65 \pm 1.89$. The systems affected by the largest number of toxins are cardiovascular disease $(n=11)$, inflammation $(n=10)$ and metabolic function $(n=8)$ (Figure 2A, Supplementary Materials Table S1), which all are pivotal for clinical condition and survival. The groups of toxins affecting the largest number of systems are the polyamines $(n=7)$ and the guanidines $(n=5)$. For the individual compounds these are uric acid $(n=6)$, TMAO $(n=5)$ and ADMA $(n=4)$ (Figure 2B, Supplementary Materials Table S1). However, with regard to some polyamines, there is debate on whether their concentration is increased or not [5] and whether they all are real toxins [87]. 
The average evidence score is $1.75 \pm 1.29$ (maximum possible $=4$ ). For this aspect, the list is headed by the carbamylated compounds for the groups $(\mathrm{n}=4)$ and by ADMA and SDMA $(\mathrm{n}=4)$ followed by TMAO and uric acid $(\mathrm{n}=3)$ for the individual compounds (Table 4$)$.

\section{Protein Bound Compounds}

The protein bound uremic toxins are a heterogeneous group of generally small solutes, which, due to their protein binding, are difficult to remove by dialysis. Their protein binding coefficient is in general low although some compounds may be more stable, especially those generated by posttranslational modifications, such as the advanced glycation end products (AGEs). Many of the protein bound solutes are generated by the intestine [160].

For the time being few therapeutic options exist that specifically can decrease the concentration of this group of solutes and one of these, the orally administered intestinal sorbent AST-120 (Kremezin ${ }^{R}$ ) did not impact progression of CKD in RCTs [161,162]. For some solutes, specific strategies exist to reduce the concentration of only this compound or group of compounds (e.g., folic acid for homocysteine) and those strategies will be discussed specifically in the subheadings devoted to those molecules.

To the best of our knowledge, the last review considering a large array of protein bound uremic toxins was published almost 10 years ago [163]. After that, reviews have been restricted to specific toxins (e.g., indoxyl sulfate, p-cresyl sulfate) $[20,164,165]$, probably due to the overwhelming number of novel research data.

\subsection{Advanced Glycation End Products (AGEs)}

The role of AGEs in CKD has been reviewed extensively elsewhere [166]. AGEs are generated by the reaction of specific amino acids within the protein structure (both complete proteins and protein degradation products) with the carbamyl group of reducing sugars, which is then stabilized by oxidation. AGE compounds and their precursors are numerous and contain $N$-carboxymethyllysine, pentosidine, hydroxyimidazolone, 3-deoxyglucosone, malondialdehyde, pyrraline, glyoxal and methylglyoxal. AGE accumulation has first been identified in diabetes mellitus [167]. Because CKD as a condition is characterized by inflammation, oxidation as well as retention, AGE accumulation is a typical feature of CKD [168], irrespective of diabetic status [169].

AGEs bind to a number of receptors, among which advanced glycation end product-specific receptor (RAGE) plays a central role to impose several deleterious biological effects $[170,171]$. RAGE expression is increased in many inflammatory conditions [172] and also in CKD [173,174].

AGEs have a negative impact on body functions and overall outcomes via several mechanisms, among which induction of oxidative stress [175], inflammation [176-178] and endothelial dysfunction [178-180] including quenching of NO [179], are the most prominent. AGEs have also been linked to thrombogenicity [181], kidney fibrosis [182], structural bone damage [183] and neurotoxicity [184].

With all these functional alterations, it is no surprise that on a more global organic level, AGEs are linked to vascular stiffness, damage and calcification [185-187].

Studies on the links between AGEs and mortality gave conflicting results, with some studies even showing better outcomes with higher AGE levels [188,189]. Such results may reflect confounding factors such as better nutritional status resulting in both higher AGEs and higher survival, or the index AGE may have been a compound with low biological impact or with lower vital tissue concentration. In contrast, low serum soluble RAGEs, which are actors protecting against AGE activity, have consistently been linked to cardiovascular risk factors and events [190].

Many interventional attempts have been made to reduce AGE levels either by extracorporeal or by drug treatment. Among the removal strategies high efficiency low pro-inflammatory dialysis options generally turned out to be most efficient but were in general not efficient enough to induce substantial decreases in concentration [191-193]. AGE-restricted diet may help to reduce their concentration [194]. 
None of the tested pharmaceutical options has currently emanated in approved therapies for clinical use [166]. One of the most recent acquisitions is glyoxylase-1 induction, which in pilot studies in obese subjects resulted in the breakdown of methylglyoxal, improved glycemic control, an increase in insulin sensitivity and better vascular function [195,196].

\subsection{Advanced Oxidation Protein Products (AOPPS)}

Similar to AGEs, also AOPPs are posttranslational protein modifications (of both complete proteins and protein degradation products) induced by oxidative stress [197,198]. Both AOPPs prepared in vitro and extracted from plasma of hemodialysis patients have been linked to pro-inflammatory mechanisms, such as induction of oxidative metabolism of leukocytes [198] and free radical production by fibroblasts and endothelium in a setting of scleroderma [199].

Although it has been suggested that their concentration progressively increases throughout CKD to reach a maximum in hemodialysis patients [200] and that these concentrations were predictive of subsequent cardiovascular events [201], concentration measurements are confounded by co-registration of other factors with cardiovascular impact such as triglycerides [202]. Yet, the toxic potential of AOPPs in uremia is less a matter of debate. Of note, RAGE not only interact with AGEs but also with AOPPs, suggesting that many oxidant products interact through the same signal pathways [203].

In this special issue, Garibaldi et al. demonstrate that AOPPs generate transition of macrophages into dendritic cells and an increase of their ROS production, which are key mechanisms in atherogenesis [204].

\subsection{Carboxy-Methyl-Propyl-Furanpropionic Acid (CMPF)}

3-carboxy-4-methyl-5-propyl-2-furanpropionic acid (CMPF), a urofuranic fatty acid, is a strongly lipophilic uremic solute and a major inhibitor of drug protein binding [205]. Next to drugs, it also decreases protein binding of natural metabolites such as thyroxine [206] and bilirubin [207], potentially increasing their biologic/toxic impact. This solute inhibits the renal uptake of p-amino hippuric acid (PAH) in rat kidney cortical slices [208] and competes for renal excretion against various drugs, metabolites and endogenously produced organic acids [209]. CMPF also inhibits hepatic glutathione-S-transferase [210], deiodination of T4 by cultured hepatocytes [211], hepatic digoxin clearance [212] and adenosine diphosphate (ADP)-stimulated oxidation of nicotinamide adenine dinucleotide (NADH)-linked substrates in isolated mitochondria [213]. There is a correlation between neurologic abnormalities and the plasma concentration of CMPF [214]. More recently, CMPF has been associated with inhibition of insulin secretion by pancreatic islets $[215,216]$. However, in vivo, no correlation between CMPF and parameters of glucose intolerance was found in subjects with features of the metabolic syndrome [217].

Since CMPF is virtually 100 percent protein bound, its removal by hemodialysis strategies is nonexistent but CMPF levels may be lowered with peritoneal dialysis [218]. Since this compound, as several other organic acids, is excreted by the renal tubules [219], enhancing excretion via this mechanism may help to reduce their concentration.

\subsection{Cresols}

\subsubsection{P-Cresyl Sulfate}

The mother compound of the cresols, p-cresol, was for a long time believed to be a major uremic toxin [220] but later on this point of view was shown to be the result of an artifact [221]. According to two almost simultaneous studies, the real major cresols retained in uremia were the conjugates p-cresyl sulfate and p-cresyl glucuronide [222,223]. Soon after this observation, the exploration started of the biological effect of the conjugate with the highest concentration, p-cresyl sulfate. This resulted in extensive data on its toxicity, summarized in a review article in this special issue [164]. 


\subsubsection{P-Cresyl Glucuronide}

P-cresyl glucuronide has far less extensively been studied than p-cresyl sulfate. Although its total concentration is markedly lower than that of p-cresyl sulfate, free "active" concentration is similar [221]. In contrast to p-cresyl sulfate, p-cresyl glucuronide as such has no activating impact on white blood cells but, when added to p-cresyl sulfate, it has an additive effect on leukocyte free radical production [19]. P-cresyl glucuronide also inhibits mitochondrial respiration and the activity of renal glucuronyltransferases [57]. In contrast to p-cresyl sulfate, $\mathrm{p}$-cresylglucuronide did however not trigger insulin resistance and metabolic disturbances [224].

In a longitudinal outcome study in a population with CKD and after adjustment for confounders, including eGFR, p-cresyl glucuronide showed a similar correlation to overall and cardiovascular mortality as indoxyl sulfate and p-cresyl sulfate, suggesting a comparable impact on mortality [225].

\subsection{Hippurates}

\subsubsection{Hippuric Acid}

Hippuric acid is since long known as an inhibitor of drug protein binding [226] but other biological effects have been less extensively explored. The compound has been associated with kidney damage and to proximal tubular injury [227-229], an effect related to organic acid transporter uptake [228]. Of note, also several metabolomic studies linked hippuric acid to renal tubular damage [230-232]. The only other toxic effects that were described were an inhibition of glucose utilization [233] and a decrease of digoxin uptake by hepatic cells [212].

\subsection{2. p-Hydroxyhippuric Acid}

p-Hydroxyhippuric acid induced free radical production in renal tubular cells [228], inhibition of tubular cell proliferation [228] and inhibition of $\mathrm{Ca}^{++}$-ATPase, possibly contributing to uremic bone disease, disturbed $\mathrm{Ca}^{++}$homeostasis and hypertension [234]. A similar effect of disturbed cellular $\mathrm{Ca}^{++}$efflux had previously been described in uremic plasma filtrate but that study had not been able to unravel the responsible solute(s) [69]. p-Hydroxyhippuric acid also attenuates leukocyte apoptosis, which may result in a pro-inflammatory effect [235].

\subsection{3. o-Hydroxyhippuric Acid}

Also, o-hydroxyhippuric acid induced free radical production in renal tubular cells and inhibition of tubular cell proliferation [228].

\subsection{Homocysteine}

Homocysteine (Hcy) is a sulphur-containing amino acid produced by demethylation of methionine and a cardiovascular risk factor in the general population. Its concentration is markedly increased in end stage kidney disease (ESKD) [236]. Retention in uremia results in the cellular accumulation of S-adenosyl homocysteine (AdoHcy), an extremely toxic compound that competes with S-adenosyl-methionine (AdoMet) and inhibits methyltransferases [237], a mechanism disturbing epigenetic control of gene expression by provoking DNA hypomethylation [238].

Hcy increases the proliferation of vascular smooth muscle cells, one of the most prominent hallmarks of atherosclerosis [239]. The administration to rats of excess quantities of the Hcy precursor, methionine, induces atherosclerosis-like alterations in the aorta [240]. Hcy also disrupts several vessel wall-related anticoagulant functions, potentially resulting in enhanced thrombogenicity [241].

More recent data have shown that hyperhomocysteinemia also is linked to a decreased concentration of hydrogen sulfide $\left(\mathrm{H}_{2} \mathrm{~S}\right)$, a volatile vasorelaxant [242] and to the increased generation of lanthionine, a condensate of two homocysteine molecules, which in its turn decreases $\mathrm{H}_{2} \mathrm{~S}[75,79]$. 
Serum homocysteine levels not only depend on kidney function but also on genetic predisposition [243] and vitamin status [244]. Homocysteine levels can be reduced by the administration of folic acid, vitamin B6 and/or vitamin B12 [245,246]. CKD patients may be refractory to regular folate doses as applied to the general population and may require higher quantities than the non-uremic population.

When analyzing the relation between homocysteine levels and hard outcomes in CKD, two large, observational studies concluded that low rather than high homocysteine levels were associated with poor outcomes $[189,247]$ but potential confounders are the frequent inflammatory and malnourished status of CKD patients. Along this line of thought, one study demonstrated that homocysteine was directly related to mortality in that part of a hemodialysis population that did not suffer from a chronic inflammation-malnutrition state (CISM) [248]. This relationship was masked in patients with CISM [248]. Another carefully conducted analysis, however, found no association between total homocysteine and cardiovascular disease risk [249].

In four RCTs in CKD vascular events or fatal outcomes were not reduced by homocysteine lowering therapies with administration of folic acid alone or combined to other B vitamins [250-253]. However, in all but one of these studies the control patients had been subjected to folic acid fortification in regular food [250-252].

A sub-analysis of a large RCT on the effect of folic acid on stroke in a large population of hypertensive Chinese [254], showed in the subgroup with CKD, that folic acid combined to enalapril more efficiently refrained progression of CKD than enalapril alone [255]. This study obviated the bias of folic acid fortification in the general population but on the other hand was restricted to hypertensive Chinese, which might have implied specific genetic or metabolic factors.

Two meta-analyses suggested a reduction of cardiovascular disease associated with the application of homocysteine lowering preparations in CKD [256,257]. This effect was seen especially in subpopulations that were not or only partially subject to folic acid food fortification, or that showed a decrease of homocysteine by more than $20 \%$ in the treated group, irrespective of folic acid fortification [257]. Many studies in these meta-analyses were small, which might have detracted from the credibility of the analysis.

Dialytic removal of homocysteine is thought to be hampered in a similar way as for the other protein bound uremic toxins. Dialysis with a membrane with very large pores could decrease homocysteine concentrations, possibly due to a modification of metabolism, rather than to direct removal [258].

Thus, attempts to study the impact of homocysteine concentration on cardiovascular outcomes emanated in conflicting results but some of these studies might be subjected to confounding. On one hand, observational studies may have been confounded by malnutrition and inflammatory status. On the other, controlled studies with vitamin B preparations may have been confounded by folic acid fortification in the general population. However, clinical data seem too conflicting to offer convincing arguments about the role of homocysteine in CKD, possibly because its impact is, in contrast to the general population, overridden by the toxic effect of other solutes.

\subsection{Indoles}

Several of the indoles, which are tryptophan metabolites, are retained in CKD. Also, quinolinic acid, although not properly considered as an indole, is a tryptophan metabolite (see below).

\subsubsection{Indoxyl Sulfate}

Indoxyl sulfate has in the context of uremic toxicity definitely been the most extensively studied of all indoles. Although there has been debate whether in those studies the correct concentrations were used [259], a systematic review found a substantial number of studies applying the right conditions [20]. Clinical evidence of toxicity in humans however is only observational and several studies showed no association [165]. This special issue contains an extensive review on the toxicity of indoxyl sulfate [165] 
with an addition to this review in a letter to the editor [260]. This special issue also contains a publication describing an oxidative effect and inhibition of nitric oxide in endothelial cells by indoxyl sulfate that is counteracted by uric acid [151] and two other studies respectively assessing the role of indoxyl sulfate in inhibiting neovascularization [261] and in enhancing coagulation [262].

\subsubsection{Indole Acetic Acid}

Indole acetic acid in general received less attention in uremia research than indoxyl sulfate but this trend has changed especially during the last few years. Indole acetic acid has been linked to cardiovascular disease by induction of pro-inflammatory mechanisms $[263,264]$ and pro-coagulant tissue factor production [265]. Like for indoxyl sulfate, these effects to a large extent are linked to the activation of the Aryl Hydrocarbon Receptor (AhR) that seems to play a central role in the biological action of several indoles [266].

Indole acetic acid also induces proximal tubular injury after uptake via organic acid transporters, stimulates cellular free radical production [228] affecting cell viability [229] and accelerates progression of CKD in experimental animal studies [227]. Furthermore, indole acetic acid has been linked to a number of metabolic effects, such as the inhibition of uptake of digoxin [212] and renal glucuronidation [57].

In one study indole acetic acid had no pro-oxidant effect [267] but this compound may need to be oxidized to become biologically active, as suggested by a study in a hematological malignancy setting, showing a cytotoxic effect of oxidized indole acetic acid [268].

In an observational clinical study, indole acetic acid was associated with increased mortality and cardiovascular events [263].

\subsubsection{Indoxyl Glucuronide}

Although it is known since some years that also indoxyl- $\beta-\mathrm{d}-$ glucuronide is retained in uremia [269], arguments in favor of a biological effect are scanty. Indoxyl glucuronide is one of the uremic solutes inhibiting the OCT2, which plays a role in the renal secretion of drugs [66].

\subsection{Kynurenines}

Elements of the kynurenic pathway are increased in CKD, not only because of decreased renal clearance but also of alterations in their metabolism [270]. They have been shown to interfere with organic functions, such as causing an increase of leukocyte adhesion to vascular endothelium [271], activation of AhR [266] and decreased lipopolysaccharide-induced production of Tumor Necrosis Factor- $\alpha$ (TNF- $\alpha)$ [272]. Injections of kynurenic acid in rats with normal kidney function impaired their cognitive flexibility [273]. Furthermore they also modify metabolic functions by impairment of hepatic drug uptake [274], the activity of renal glucuronyltransferases [57] and energy metabolism by rat cerebral cortex [275].

In the general population, kyurenine levels were associated with all cause, cancer and cardiovascular mortality [276] and in patients with stable angina and myocardial infarction [277]. In patients with ESKD, the kynurenines were associated with oxidative stress, inflammation and prevalence of cardiovascular disease [278] and parameters of hypercoagulability [279].

\subsection{Phenols}

Of the phenols, phenylacetylglutamine, which conceivably is very little bound to protein, has been discussed above, in the section dealing with the small water-soluble compounds.

\subsubsection{Phenyl Sulfate}

To the best of our knowledge, the toxic effects of phenyl sulfate in the context of uremia have only rarely been studied. The solute affected tubular cell viability [229]. 


\subsubsection{Phenyl Acetic Acid}

Phenyl acetic acid as a protein bound uremic toxin does not seem to compete for its protein binding with other major protein bound uremic toxins like p-cresyl sulfate or indoxyl sulfate [280]. Phenyl acetic acid has been linked to inhibition of inducible nitric oxide synthase (iNOS) expression [281], osteoblast proliferation and differentiation [282], enhancement of the formation of oxygen free radicals in vascular smooth muscle cells [283] and increases of inflammatory response by polymorphonuclear leukocytes [284]. On the metabolic level, it inhibits renal cellular solute transport pumps [13] and conjugation by glucuronidation [57]. Finally, in a clinical study, phenyl acetic acid was related to cognitive dysfunction in dialysis patients [61].

\subsection{Quinolinic Acid}

Quinolinic acid is an oxidative product of tryptophan metabolism [285]. Also for this compound concentration may at least in part be increased in CKD by changes in the kynurenine metabolic pathway [270]. It contributes to the inhibition of erythropoiesis [285] and neurotoxicity [286]. The latter effect occurs via the intermediate of neuroinflammation [286].

\subsection{Summary}

Like with the small water-soluble molecules, these data show that also the protein bound solutes have the capacity to affect a host of biological systems that contribute to the uremic syndrome (Figure 2C, Supplementary Materials Table S2), with an average number of experimentally affected systems of $3.69 \pm 1.96$. The systems affected by the largest number of toxins are inflammation $(\mathrm{n}=11)$, as can be expected with protein bound solutes metabolic function $(n=11)$ and cardiovascular damage $(n=9)$. The group of toxins affecting the largest number of systems are the AGEs $(n=7)$ followed by the kynurenines $(n=5)$. As far as the individual compounds are concerned the list is headed by p-cresyl sulfate $(n=7)$, followed by indoxyl sulfate $(n=6)$, indole acetic acid and phenyl acetic acid $(\mathrm{n}=5)$ (Figure 2D).

The average evidence score is $2.31 \pm 0.95$ (maximum possible $=4$ ). For this aspect, the list is headed by the groups of the kynurenines ( $n=4$-the maximum score), followed by the AGEs $(\mathrm{n}=3)$. The highest scoring individual compounds were $\mathrm{p}$-cresyl sulfate $(\mathrm{n}=4)$ and indoxyl sulfate, indole acetic acid and phenyl acetic acid (score of 3) (Table 5).

Table 5. Summary of evidence data available on the protein bound compounds.

\begin{tabular}{|c|c|c|c|c|c|}
\hline Type of Evidence Points & Exp. Toxic 1-2 & $\begin{array}{l}\text { Exp. Neutral } \\
\text { or Benefit -1 }\end{array}$ & Clin. Toxic 1-2 & $\begin{array}{l}\text { Clin. Neutral } \\
\text { or Benefit -1 }\end{array}$ & Sum 4 (Max) \\
\hline AGEs * & 2 & 0 & 2 & -1 & 3 \\
\hline CMPF & 2 & 0 & 1 & -1 & 2 \\
\hline p-Cresyl sulfate & 2 & 0 & 2 & 0 & 4 \\
\hline p-Cresyl glucuronide & 1 & -1 & 1 & 0 & 1 \\
\hline o-OH hippurate & 2 & 0 & 0 & 0 & 2 \\
\hline Homocysteine & 2 & 0 & 1 & -1 & 2 \\
\hline Indoxyl sulfate & 2 & 0 & 2 & -1 & 3 \\
\hline Indole acetic acid & 2 & 0 & 1 & 0 & 3 \\
\hline Indoxyl glucuronide & 1 & 0 & 0 & 0 & 1 \\
\hline
\end{tabular}

Exp.: experimental; clin.: clinical (observational + Randomized Controlled Trials-RCTs); AGEs: Advanced Glycation End Products, AOPPs: Advanced Oxidation Protein Products; CMPF: Carboxy Methyl Propyl Furanpropionic Acid; p-OH hippurate: p-hydroxyhippurate; o-OH hippurate: o-hydroxyhippurate; * AGEs, AOPPs and kynurenines considered as one group; ${ }^{* *}$ skewed by confounders due to measurement errors (see text). 
Although most of the average evidence scores are not significantly different, the experimental data for the protein bound compounds seem to be more robust than the clinical ones. Indeed, toxins like homocysteine and indoxyl sulfate are not covered by unequivocal clinical data, whereas others like p-hydroxy hippuric acid, indole acetic acid, quinolinic acid and phenyl acetic acid have barely been studied clinically in spite of fairly robust experimental data.

\section{Middle Molecules}

The group of the middle molecules is mainly composed of small proteins or peptides that under normal conditions can cross the glomerular filtration barrier $(<58,000 \mathrm{Da})$. Their minimum molecular weight has arbitrarily been set at $500 \mathrm{Da}$ although most middle molecules have a molecular weight of more than 10,000 Da. The group contains both intact molecules and their degradation products. This degradation has been well described for some compounds (e.g., parathyroid hormone) but for many others not.

In contrast to the small water-soluble compounds and the protein bound solutes which to a large extent are intestinal metabolites of nutrition components, most of the middle molecules are generated endogenously. They are often part of homeostatic mechanisms to correct for other uremic changes (e.g., parathyroid hormone), or are expressed in response to other toxins (e.g., the cytokines), whereby their concentration not only depends on retention but also on endocrine and paracrine corrective mechanisms. A typical example is parathyroid hormone of which the concentration changes to a large extent are defined by alterations in bone homeostasis.

Because of their high molecular weight, dialytic removal is only possible with membranes with a large enough pore size (high-flux membranes) that can be used in a diffusive (hemodialysis) or convective mode (hemodiafiltration). To the best of our knowledge, few strategies exist to decrease concentration of specific middle molecules. Increasing their unspecific removal by applying large pore membranes often resulted in conflicting results with a number of clinical studies, even on hemodiafiltration as the most effective strategy, showing no hard outcome advantage at primary analysis [287-290]. Other studies showed a survival advantage but were prone to selection bias [291].

\subsection{Adrenomedullin}

The concentration of adrenomedullin is increased in dialysis patients but decreases when volume overload is corrected [292], which is suggestive of active secretion in overhydration. The molecule decreases intestinal epithelial permeability [293] and corrects cardiovascular malfunction [294]. It also has a mitogenic effect [295], which could be useful in repair function and for immune response but may also accelerate cell cycle in malignancy. Apart from the latter possibility, there are no manifest reasons to consider adrenomedullin as a real toxin. It rather seems a beneficial molecule with even a potential to correct for a number of elements of the uremic syndrome.

\subsection{Adiponectin}

Adiponectin is one of the adipokines of which the concentration is increased in CKD [1,5]. It is one of the compounds discussed in a review of this special issue on the cytokines [296]. However, the latter publication contains ample arguments stressing the uncertainties regarding the toxicity of this compound.

\subsection{Angiogenin}

Angiogenin is a member of the ribonuclease (RNAse) superfamily that next to stimulating angiogenesis, e.g., in cancer but also in wound repair [297], has been linked as well to inhibition of polymorphonuclear leukocyte degranulation [298], cytotoxicity and inhibition of protein synthesis [299]. 


\subsection{Atrial Natriuretic Peptide}

Atrial natriuretic peptide (ANP) as well as its sequence homologue, brain natriuretic peptide (BNP), are retained in uremia [1] and are independently linked to left ventricular mass and function and to overall and cardiovascular mortality in dialysis patients [300]. Yet, experimental studies on its physiologic impact not necessarily point to deleterious actions, as some data rather seem to suggest counter regulatory effects neutralizing a number of elements potentially contributing to the uremic syndrome. Enhanced ANP secretion has been suggested to play a role in the adaptive increase of sodium excretion per nephron in CKD [301] and decreases catecholamine release from nerve growth factor-treated rat pheochromocytoma cells by inducing a neuromodulatory effect [302]. When infused in rats with hypoxia-induced pulmonary hypertension, ANP attenuated pulmonary hypertension and reduced pulmonary vascular remodeling [303] and it also has been attributed a blood pressure lowering effect [304]. ANP also increases insulin levels in vivo [305], while in isolated rat pancreatic cells it inhibits glucagon secretion [306]. Both effects have the potential to restore at least in part the disturbed response to insulin in uremia. Maybe the only somewhat negative action we could retrieve is the inhibition of Follicle Stimulating Hormone (FSH) induced maturation of pig oocytes [307]. Of note, N-terminal pro-B-type natriuretic peptide (NT-proBNP) is an independent marker of renal anemia but is generally considered biologically inactive [308]. All data together suggest that atrial natriuretic peptide is a marker of negative outcomes, rather than a cause.

\section{5. $\beta_{2}$-Microglobulin}

The interest in $\beta_{2}$-microglobulin, the water-soluble extrinsic light chain of the Major Histocompatibility Class I (MHC I) molecules, was raised when it was demonstrated to be a major constituent of bone and joint amyloid deposits, which are at the origin of a devastating disorder of the locomotor system in renal patients, especially in those treated by dialysis [309]. Although the disease essentially has been linked to long-term renal replacement therapy, lesions were shown at the end of previous century to be present already from the second year of dialysis on, both in hemodialysis [310] and peritoneal dialysis patients [311]. Especially increased patient age at the onset of dialysis and the use of small pore complement activating cellulosic dialysis membranes as compared to large pore biocompatible AN69 membranes, seemed to affect the frequency of the disorder [312]. Interestingly, prevalence tended to decrease over the years following the detection of the problem [313]. This evolution was attributed to the introduction of large pore dialyzers and even more, to the improvement in quality of dialysis water [313].

A specific role in amyloid generation is attributed to the glycosylation of $\beta_{2}$-microglobulin by e.g., imidazolone [314] and $N^{\varepsilon}$-carboxymethyllysine [315]. Glycosylated $\beta_{2}$-microglobulin, in contrast to the naïve molecule, had a pro-inflammatory impact on human monocytes, with the potential to lead to bone and joint destruction [316]. More recent studies assessed the mechanisms of deposition of amyloid fibrils and point to the generation of specific component species prone to aggregation [317] and conformational changes attributable to the binding of calcium [318]. $\beta_{2}$-microglobulin fibrils then further affect function and/or viability of osteoblasts, osteoclasts and chondrocytes [319].

In various observational studies both in non-dialyzed [320] and dialyzed CKD patients [321-324] and even in populations not specifically selected because of CKD [325-327] $\beta_{2}$-microglobulin has been associated to hard outcomes or to surrogate outcomes like parameters of inflammation [323], vascular stiffness [323,324] or bone remodeling [326,327]. Although in some of these studies adjustments were made for GFR [320,325], it is difficult to support unequivocally the causative role of $\beta_{2}$-microglobulin from these data as the concentration of the molecule may sometimes have functioned as a surrogate for (residual) renal function.

From these observations, the question arises whether, apart from its role in renal amyloidosis, $\beta_{2}$-microglobulin should be considered as a toxin by itself or just simply as a marker of renal failure. A number of studies point in the direction of a biological (toxic) effect. In a proteomic study searching for a biomarker of peripheral artery disease, plasma $\beta_{2}$-microglobulin came out 
as a significant discriminator [328]. Kidney function was however lower in the affected patients, so that also in this study it remained unclear whether $\beta_{2}$-microglobulin was a patho-physiologic player, or whether it merely acted as a marker of kidney function, resulting in an only indirect link to vascular disease. An in vitro study showed a link between $\beta_{2}$-microglobulin and modifications in the molecular structure of the red blood cell plasma membrane, potentially affecting erythrocyte shape and their removal from the circulation [329]. In vivo and in vitro experimental studies showed an impact on osteoclast formation [330] and upregulation of TNF- $\alpha$ and Interleukin-6 (IL)-6 generation [330], epithelial-to-mesenchymal transition, be it in a cancer model [331] and a neurotoxic effect [332]. In a milestone study assessing functional neurologic changes during ageing, $\beta_{2}$-microglobulin was identified as a pro-ageing factor, impairing hippocampal cognitive and regenerative function [333]. However, in a study assessing the immunologic impact of $\beta_{2}$-microglobulin by using a commercially available $\beta_{2}$-microglobulin batch, the originally found strong pro-inflammatory effect disappeared after purification of the $\beta_{2}$-microglobulin solution by in vitro dialysis [334], suggesting a contaminant in the commercially available product. Hence, any finding of a biological effect of $\beta_{2}$-microglobulin and by extension of any uremic toxin, should be regarded with care.

$\beta_{2}$-microglobulin is considered as a prototypic middle molecule and is traditionally used as a marker of middle molecule removal, although both in pre-dialysis CKD [335] as in dialysis patients [336], $\beta_{2}$-microglobulin behavior did not necessarily conform with that of other middle molecules. Removal in a hemodialysis setting can only be obtained by using large pore membranes (so-called high-flux dialyzers) $[337,338]$. Removal can be further increased by adding convection (hemodiafiltration) [339-341] but also by extending the length of dialysis [342]. A strong decline in pre-dialysis $\beta_{2}$-microglobulin was obtained when several of these features were combined in extended daily hemodiafiltration [343].

Overall, the clinical suggestion of a link between $\beta_{2}$-microglobulin and negative outcomes is strong but may be confounded by (residual) renal function and selection bias. Also in view of the not too extensive biochemical proof of negative action of the compound, some may remain not completely convinced regarding the toxicity of $\beta_{2}$-microglobulin.

\section{6. $\beta$-Endorphin}

$\beta$-Endorphin concentrations are increased in uremia [344]. In analogy to cholestatic colitis, uremic pruritus has been linked to stimulation of central $\mu$-opioid receptors by accumulated endorphins, a hypothesis strengthened by the improvement of uremic itching in a randomized cross-over trial by the administration of the $\mu$-opioid receptor blocker naltrexone [345]. This study was however never confirmed [346] and both pre- and post-dialysis plasma $\beta$-endorphin levels could not be correlated to clinical itching scores in dialysis patients [347]. For the rest, there is only limited data on the biological impact of $\beta$-endorphin. In rat adrenal gland cells, an in vitro study from 1981 showed that $\beta$-endorphin induced aldosterone generation [348].

\section{7. $\beta$-Lipotropin}

$\beta$-Lipotropin is the precursor of $\beta$-endorphin and is also retained in uremia [344]. Consequently very likely all above conclusions about $\beta$-endorphin can also be extended to $\beta$-lipotropin, including its effect on the adrenal gland [348].

\subsection{Cholecystokinin}

Cholecystokinin has been associated to disturbed appetite of uremia and thus malnutrition $[349,350]$. In PD patients, the molecule measured in fasting state was correlated to a feeling of fullness and a lack of hunger perception [351]. In contrast, another study in PD patients found no difference in cholecystokinin levels between anorexic and non-anorexic patients and cholecystokinin levels were positively related to surrogate markers of nutritional status, such as serum albumin or triglycerides [352]. 


\subsection{Complement Factors $\mathrm{D}$ and $\mathrm{Ba}$}

Complement factor $\mathrm{D}$ as one of the elements of the complement cascade is retained in uremia [1,353] and has since long been considered to be one of the factors contributing to the pro-inflammatory status of uremia [1,2]. Retention is at least in part linked to a failure of renal catabolism [354]. In ESKD, extra-corporeal treatment over large pore membranes (hemofiltration) could remove a substantial fraction of complement factor D [355], which in part may be related to adsorption, as demonstrated for the polyacrylonitrile dialysis membrane [356]. Also, the immunosuppressive complement factor Ba is retained in uremia [357] and also this compound is removed by large pore extracorporeal strategies [355]. In view of this parallel retention and removal of a pro-inflammatory and an immunosuppressive factor, the final impact on the immunological balance of these complement factors remains unclear.

\subsection{Cystatin C}

Cystatin $C$ is best known as marker of kidney function and cystatin C based estimated GFR values have been shown to better correlate to hard outcomes than creatinine-based formulations [358-360]. Although originally considered as being unconfounded by other conditions, later studies showed several demographic confounding factors [361,362]. Cystatin $C$ is also produced by hematologic cell lines [255] and has been proposed as a biomarker of aggressive hematologic tumors [363]. To the best of our knowledge, there are almost no data pointing to a toxic effect of cystatin $C$ in a uremic setting. It is a major regulator of protease activity, prevents tumor metastasis and is neuroprotective [255]. In the context of Alzheimer, it protects against amyloid $\beta$ cytotoxicity [364] although it also seems to play an amyloidogenic role [255].

\subsection{Cytokines}

The cytokines are extensively reviewed in another article of this special issue [296]. That publication summarizes studies on the uremic toxicity of IL-1 $\beta$, IL-6 and TNF- $\alpha$ with data up to the level of RCTs and on IL-18 and IL- 8 with data up to the experimental and/or clinical observational level [296]. IL-10 is an anti-inflammatory cytokine and should not be considered as a uremic toxin [296]. However, because of this property it may be involved in the uremic propensity to infection. This review furthermore also contains information on the adipokines leptin, resistin and adiponectin that are discussed elsewhere in the present review.

\subsection{Endothelin}

Endothelins are strong vasoconstrictors [365]. Their concentration was shown to be increased in CKD [366]. Endothelin-1, via activation of one of its receptors, the endothelin-A (ETA) receptor, plays a deleterious role by increasing blood pressure and causing renal inflammation, oxidative stress, vascular shear stress, arterial stiffness, endothelial dysfunction and atherosclerosis [367,368]. Vascular endothelin production in CKD may be attenuated by antihypertensive treatment [369]. Renal production of endothelin-1 is however only reduced by angiotensin receptor blockade, a mechanism that may contribute to the renal protective effect of these drugs [369]. In experimental studies in CKD, specific blockade of the endothelin receptors reduced smooth muscle cell proliferation [370] and increased endothelial capillary density [371]. In a short term randomized cross-over study in CKD patients, Endothelin-A receptor blockade resulted in decreases of plasma urate, ADMA, proteinuria, hypertension and vascular stiffness [372,373]. Doubts on the long-term use of these agents was however raised when 3 to 6 months of treatment were not only associated with a reduction of proteinuria but also with a rise in mortality due to fluid retention [374] but maybe these problems could be overcome in future by using lower doses or more selective blockers [375]. Nevertheless, in spite of the contradictory results of hard outcome studies, enough proof-of-concept data have been provided to point to endothelin as a compound with major negative biological impact. 


\subsection{Fibroblast Growth Factor-23 (FGF-23)}

The toxicity of FGF-23, a relative newcomer in the field of uremic toxicity research, is reviewed in depth in the current special issue [376]. Interestingly, this compound that in observational studies appeared to correlate extensively with negative outcomes, has now been shown to exert direct toxicity as well [376]. Hence, FGF-23 is not a mere marker of CKD and its hard outcomes but it can now also be considered as one of the potential culprits of the uremic syndrome.

\subsection{Ghrelin}

Ghrelin levels have definitely been shown to be increased in CKD [377-380]. Ghrelin is known as an orexigen playing a role in meal initiation [381] and as such seems to oppose the trend for malnutrition of most CKD patients. However, the molecule has also been linked to several other negative biological activities, such as restricted insulin release [382] and blunted insulin sensitivity [383], increases in triglyceride content in the liver [384], mitochondrial oxidative enzyme activities [384], anxiogenic response to stress [385], increase in serum corticosterone levels [385], release of growth hormone [386] and increases in sodium reabsorption [387,388]. On the other hand, ghrelin also has been linked to a rise in cardiac index and stroke volume index [389].

Clinically, low ghrelin levels have been associated with inflammation and cardiovascular risk in hemodialysis patients [390]. On the other hand, ghrelin correlated negatively with body mass index [377]. In PD patients weight gain over time was associated to a decrease of ghrelin levels [377]. In another study, ghrelin levels were inversely correlated to nutritional makers suggesting increases in ghrelin at low dietary intake [380]. The acute response to oral feeding in CKD was however markedly blunted versus controls [379]. A possible explanation for the seeming paradox between uremic malnutrition and elevated ghrelin can be found in the finding that ghrelin is present in the body in two forms, the orexigen acylated ghrelin and desacylated ghrelin which induces a negative energy balance by decreasing food intake and gastric emptying [391]. The balance between these two forms has repeatedly been shown to be disrupted in CKD, with more prominent retention of desacyl ghrelin [378,392,393]. Plasma desacyl ghrelin was significantly higher in anorexic hemodialysis patients [392].

\subsection{Glomerulopressin}

The only functional effect of glomerulopressin that could be found was an increase of glomerular filtration rate and potassium excretion [394].

\subsection{Immunoglobulin Light Chains}

Although typical for multiple myeloma and other hematologic malignancies [395], the concentration of the immunoglobulin light chains is also above normal in patients with CKD not suffering from those conditions [396,397]. These molecules have been depicted as markers to inflammation but possibly also as pathogenetic factors [398,399]. Experimental studies applying immunoglobulin light chains at concentrations as observed in CKD demonstrated that they decreased polymorphonuclear glucose uptake and chemotaxis [400] but also leukocyte apoptosis, a factor possibly contributing to chronic inflammation [401]. After their filtration by the glomeruli, immunoglobulin light chains are incorporated via the cubilin receptors into the renal proximal tubular cells [402] where they are catabolized [403] and where they tend to accumulate if the system is overloaded [404] to cause morphologic changes [405] and kidney injury [406], be it essentially at the extremely high concentrations of hematologic malignancies [407]. Their toxicity may be further enhanced by glycosylation [408]. In observational studies in CKD, their concentration has been associated to inflammation and vascular calcification in one study [409] and mortality in another one [396], although in the first study adjustment for well-known cardio-vascular risk factors abolished the link to mortality [409]. In ESKD, immunoglobulin light chains can only be removed by dialysis 
via large pore high-flux membranes, although treatment does not reduce levels to normal [397,410]. Substantially better removal could be obtained by using extremely open high cut-off (HCO) dialyzer membranes but at the expense of considerable albumin losses [411]. The novel medium cut-off (MCO) membranes are an intermediate between classical high-flux and HCO, allowing better albumin conservation. For removal of immunoglobulin light chains, they are more efficient in a hemodialysis mode than classical high-flux membranes in hemodiafiltration [412].

\subsection{Modified Lipids and Lipoproteins}

Oxidation does not only modify proteins but also lipids and next to oxidation, there are also other post-translational lipid modifications at play in CKD, such as glycation and carbamylation. As summarized by a review in this special issue, they play a role in inflammation, apoptosis, endothelial dysfunction and accelerated atherosclerosis [413].

\subsection{Leptin}

Leptin is a satiety hormone that is part of the review on the cytokines in this special issue [296]. In spite of ample experimental arguments in favor of its biological activity [414], clinical data are contradictory and not convincing, leading to the conclusion in the above mentioned publication that its status as a uremic toxin is debatable [296].

\subsection{Macrophage Colony Stimulating Factor}

Macrophage Colony Stimulating Factor (or Colony Stimulating Factor-1-CSF-1) was originally described as a promotor of proliferation and differentiation of hematologic progenitor cells [415] but soon appeared to stimulate also the activity of mature leukocytes, by stimulating neutrophil metabolism and cytotoxicity [416,417] as well as monocyte cytokine production [418]. Hence, Macrophage CSF might be a key factor in inflammatory conditions [419], including CKD [420]. However, also beneficial effects have been attributed to it, such as regression of atherosclerotic lesions [421], recovery from leukocytopenia [422] and kidney repair from ischemia [423]. After addition of this component as an adjuvant to a hepatitis B vaccine, an improved response to vaccination was observed in hemodialysis patients [424].

\subsection{Methionine-Enkephalin}

Methionine-enkephalin is another opioid of which the concentration is increased in CKD [425,426]. Methionin-enkephalin plays a role in suppressing the feeling of pain $[427,428]$, enhances the secretion of several hormones [429], suppresses renal nerve activity [430] and inhibits jejunal fluid secretion [431].

\subsection{Neuropeptide $Y$}

Neuropeptide $Y$, a known major orexigen [349,350,432], is retained in CKD [433,434]. In peritoneal dialysis patients, low neuropeptide $Y$ levels are associated with anorexia [352]. In the nervous system, neuropeptide $\mathrm{Y}$ inhibits the release of the neurotransmitter acetylcholine in nodose neurons [435]. Neuropeptide $\mathrm{Y}$ also acts as a renal vasoconstrictor by suppression of adenylate cyclase activity, a regulator of a wide array of cellular processes in vascular smooth muscle cells [436]. Likewise, neuropeptide $\mathrm{Y}$ also inhibits cardiac adenylate cyclase [437] and the combination of high leptin, peptide $Y Y$ and neuropeptide $Y$ together with low ghrelin has in the hemodialysis population been linked to hypertension, inadequate vasodilation and cardiac hypertrophy and hence could predispose to cardiovascular events [438]. In an observational study, neuropeptide $\mathrm{Y}$ predicted cardiovascular complications in ESKD [439]. 


\subsection{Orexin $A$}

Orexin A is another orexigen [440] of which the messenger RNA expression is suppressed in CKD [441]. It was difficult to find data on its concentration in CKD and also the data on the biological impact are scarce, especially in uremia. Studies with normal kidney function and usually after central injection show a stimulation of testosterone production [442] and a rise in blood pressure and tachycardia in stressful conditions [443].

\subsection{Parathyroid Hormone (PTH)}

Disturbances in concentration of PTH, phosphate and FGF-23 are strongly linked to each other whereby changes in one factor impact generation of the other, often following an adaptive response mechanism [444,445]. The biological impact of PTH has extensively been studied and summarized and covers multiple aspects such as peripheral neuropathy, carbohydrate metabolism, hypertension, mitochondrial respiration and cardiac hypertrophy [445]. Yet, due to inherent PTH-resistance in CKD, PTH levels need to be more elevated than with normal kidney function before generating an effect [445]. In observational studies, both low and high PTH levels have been linked to increased mortality, with a more pronounced relationship for the low levels [445,446], which are linked to adynamic bone disease. Hence, the validity of parathyroid hormone as a marker of bone turnover and generator of cardiovascular disease has been questioned [447]. In two RCTs, parathyroid hormone lowering treatment with the calcimimetic Cinacalcet did not impact the primary endpoints of the studies $[448,449]$ but influenced a number of surrogate endpoints such as vascular and cardiac valve calcification [448]. In a secondary analysis of one of these two trials, the EValuation Of Cinacalcet Hydrochloride $(\mathrm{HCl})$ Therapy to Lower CardioVascular Events (EVOLVE) study, Cinacalcet appeared to lower FGF-23 and these reductions were linked to a lower number of cardiovascular events and death [450]. As the rise in FGF-23 precedes the rise in parathyroid hormone and serum phosphate, the question may be raised whether the rise in FGF-23 is not the primary pathophysiologic event in the development of secondary hyperparathyroidism [451]. However, FGF-23 neutralization with antibody in mice with kidney failure improved hyperparathyroidism but increased mortality [452]. All data taken together, the pathophysiologic role of parathyroid hormone in CKD cannot be supported unequivocally.

\subsection{Pentraxin-3}

Pentraxin-3 is an acute phase protein produced by a variety of cells in response to inflammatory signals [453]. The pentraxins are considered to be useful biomarkers of systemic inflammation [454]. Pentraxin-3 levels have repeatedly been shown to be increased in CKD [455-457]. Direct proof of a biological effect is scarce. One study linked Pentraxin-3 to epithelial-to mesenchymal transition and renal fibrosis [458]. In addition, pentraxin-3 was found in foam cells of advanced atherosclerotic lesions and in leukocytes infiltrating atherosclerotic plaque [459]. However, most studies linking Pentraxin-3 to negative outcomes are clinical observational and associate the molecule to endothelial dysfunction [457,460], cardiovascular disease [455-457,460,461], protein energy wasting [455,457] and in a study focusing on the elderly, also incident CKD [462]. In unselected hypertensive diabetics, antihypertensive treatment improved flow-mediated vessel dilation and normalized proteinuria but normalized Pentraxin-3 as well $[463,464]$. Moreover, in hypertensive type 2 diabetics, the improvement in flow-mediated vasodilation related to antihypertensive treatment was independently associated with Pentraxin-3 concentration [464]. Yet, in animal experiments in mice, Pentraxin-3 infusion attenuated renal damage in diabetic nephropathy [465], whereas knock-out mice lacking pentraxin-3 showed more vascular inflammation and macrophage accumulation within atherosclerotic plaque [466]. In obese CKD patients pentraxin-3 levels were low in spite of enhancement of other inflammatory markers [467]. In a functional ex vivo study, subcutaneous fat tissue pentraxin-3 mRNA was inversely correlated to ADMA concentration and basal resistance artery tone [468]. The latter studies suggest that in some 
circumstances, pentraxin-3 may play a counter regulatory role in endothelial damage. On the other hand, in the observational arm of the same study, adipose pentraxin-3 mRNA was increased in CKD patients with cardiovascular disease but the association disappeared after adjustment [468]. Overall, there seem to be as much arguments in favor as in disfavor of the biological toxicity of pentraxin-3.

\subsection{Peptide $Y Y$}

Peptide YY is an anorexigen $[469,470]$ and inhibitor of gastric motility [471]. Elevated levels have been recorded in CKD patients on peritoneal dialysis [472] and on hemodialysis [438], although its postprandial secretion was markedly decreased as compared to healthy controls [472]. Studies on biological effects are scanty. Infusion of peptide YY was shown to decrease glomerular filtration rate, plasma renin activity and aldosterone levels, whereas urinary sodium excretion was raised [473]. It has been hypothesized that the combination of high leptin, peptide $Y Y$ and neuropeptide $Y$ together with decreased ghrelin would predispose to hypertension, impaired vasodilation and cardiac hypertrophy [438], although the decrease of renin and aldosterone mentioned above [473] may cast some doubts on the contribution of peptide $Y Y$ into this. On the other hand, on the pancreatic level, peptide YY seems to be essential for beta cell survival, insulin secretion and glycemic control [474,475].

\subsection{Prolactin}

Hyperprolactinemia is common in CKD and has been observed since many years [476-479]. As a hormone involved in reproductive behavior [480] it could play a role in sexual dysfunction of uremia [481] but treatment with bromocryptin could suppress prolactin but did not correct sexual dysfunction in hemodialysis patients of both genders [479]. There are only limited data on the biological action of prolactin, which has been linked to platelet activation [482]. On the other hand, under physiologic non-uremic conditions, prolactin has a homeostatic role, e.g., in maintenance of immune function, osmoregulation, suppression of angiogenesis and by extension possibly also in tumor genesis [480]. One observational clinical study linked prolactin to markers of endothelial dysfunction and cardiovascular morbidity and mortality [476]. A similar relation with major cardiovascular events has also been observed in males without CKD but with erectile dysfunction [483].

\subsection{Resistin}

Resistin is included in the review on cytokines which is part of this special issue [296] but is not considered a uremic toxin. In spite of a few suggestive experimental studies, no link with hard outcomes in CKD could as yet be demonstrated [296].

\subsection{Retinol Binding Protein}

Retinol binding proteins are not only transporters of retinoids but also function as regulators of retinoid metabolism and disposition [484]. They have extensively been studied in CKD and were repeatedly shown to be elevated [485-489], although levels do not correlate as well with GFR than Cystatin $C$ or $\beta_{2}$-microglobulin $[335,490]$. Contradictory biological functions have been attributed to this molecule. On one hand, retinol binding protein has been shown to induce apoptosis and inflammatory reaction in human endothelial cells [491,492]. On the other hand, retinol binding protein isolated from acute kidney failure patients inhibited polymorphonuclear cell function and apoptosis [401]. Quite a number of observational studies in specific populations not necessarily suffering from CKD link retinol binding protein to cardiovascular disease [493], carotid intima thickness [494], the metabolic syndrome [495-497] and obesity [496]. Only a few observational studies assessed links of retinol binding protein with outcomes in specific populations suffering from CKD. In one study serum levels were associated to components of the metabolic syndrome [488]. In a population of type 2 diabetics with and without CKD, serum retinol binding protein was however not related to carotid intima thickness [498]. On the other hand urinary retinol binding protein was 
inversely related to kidney function and cardiovascular risk factors [499] and was also increased in proportion with the degree of renal radiation damage in mice [500].

\subsection{Visfatin}

Visfatin is included in the review on cytokines which is part of this special issue [296]. Also, this molecule was discarded as a potential uremic toxin, because of contradictory clinical data [296].

\subsection{Summary}

Like with the two other large groups of uremic retention solutes, these data show that also the middle molecules have the capacity to affect a number of biological systems that contribute to the uremic syndrome. The average number of experimentally affected systems $(2.34 \pm 1.57)$ is significantly lower $(\mathrm{P}=0.012)$ than for the protein bound compounds but comparable to the small water-soluble compounds. The systems affected by the largest number of toxins are cardiovascular system $(\mathrm{n}=21)$, inflammation $(\mathrm{n}=16)$ and fibrosis $(\mathrm{n}=12)$ (Figure 2E, Supplementary Materials Table S3). Of note, protein energy wasting, without directly involved molecules within the two other groups, appeared to be affected by 4 of the middle molecules, pointing to the many peptidic structures that function as an anorexigen. There are relatively few middle molecules that have been demonstrated to affect more than 4 biological systems (Figure 2F, Supplementary Materials Table S3), suggesting a relative scarcity of experimental studies in this group of molecules. The molecules with the largest impact are: $\beta_{2}$-microglobulin (6 affected systems) and ghrelin, leptin and parathyroid hormone (all $\left.n=5\right)$.

The average evidence score (Table 6) is $2.06 \pm 1.19$ (maximum possible $=4$ ). For this characteristic, the list is headed by $\beta_{2}$-microglobulin, interleukin-6, TNF- $\alpha$ and FGF-23 $($ all $n=4)$.

Table 6. Summary of evidence data available on the middle molecules.

\begin{tabular}{|c|c|c|c|c|c|}
\hline Type of Evidence Points & Exp. Toxic 1-2 & $\begin{array}{l}\text { Exp. Neutral } \\
\text { or Benefit -1 }\end{array}$ & Clin. Toxic 1-2 & $\begin{array}{l}\text { Clin. Neutral } \\
\text { or Benefit -1 }\end{array}$ & Sum 4 (max) \\
\hline Adrenomedullin & 1 & -1 & 0 & 0 & 0 \\
\hline Adiponectin & 0 & 0 & 2 & -1 & 1 \\
\hline Angiogenin & 2 & 0 & 0 & 0 & 2 \\
\hline ANP & 1 & -1 & 1 & 0 & 1 \\
\hline$\beta_{2}$-microglobulin & 2 & 0 & 2 & 0 & 4 \\
\hline$\beta$-endorphin & 1 & -1 & 1 & 0 & 1 \\
\hline$\beta$-lipotropin & 1 & -1 & 1 & 0 & 1 \\
\hline Cholecystokinin & 0 & 0 & 2 & -1 & 1 \\
\hline Complement factor D & 2 & 0 & 0 & 0 & 2 \\
\hline Complement factor $\mathrm{Ba}$ & 2 & 0 & 0 & 0 & 2 \\
\hline Cystatin C & 1 & -1 & 2 & 0 & 2 \\
\hline Interleukin-1 $\beta$ & 2 & 0 & 0 & 0 & 2 \\
\hline Interleukin-18 & 2 & 0 & 1 & 0 & 3 \\
\hline Interleukin-6 & 2 & 0 & 2 & 0 & 4 \\
\hline TNF- $\alpha$ & 2 & 0 & 2 & 0 & 4 \\
\hline Interleukin-8 & 2 & 0 & 1 & 0 & 3 \\
\hline Interleukin-10 & 2 & 0 & 1 & $-1 *$ & 2 \\
\hline Endothelin & 2 & 0 & 2 & -1 & 3 \\
\hline FGF-23 & 2 & 0 & 2 & 0 & 4 \\
\hline Ghrelin & 2 & 0 & 2 & -1 & 3 \\
\hline Glomerulopressin & 0 & 0 & 0 & 0 & 0 \\
\hline $\operatorname{IgLC} * *$ & 2 & 0 & 2 & -1 & 3 \\
\hline Lipids \& lipoproteins $* * * * * *$ & 2 & 0 & 1 & 0 & 3 \\
\hline Leptin & 2 & 0 & 0 & 0 & 2 \\
\hline MCSF & 2 & -1 & 1 & 0 & 2 \\
\hline Methionine-enkephalin & 2 & -1 & 0 & 0 & 1 \\
\hline Neuropeptide Y & 2 & -1 & 2 & 0 & 3 \\
\hline Orexin A & 1 & -1 & 0 & 0 & 0 \\
\hline Parathyroid hormone & 2 & 0 & 2 & -1 & 3 \\
\hline Pentraxin-3 & 2 & -1 & 2 & -1 & 2 \\
\hline Peptide YY & 1 & -1 & 0 & 0 & 0 \\
\hline Prolactin & 1 & -1 & 2 & 0 & 2 \\
\hline Resistin & 2 & 0 & 0 & 0 & 2 \\
\hline Retinol Binding Protein & 2 & 0 & 2 & -1 & 3 \\
\hline Visfatin & 0 & 0 & 2 & -1 & 1 \\
\hline
\end{tabular}

Exp.: experimental; clin.: clinical (observational + Randomized Controlled Trials-RCTs); ANP: atrial natriuretic peptide, TNF- $\alpha$ : Tumor Necrosis Factor- $\alpha$, IgLC: Immunoglobulin Light Chains; MCSF: Macrophage Colony Stimulating Factor; * paradoxically correlated to consequences of inflammation whereas the biological action is anti-inflammatory; ${ }^{* *}$ immunoglobulin light chains and lipids and lipoproteins considered as one group; *** modified-posttranslational. 


\section{Discussion}

This review summarizes the current knowledge about the biological impact (toxicity) of uremic retention compounds. From this analysis, it appears that there is a plethora of compounds that exert some degree of toxicity. In total 8 groups of compounds and 63 individual compounds (20 small water-soluble, 16 protein-bound and 35 middle molecules) are reviewed of which 66 (93\%) are modifying the activity of at least one functional system. Hence, the uremic syndrome is, with regards to the patho-physiologic impact of the retained solutes, a multifactorial condition. It seems highly improbable that one day a "golden bullet" would be identified, of which the removal would solve the entire problem. We are rather confronted with groups of compounds depending on various characteristics (protein bound vs. not; high molecular weight vs. low; hydrophilic vs. hydrophobic; intestinally generated vs. not; secreted by the renal tubules vs. not) that should be handled together if it comes to decrease their concentration.

When we consider the number of functional systems disturbed per molecule, the highest score of 7 on 11 systems considered is reached by one group of small water-soluble compounds (the polyamines), one group of protein bound solutes (the AGEs) and one individual protein bound compound ( $p$-cresyl sulfate) and no middle molecule. The second highest score of 6 is reached by one small water-soluble compound (uric acid), one protein bound compound (indoxyl sulfate) and one middle molecule ( $\beta_{2}$-microglobulin). Obviously, it is easier to reach a high score for solutes that are considered as a group (e.g., the AGEs and the polyamines) than for the other solutes that are considered individually. In addition, the score per solute depends on the frequency a solute or group of solutes was studied and per physico-chemical type, on the number of solutes or groups of solutes included in that category. Taking these into account, it could be concluded that the number of high scores is limited for the middle molecules in spite of the fact that it actually happens to be the largest group of individual entries $(n=35)$. This impression is confirmed by the, be it not always significant lower average score for the number of affected systems $(2.34 \pm 1.57$ vs. $2.65 \pm 1.95$ and $3.69 \pm 1.96$ for the small water-soluble compounds and the protein bound compounds, respectively-Table 7). This points to the relatively low number of experimental studies on the middle molecules in general, either due to a low intrinsic number of investigations, maybe since their toxicity is automatically taken for granted, or to a reporting bias with negative results remaining unpublished. On the other hand, the superiority of protein bound solutes with regards to experimental data seems largely lost when the overall evidence score is taken into account (Table 7).

Table 7. Mean scores for each major toxin group for the number of affected systems in experimental studies and for the average evidence score (experimental + clinical).

\begin{tabular}{ccc}
\hline & $\begin{array}{c}\text { Number of Affected Systems in } \\
\text { Experimental Studies }\end{array}$ & Average Evidence Score \\
\hline Small water-soluble compounds & $2.65 \pm 1.85$ & $1.75 \pm 1.29$ \\
Protein bound solutes & $3.69 \pm 1.96^{*}$ & $2.31 \pm 0.95$ \\
Middle molecules & $2.34 \pm 1.57$ & $2.06 \pm 1.19$ \\
\hline
\end{tabular}

Original data on which the calculations are based are shown in Figure 2, Tables 4-6 and Supplemental Tables S1-S3.

${ }^{*} p=0.012$ vs. middle molecules.

Thus, our data suggests that the number of experiments assessing the biochemical impact of individual retention compounds might be increased, especially for the middle molecules and to a certain extent also for the small water-soluble compounds. Indeed, whereas the protein bound solutes have largely been neglected until the mid-nineties of previous century, their analysis has received a substantial boost since then. In addition, however, we also stress the importance, for researchers, to report negative results and for journals, to publish them.

In this context, it should also be noted that, whereas most uremic toxin research has up to now focused on single toxins, in real life they are present together in the body. The problem of mutual 
interaction of toxins can only be solved by studying solute panels, although this approach may be hampered by problems of solubility if several molecules are combined together and correct uremic concentrations have to be obtained [501].

For a total number of 71 solutes or solute groups, a negative effect per functional system was reported for 41 molecules or groups on the cardiovascular system (58\% of considered solutes), followed by 37, 26, 23 and 15 molecules (52\%, 37\%, 32\% and 21\%) for inflammation, metabolic function, fibrosis and neurotoxicity respectively. All these findings point to a multifactorial disintegration of some of the key elements which define morbidity and mortality of our patients on dialysis and already a long time before dialysis is initiated (cardiovascular damage, inflammation and fibrosis as a cause of heart failure and progression of CKD). However, because of this patho-physiologic importance, these systems may also have been assessed more frequently, hence leading to an underrepresentation of the other systems, although they are important as well for the quality of life of CKD patients. In general, it seems that we could retrieve for this review only few studies that assessed quality of life or factors defining quality of life in uremia (e.g., pruritus, insomnia). This lack of patient-centered analyses is another shortcoming that could be corrected in future.

A direct effect on protein energy wasting (PEW) was conveyed only 4 times but some of the other frequently reported systems (inflammation, cardiovascular disease, neurotoxicity, infection) as such are an indirect cause of protein energy wasting.

For the overall evidence score (experimental + clinical, with correction for results indicating no effect or a beneficial effect) the maximum score of 4 was reached by 3 small water-soluble compounds or groups of compounds (ADMA, SDMA and the carbamylated products) and 4 middle molecules ( $\beta_{2}$-microglobulin, TNF- $\alpha$, interleukin-6 and FGF-23) but only in two protein bound solutes or solute groups (p-cresyl sulfate and the kynurenines) (Table 8). In part, the latter finding could be linked to the number of protein bound solutes considered which is lower than that of the two other groups. Yet, this figure is markedly low as compared to the experimental data that were retrieved. Hence, our data point to a relative shortage of clinical hard outcome studies on some of the protein bound uremic toxins (e.g., indole acetic acid, phenyl acetic acid, p-OH hippuric acid). On the other hand, the score was also often downgraded because of too many observational studies showing no association with hard outcomes. Such neutral results might be real but may also be the consequence of insufficiently powered studies or confounding by unrecognized or unknown factors. This is the reason why in Table 8 summarizing the highest scoring solutes we also included solutes with score 3 .

Table 8. Uremic toxins with the highest toxicity score.

\begin{tabular}{|c|c|c|c|}
\hline Evidence Score: 4 & Exp. Score & Evidence Score: 3 & Exp. Score \\
\hline p-Cresyl sulfate & 7 & AGEs & 7 \\
\hline$\beta_{2}$-Microglobulin & 6 & Indoxyl sulfate & 6 \\
\hline ADMA & 5 & Uric acid & 6 \\
\hline Kynurenines & 5 & Ghrelin & 5 \\
\hline Carbamylated compounds & 3 & Indole acetic acid & 5 \\
\hline FGF-23 & 3 & Parathyroid hormone & 5 \\
\hline Interleukin-6 & 3 & Phenyl acetic acid & 5 \\
\hline TNF- $\alpha$ & 3 & TMAO & 5 \\
\hline \multirow[t]{7}{*}{ SDMA } & 2 & Retinol binding protein & 4 \\
\hline & & Endothelin & 3 \\
\hline & & IgLC & 3 \\
\hline & & Interleukin-1 $\beta$ & 3 \\
\hline & & Interleukin-8 & 3 \\
\hline & & Neuropeptide $Y$ & 3 \\
\hline & & Lipids \& lipoproteins & 2 \\
\hline
\end{tabular}

Exp.: experimental; ADMA: Asymmetric Dimethylarginine; FGF23: Fibroblast Growth Factor-23; TNF- $\alpha$ : Tumor Necrosis Factor; SDMA: Symmetric Dimethylarginine; AGEs: Advanced Glycation End Products; TMAO: Trimethylamine-N-Oxide; IgLC: Immunoglobulin Light Chains. 
When listing the highest ranking molecules with regards to their toxicity (overall evidence score $\geq 3$, experimental score $\geq 5$ ) the following molecules or groups of molecules could be retained (Table 8): for the small water-soluble compounds, ADMA, uric acid and TMAO; for the protein bound compounds, p-cresyl sulfate, kynurenines, AGEs, indoxyl sulfate, indole acetic acid, phenyl acetic acid; for the middle molecules, $\beta_{2}$-microglobulin, ghrelin, parathyroid hormone.

RCTs are currently accepted to offer the highest level of evidence for a given impact. Although there are some RCTs on interventions to decrease the concentration of specific toxins, they are few, largely due to the low number of available interventional therapies that specifically can change concentration of a given uremic toxin. In view of the multifactorial pathophysiology that can be understood from this and other reviews [3], one may wonder whether it makes much sense to further consider specific interventional trials to decrease one single solute in the context of uremia, unless to offer proof of concept of toxic effects. In addition, such therapies are not always innocent. Allopurinol e.g., may reduce uric acid but any positive effect that is generated might be partially offset by its complications, such as Stevens-Johnson syndrome or leukocytopenia. Hence, it might be more useful to try to influence the concentration or metabolic impact of groups of molecules with similar characteristics. Thus, we still remain in need of randomized controlled trials in the area of CKD, or alternatively, of observational trials with optimized corrective strategies for residual confounding but they should preferentially be focused on larger groups of molecules. Observational studies might have an advantage on controlled studies by better mimicking real life conditions, in an area where many randomized controlled trials turned out negative at primary analysis for hard outcomes [161,162,287-289,338,449,502,503].

This is the first analysis of the biological capacity of the majority of currently known uremic compounds since almost two decades. Not only data from the nephrologic literature but also a large array of non-nephrologic journals were taken into account. In addition, when neutral or beneficial results had been reported, these were also taken into consideration in our scoring systems.

This analysis, although comprehensive, also has a number of drawbacks. First, we may have failed to include some compounds. However, as we started from existing uremic databases $[1,5]$ the risk that this would have been the case is relatively low and if it happened, it is unlikely that one of the currently known major contributors to the uremic syndrome will have been missed. Second, we may have overlooked a number of studies showing a biological impact, since this analysis is not based on a systematic review. Systematic reviews are strenuous endeavors, simultaneously involving several researchers for substantial time periods, so that for practical reasons they are to be restricted to a limited number of toxins [20] and should be considered as an inappropriate tool for a comprehensive review such as the present one. In addition, if some references are missing, it is more likely to have occurred for those solutes that have been studied extensively, than for those with a limited number of data. For that reason, it is improbable that substantial shifts would occur in the scores of the individual solutes and even more in the global assessment per large group of solutes if the literature base for their analysis would have even been larger than it already is with close to 500 publications included in the reference list. However, in future, it might be useful to consider more in depth systematic analysis of solutes scoring high in this assessment, to see whether their present score was justified. Likewise, we did not check whether in all cited studies the correct concentrations as observed in uremia were applied, which would be another element to be assessed by a systematic review. However, we are convinced that this review and especially the classification offered in Table 8, will be helpful in future to select the most important toxins if such systematic reviews were planned. Finally, the perception emanating from this review may be confounded by publication bias. On one hand, negative results may have retained insufficient attention, on the other hand the impression of the toxicity of some other solutes may seem overwhelming, because they were more frequently the subject of studies. 


\section{Conclusions}

We thus believe that this review will offer a useful reference work giving a better insight in the complex picture of uremia to those interested and at the same time hope it is a stimulus to fill in the gaps in knowledge that still exist and that it could serve as a good reference work for future uremic toxicity analyses and for selecting mechanisms for future drug development in the treatment of the uremic syndrome. Our ranking system may also be of help for defining the target molecules in removal studies and for developing novel methods improving this removal or removing molecules that up till now received insufficient attention.

The scores are also likely to stimulate clinical and/or translational research on specific uremic toxins or groups of toxins by clarifying for which compounds and for which physiologic systems data are abundant and for which not.

We demonstrated a kaleidoscopic picture of the many compounds involved in defining the pathophysiologic process that ultimately results in the uremic syndrome. We summarize the biological/biochemical and clinical impact of 71 uremic retention solutes that have been assessed over the past half of a century. A complex picture emerges whereby almost all considered solutes affect one or more functions that contribute to the uremic syndrome and its complications, leading to the increased morbidity and mortality of CKD. Of the affected mechanisms, especially the susceptibility to cardiovascular damage, inflammation and fibrosis appeared to be targeted but these systems have presumably also been studied most extensively. Some discrepancies between experimental and clinical data became apparent, leading sometimes to a downgrade of positive looking experimental scores. In addition, it became clear that the quantity of experimental data for the middle molecules and to a certain extent also for the small water-soluble compounds could be larger, whereas clinical data are missing for several of the protein bound solutes in spite of quite robust experimental data being available. In view of the apparently multifactorial nature of uremia, it seems illusory to think that decreasing the concentration of one single solute will improve outcomes and probably attention should concentrate on decreasing the concentration of groups of solutes. More attention could be paid to quality of life aspects.

Supplementary Materials: The following are available online at www.mdpi.com/2072-6651/10/1/33/s1, Table S1: Experimental effects observed for the small water-soluble compounds, Table S2: Experimental effects observed for the protein bound compounds, Table S3: Experimental effects observed for the middle molecules.

Acknowledgments: Anneleen Pletinck is a postdoctoral fellow of the Research Foundation-Flanders (FWO).

Conflicts of Interest: The authors declare no conflict of interest.

\section{References}

1. Vanholder, R.; De Smet, R.; Glorieux, G.; Argiles, A.; Baurmeister, U.; Brunet, P.; Clark, W.; Cohen, G.; De Deyn, P.P.; Deppisch, R.; et al. Review on uremic toxins: Classification, concentration, and interindividual variability. Kidney Int. 2003, 63, 1934-1943. [CrossRef] [PubMed]

2. Wikoff, W.R.; Nagle, M.A.; Kouznetsova, V.L.; Tsigelny, I.F.; Nigam, S.K. Untargeted metabolomics identifies enterobiome metabolites and putative uremic toxins as substrates of organic anion transporter 1 (oat1). J. Proteome Res. 2011, 10, 2842-2851. [CrossRef] [PubMed]

3. Vanholder, R.; Fouque, D.; Glorieux, G.; Heine, G.H.; Kanbay, M.; Mallamaci, F.; Massy, Z.A.; Ortiz, A.; Rossignol, P.; Wiecek, A.; et al. Clinical management of the uraemic syndrome in chronic kidney disease. Lancet Diabetes Endocrinol. 2016, 4, 360-373. [CrossRef]

4. Vanholder, R.; De Smet, R. Pathophysiologic effects of uremic retention solutes. J. Am. Soc. Nephrol. JASN 1999, 10, 1815-1823. [PubMed]

5. Duranton, F.; Cohen, G.; De Smet, R.; Rodriguez, M.; Jankowski, J.; Vanholder, R.; Argiles, A.; European Uremic Toxin Work Group. Normal and pathologic concentrations of uremic toxins. J. Am. Soc. Nephrol. JASN 2012, 23, 1258-1270. [CrossRef] [PubMed] 
6. Boelaert, J.; Lynen, F.; Glorieux, G.; Schepers, E.; Neirynck, N.; Vanholder, R. Metabolic profiling of human plasma and urine in chronic kidney disease by hydrophilic interaction liquid chromatography coupled with time-of-flight mass spectrometry: A pilot study. Anal. Bioanal. Chem. 2017, 409, 2201-2211. [CrossRef] [PubMed]

7. Vanholder, R.; Boelaert, J.; Glorieux, G.; Eloot, S. New methods and technologies for measuring uremic toxins and quantifying dialysis adequacy. Semin. Dial. 2015, 28, 114-124. [CrossRef] [PubMed]

8. Aronov, P.A.; Luo, F.J.; Plummer, N.S.; Quan, Z.; Holmes, S.; Hostetter, T.H.; Meyer, T.W. Colonic contribution to uremic solutes. J. Am. Soc. Nephrol. JASN 2011, 22, 1769-1776. [CrossRef] [PubMed]

9. Rhee, E.P.; Souza, A.; Farrell, L.; Pollak, M.R.; Lewis, G.D.; Steele, D.J.; Thadhani, R.; Clish, C.B.; Greka, A.; Gerszten, R.E. Metabolite profiling identifies markers of uremia. J. Am. Soc. Nephrol. JASN 2010, 21, 1041-1051. [CrossRef] [PubMed]

10. Kikuchi, K.; Itoh, Y.; Tateoka, R.; Ezawa, A.; Murakami, K.; Niwa, T. Metabolomic analysis of uremic toxins by liquid chromatography/electrospray ionization-tandem mass spectrometry. J. Chromatogr. B Anal. Technol. Biomed. Life Sci. 2010, 878, 1662-1668. [CrossRef] [PubMed]

11. Sato, E.; Kohno, M.; Yamamoto, M.; Fujisawa, T.; Fujiwara, K.; Tanaka, N. Metabolomic analysis of human plasma from haemodialysis patients. Eur. J. Clin. Investig. 2011, 41, 241-255. [CrossRef] [PubMed]

12. Toyohara, T.; Akiyama, Y.; Suzuki, T.; Takeuchi, Y.; Mishima, E.; Tanemoto, M.; Momose, A.; Toki, N.; Sato, H.; Nakayama, M.; et al. Metabolomic profiling of uremic solutes in ckd patients. Hypertens. Res. Off. J. Jpn. Soc. Hypertens. 2010, 33, 944-952. [CrossRef] [PubMed]

13. Mutsaers, H.A.; van den Heuvel, L.P.; Ringens, L.H.; Dankers, A.C.; Russel, F.G.; Wetzels, J.F.; Hoenderop, J.G.; Masereeuw, R. Uremic toxins inhibit transport by breast cancer resistance protein and multidrug resistance protein 4 at clinically relevant concentrations. PLoS ONE 2011, 6, e18438. [CrossRef] [PubMed]

14. Tanaka, H.; Sirich, T.L.; Plummer, N.S.; Weaver, D.S.; Meyer, T.W. An enlarged profile of uremic solutes. PLoS ONE 2015, 10, e0135657. [CrossRef] [PubMed]

15. Mishima, E.; Fukuda, S.; Mukawa, C.; Yuri, A.; Kanemitsu, Y.; Matsumoto, Y.; Akiyama, Y.; Fukuda, N.N.; Tsukamoto, H.; Asaji, K.; et al. Evaluation of the impact of gut microbiota on uremic solute accumulation by a ce-tofms-based metabolomics approach. Kidney Int. 2017, 92, 634-645. [CrossRef] [PubMed]

16. Vanholder, R.; Argiles, A.; Baurmeister, U.; Brunet, P.; Clark, W.; Cohen, G.; De Deyn, P.P.; Deppisch, R.; Descamps-Latscha, B.; Henle, T.; et al. Uremic toxicity: Present state of the art. Int. J. Artif. Organs 2001, 24, 695-725. [PubMed]

17. Meijers, B.; Glorieux, G.; Poesen, R.; Bakker, S.J. Nonextracorporeal methods for decreasing uremic solute concentration: A future way to go? Semin. Nephrol. 2014, 34, 228-243. [CrossRef] [PubMed]

18. Schepers, E.; Speer, T.; Bode-Boger, S.M.; Fliser, D.; Kielstein, J.T. Dimethylarginines adma and sdma: The real water-soluble small toxins? Semin. Nephrol. 2014, 34, 97-105. [CrossRef] [PubMed]

19. Meert, N.; Schepers, E.; Glorieux, G.; Van Landschoot, M.; Goeman, J.L.; Waterloos, M.A.; Dhondt, A.; Van der Eycken, J.; Vanholder, R. Novel method for simultaneous determination of p-cresylsulphate and p-cresylglucuronide: Clinical data and pathophysiological implications. Nephrol. Dial. Transplant. 2012, 27, 2388-2396. [CrossRef] [PubMed]

20. Vanholder, R.; Schepers, E.; Pletinck, A.; Nagler, E.V.; Glorieux, G. The uremic toxicity of indoxyl sulfate and p-cresyl sulfate: A systematic review. J. Am. Soc. Nephrol. JASN 2014, 25, 1897-1907. [CrossRef] [PubMed]

21. Eloot, S.; Torremans, A.; De Smet, R.; Marescau, B.; De Wachter, D.; De Deyn, P.P.; Lameire, N.; Verdonck, P.; Vanholder, R. Kinetic behavior of urea is different from that of other water-soluble compounds: The case of the guanidino compounds. Kidney Int. 2005, 67, 1566-1575. [CrossRef] [PubMed]

22. Vanholder, R.C.; Eloot, S.; Glorieux, G.L. Future avenues to decrease uremic toxin concentration. Am. J. Kidney Dis. 2016, 67, 664-676. [CrossRef] [PubMed]

23. Vanholder, R.C.; Glorieux, G.; De Smet, R.; De Deyn, P.P. Low water-soluble uremic toxins. Adv. Ren. Replace Ther. 2003, 10, 257-269. [CrossRef] [PubMed]

24. De Deyn, P.P.; Vanholder, R.; Eloot, S.; Glorieux, G. Guanidino compounds as uremic (neuro)toxins. Semin. Dial. 2009, 22, 340-345. [CrossRef] [PubMed]

25. D’Hooge, R.; Van de Vijver, G.; Van Bogaert, P.P.; Marescau, B.; Vanholder, R.; De Deyn, P.P. Involvement of voltage- and ligand-gated $\mathrm{Ca}^{2+}$ channels in the neuroexcitatory and synergistic effects of putative uremic neurotoxins. Kidney Int. 2003, 63, 1764-1775. [CrossRef] [PubMed] 
26. Pan, J.C.; Pei, Y.Q.; An, L.; Lai, L.; D’Hooge, R.; De Deyn, P.P. Epileptiform activity and hippocampal damage produced by intrahippocampal injection of guanidinosuccinic acid in rat. Neurosci. Lett. 1996, 209, 121-124. [CrossRef]

27. Torremans, A.; Marescau, B.; Van Dam, D.; Van Ginneken, C.; Van Meir, F.; Van Bogaert, P.P.; D’Hooge, R.; de Vente, J.; De Deyn, P.P. Gsa: Behavioral, histological, electrophysiological and neurochemical effects. Physiol. Behav. 2005, 84, 251-264. [CrossRef] [PubMed]

28. Glorieux, G.L.; Dhondt, A.W.; Jacobs, P.; Van Langeraert, J.; Lameire, N.H.; De Deyn, P.P.; Vanholder, R.C. In vitro study of the potential role of guanidines in leukocyte functions related to atherogenesis and infection. Kidney Int. 2004, 65, 2184-2192. [CrossRef] [PubMed]

29. Schepers, E.; Glorieux, G.; Dou, L.; Cerini, C.; Gayrard, N.; Louvet, L.; Maugard, C.; Preus, P.; Rodriguez-Ortiz, M.; Argiles, A.; et al. Guanidino compounds as cause of cardiovascular damage in chronic kidney disease: An in vitro evaluation. Blood Purif. 2010, 30, 277-287. [CrossRef] [PubMed]

30. Patel, S.; Hsu, C.H. Effect of polyamines, methylguanidine, and guanidinosuccinic acid on calcitriol synthesis. J. Lab. Clin. Med. 1990, 115, 69-73. [PubMed]

31. Rueth, M.; Lemke, H.D.; Preisinger, C.; Krieter, D.; Theelen, W.; Gajjala, P.; Devine, E.; Zidek, W.; Jankowski, J.; Jankowski, V. Guanidinylations of albumin decreased binding capacity of hydrophobic metabolites. Acta Physiol. 2015, 215, 13-23. [CrossRef] [PubMed]

32. Eloot, S.; Torremans, A.; De Smet, R.; Marescau, B.; De Deyn, P.P.; Verdonck, P.; Vanholder, R. Complex compartmental behavior of small water-soluble uremic retention solutes: Evaluation by direct measurements in plasma and erythrocytes. Am. J. Kidney Dis. 2007, 50, 279-288. [CrossRef] [PubMed]

33. Vallance, P.; Leone, A.; Calver, A.; Collier, J.; Moncada, S. Accumulation of an endogenous inhibitor of nitric oxide synthesis in chronic renal failure. Lancet 1992, 339, 572-575. [PubMed]

34. Schwedhelm, E.; Boger, R.H. The role of asymmetric and symmetric dimethylarginines in renal disease. Nat. Rev. Nephrol. 2011, 7, 275-285. [CrossRef] [PubMed]

35. Tain, Y.L.; Hsu, C.N. Toxic dimethylarginines: Asymmetric dimethylarginine (adma) and symmetric dimethylarginine (sdma). Toxins 2017, 9, 92. [CrossRef] [PubMed]

36. Valkonen, V.P.; Paiva, H.; Salonen, J.T.; Lakka, T.A.; Lehtimaki, T.; Laakso, J.; Laaksonen, R. Risk of acute coronary events and serum concentration of asymmetrical dimethylarginine. Lancet 2001, 358, 2127-2128. [CrossRef]

37. Meinitzer, A.; Seelhorst, U.; Wellnitz, B.; Halwachs-Baumann, G.; Boehm, B.O.; Winkelmann, B.R.; Marz, W. Asymmetrical dimethylarginine independently predicts total and cardiovascular mortality in individuals with angiographic coronary artery disease (the ludwigshafen risk and cardiovascular health study). Clin. Chem. 2007, 53, 273-283. [CrossRef] [PubMed]

38. Zoccali, C.; Bode-Boger, S.; Mallamaci, F.; Benedetto, F.; Tripepi, G.; Malatino, L.; Cataliotti, A.; Bellanuova, I.; Fermo, I.; Frolich, J.; et al. Plasma concentration of asymmetrical dimethylarginine and mortality in patients with end-stage renal disease: A prospective study. Lancet 2001, 358, 2113-2117. [CrossRef]

39. Shafi, T.; Hostetter, T.H.; Meyer, T.W.; Hwang, S.; Hai, X.; Melamed, M.L.; Banerjee, T.; Coresh, J.; Powe, N.R. Serum asymmetric and symmetric dimethylarginine and morbidity and mortality in hemodialysis patients. Am. J. Kidney Dis. 2017, 70, 48-58. [CrossRef] [PubMed]

40. Von Leitner, E.C.; Klinke, A.; Atzler, D.; Slocum, J.L.; Lund, N.; Kielstein, J.T.; Maas, R.; Schmidt-Haupt, R.; Pekarova, M.; Hellwinkel, O.; et al. Pathogenic cycle between the endogenous nitric oxide synthase inhibitor asymmetrical dimethylarginine and the leukocyte-derived hemoprotein myeloperoxidase. Circulation 2011, 124, 2735-2745. [CrossRef] [PubMed]

41. Kielstein, J.T.; Impraim, B.; Simmel, S.; Bode-Boger, S.M.; Tsikas, D.; Frolich, J.C.; Hoeper, M.M.; Haller, H.; Fliser, D. Cardiovascular effects of systemic nitric oxide synthase inhibition with asymmetrical dimethylarginine in humans. Circulation 2004, 109, 172-177. [CrossRef] [PubMed]

42. Grassi, G.; Seravalle, G.; Trevano, F.Q.; Spaziani, D.; Scalise, F.; Auguadro, C.; Pizzini, P.; Tripepi, G.; D'Arrigo, G.; Mallamaci, F.; et al. Asymmetric and symmetric dimethylarginine and sympathetic nerve traffic after renal denervation in patients with resistant hypertension. Clin. J. Am. Soc. Nephrol. CJASN 2015, 10, 1560-1567. [CrossRef] [PubMed]

43. Miralbell, J.; Lopez-Cancio, E.; Lopez-Oloriz, J.; Arenillas, J.F.; Barrios, M.; Soriano-Raya, J.J.; Galan, A.; Caceres, C.; Alzamora, M.; Pera, G.; et al. Cognitive patterns in relation to biomarkers of cerebrovascular disease and vascular risk factors. Cerebrovasc. Dis. 2013, 36, 98-105. [CrossRef] [PubMed] 
44. McEvoy, M.A.; Schofield, P.; Smith, W.; Agho, K.; Mangoni, A.A.; Soiza, R.L.; Peel, R.; Hancock, S.; Kelly, B.; Inder, K.; et al. Serum methylarginines and incident depression in a cohort of older adults. J. Affect. Disord. 2013, 151, 493-499. [CrossRef] [PubMed]

45. Yokoro, M.; Nakayama, Y.; Yamagishi, S.I.; Ando, R.; Sugiyama, M.; Ito, S.; Yano, J.; Taguchi, K.; Kaida, Y.; Saigusa, D.; et al. Asymmetric dimethylarginine contributes to the impaired response to erythropoietin in ckd-anemia. J. Am. Soc. Nephrol. JASN 2017, 28, 2670-2680. [CrossRef] [PubMed]

46. Tanaka, M.; Sydow, K.; Gunawan, F.; Jacobi, J.; Tsao, P.S.; Robbins, R.C.; Cooke, J.P. Dimethylarginine dimethylaminohydrolase overexpression suppresses graft coronary artery disease. Circulation 2005, 112, 1549-1556. [CrossRef] [PubMed]

47. Bode-Boger, S.M.; Scalera, F.; Kielstein, J.T.; Martens-Lobenhoffer, J.; Breithardt, G.; Fobker, M.; Reinecke, H. Symmetrical dimethylarginine: A new combined parameter for renal function and extent of coronary artery disease. J. Am. Soc. Nephrol. JASN 2006, 17, 1128-1134. [CrossRef] [PubMed]

48. Schepers, E.; Barreto, D.V.; Liabeuf, S.; Glorieux, G.; Eloot, S.; Barreto, F.C.; Massy, Z.; Vanholder, R.; European Uremic Toxin Work Group. Symmetric dimethylarginine as a proinflammatory agent in chronic kidney disease. Clin. J. Am. Soc. Nephrol. CJASN 2011, 6, 2374-2383. [CrossRef] [PubMed]

49. Speer, T.; Rohrer, L.; Blyszczuk, P.; Shroff, R.; Kuschnerus, K.; Krankel, N.; Kania, G.; Zewinger, S.; Akhmedov, A.; Shi, Y.; et al. Abnormal high-density lipoprotein induces endothelial dysfunction via activation of toll-like receptor-2. Immunity 2013, 38, 754-768. [CrossRef] [PubMed]

50. Gore, M.O.; Luneburg, N.; Schwedhelm, E.; Ayers, C.R.; Anderssohn, M.; Khera, A.; Atzler, D.; de Lemos, J.A.; Grant, P.J.; McGuire, D.K.; et al. Symmetrical dimethylarginine predicts mortality in the general population: Observations from the dallas heart study. Arterioscler. Thromb. Vasc. Biol. 2013, 33, 2682-2688. [CrossRef] [PubMed]

51. Schwedhelm, E.; Wallaschofski, H.; Atzler, D.; Dorr, M.; Nauck, M.; Volker, U.; Kroemer, H.K.; Volzke, H.; Boger, R.H.; Friedrich, N. Incidence of all-cause and cardiovascular mortality predicted by symmetric dimethylarginine in the population-based study of health in pomerania. PLOS ONE 2014, 9, e96875. [CrossRef] [PubMed]

52. Cochat, P.; Rumsby, G. Primary hyperoxaluria. N. Engl. J. Med. 2013, 369, 649-658. [CrossRef] [PubMed]

53. Salyer, W.R.; Keren, D. Oxalosis as a complication of chronic renal failure. Kidney Int. 1973, 4, 61-66. [CrossRef] [PubMed]

54. Worcester, E.M.; Nakagawa, Y.; Bushinsky, D.A.; Coe, F.L. Evidence that serum calcium oxalate supersaturation is a consequence of oxalate retention in patients with chronic renal failure. J. Clin. Investig. 1986, 77, 1888-1896. [CrossRef] [PubMed]

55. Recht, P.A.; Tepedino, G.J.; Siecke, N.W.; Buckley, M.T.; Mandeville, J.T.; Maxfield, F.R.; Levin, R.I. Oxalic acid alters intracellular calcium in endothelial cells. Atherosclerosis 2004, 173, 321-328. [CrossRef] [PubMed]

56. Levin, R.I.; Kantoff, P.W.; Jaffe, E.A. Uremic levels of oxalic acid suppress replication and migration of human endothelial cells. Arteriosclerosis 1990, 10, 198-207. [CrossRef] [PubMed]

57. Mutsaers, H.A.; Wilmer, M.J.; Reijnders, D.; Jansen, J.; van den Broek, P.H.; Forkink, M.; Schepers, E.; Glorieux, G.; Vanholder, R.; van den Heuvel, L.P.; et al. Uremic toxins inhibit renal metabolic capacity through interference with glucuronidation and mitochondrial respiration. Biochim. Biophys. Acta 2013, 1832, 142-150. [CrossRef] [PubMed]

58. Zimmerman, L.; Jornvall, H.; Bergstrom, J. Phenylacetylglutamine and hippuric acid in uremic and healthy subjects. Nephron 1990, 55, 265-271. [CrossRef] [PubMed]

59. Shafi, T.; Meyer, T.W.; Hostetter, T.H.; Melamed, M.L.; Parekh, R.S.; Hwang, S.; Banerjee, T.; Coresh, J.; Powe, N.R. Free levels of selected organic solutes and cardiovascular morbidity and mortality in hemodialysis patients: Results from the retained organic solutes and clinical outcomes (rosco) investigators. PLoS ONE 2015, 10, e0126048. [CrossRef] [PubMed]

60. Poesen, R.; Claes, K.; Evenepoel, P.; de Loor, H.; Augustijns, P.; Kuypers, D.; Meijers, B. Microbiota-derived phenylacetylglutamine associates with overall mortality and cardiovascular disease in patients with ckd. J. Am. Soc. Nephrol. JASN 2016, 27, 3479-3487. [CrossRef] [PubMed]

61. Kurella Tamura, M.; Chertow, G.M.; Depner, T.A.; Nissenson, A.R.; Schiller, B.; Mehta, R.L.; Liu, S.; Sirich, T.L.; Study, F.H.N. Metabolic profiling of impaired cognitive function in patients receiving dialysis. J. Am. Soc. Nephrol. JASN 2016, 27, 3780-3787. [CrossRef] [PubMed] 
62. Wang, X.; Jiang, C.M.; Wan, H.Y.; Wu, J.L.; Quan, W.Q.; Bals, R.; Wu, K.Y.; Li, D. Cda-2, a urinary preparation, inhibits lung cancer development through the suppression of nf-kappab activation in myeloid cell. PLOS ONE 2012, 7, e52117. [CrossRef] [PubMed]

63. Hur, E.; Gungor, O.; Bozkurt, D.; Bozgul, S.; Dusunur, F.; Caliskan, H.; Berdeli, A.; Akcicek, F.; Basci, A.; Duman, S. Trimethylaminuria (fish malodour syndrome) in chronic renal failure. Hippokratia 2012, 16, 83-85. [PubMed]

64. Simenhoff, M.L.; Saukkonen, J.J.; Burke, J.F.; Schaedler, R.W.; Vogel, W.H.; Bovee, K.; Lasker, N. Importance of aliphatic amines in uremia. Kidney Int. Suppl. 1978, S16-S19.

65. Yu, P.H.; Deng, Y.L. Endogenous formaldehyde as a potential factor of vulnerability of atherosclerosis: Involvement of semicarbazide-sensitive amine oxidase-mediated methylamine turnover. Atherosclerosis 1998, 140, 357-363. [CrossRef]

66. Cheung, K.W.K.; Hsueh, C.H.; Zhao, P.; Meyer, T.W.; Zhang, L.; Huang, S.M.; Giacomini, K.M. The effect of uremic solutes on the organic cation transporter 2. J. Pharm. Sci. 2017, 106, 2551-2557. [CrossRef] [PubMed]

67. Melamed, M.L.; Plantinga, L.; Shafi, T.; Parekh, R.; Meyer, T.W.; Hostetter, T.H.; Coresh, J.; Powe, N.R. Retained organic solutes, patient characteristics and all-cause and cardiovascular mortality in hemodialysis: Results from the retained organic solutes and clinical outcomes (rosco) investigators. BMC Nephrol. 2013, 14, 134. [CrossRef] [PubMed]

68. Raff, A.C.; Lieu, S.; Melamed, M.L.; Quan, Z.; Ponda, M.; Meyer, T.W.; Hostetter, T.H. Relationship of impaired olfactory function in esrd to malnutrition and retained uremic molecules. Am. J. Kidney Dis. 2008, 52, 102-110. [CrossRef] [PubMed]

69. Lindner, A.; Vanholder, R.; De Smet, R.; Hinds, T.R.; Vogeleere, P.; Sandra, P.; Foxall, P.; Ringoir, S. Hplc fractions of human uremic plasma inhibit the rbc membrane calcium pump. Kidney Int. 1997, 51, 1042-1052. [CrossRef] [PubMed]

70. Wang, Z.; Klipfell, E.; Bennett, B.J.; Koeth, R.; Levison, B.S.; Dugar, B.; Feldstein, A.E.; Britt, E.B.; $\mathrm{Fu}, \mathrm{X} . ;$ Chung, Y.M.; et al. Gut flora metabolism of phosphatidylcholine promotes cardiovascular disease. Nature 2011, 472, 57-63. [CrossRef] [PubMed]

71. Velasquez, M.T.; Ramezani, A.; Manal, A.; Raj, D.S. Trimethylamine n-oxide: The good, the bad and the unknown. Toxins 2016, 8, 326. [CrossRef] [PubMed]

72. Ma, J.; Pazos, I.M.; Gai, F. Microscopic insights into the protein-stabilizing effect of trimethylamine n-oxide (tmao). Proc. Natl. Acad. Sci. USA 2014, 111, 8476-8481. [CrossRef] [PubMed]

73. Griffin, J.L.; Wang, X.; Stanley, E. Does our gut microbiome predict cardiovascular risk? A review of the evidence from metabolomics. Circ. Cardiovasc. Genet. 2015, 8, 187-191. [CrossRef] [PubMed]

74. Meinardi, S.; Jin, K.B.; Barletta, B.; Blake, D.R.; Vaziri, N.D. Exhaled breath and fecal volatile organic biomarkers of chronic kidney disease. Biochim. Biophys. Acta 2013, 1830, 2531-2537. [CrossRef] [PubMed]

75. Perna, A.F.; Di Nunzio, A.; Amoresano, A.; Pane, F.; Fontanarosa, C.; Pucci, P.; Vigorito, C.; Cirillo, G.; Zacchia, M.; Trepiccione, F.; et al. Divergent behavior of hydrogen sulfide pools and of the sulfur metabolite lanthionine, a novel uremic toxin, in dialysis patients. Biochimie 2016, 126, 97-107. [CrossRef] [PubMed]

76. Perna, A.F.; Sepe, I.; Lanza, D.; Capasso, R.; Zappavigna, S.; Capasso, G.; Caraglia, M.; Ingrosso, D. Hydrogen sulfide reduces cell adhesion and relevant inflammatory triggering by preventing adam17-dependent tnf-alpha activation. J. Cell. Biochem. 2013, 114, 1536-1548. [CrossRef] [PubMed]

77. Wen, Y.D.; Wang, H.; Kho, S.H.; Rinkiko, S.; Sheng, X.; Shen, H.M.; Zhu, Y.Z. Hydrogen sulfide protects huvecs against hydrogen peroxide induced mitochondrial dysfunction and oxidative stress. PLOS ONE 2013, 8, e53147. [CrossRef] [PubMed]

78. Jankowski, J.; Westhof, T.; Vaziri, N.D.; Ingrosso, D.; Perna, A.F. Gases as uremic toxins: Is there something in the air? Semin. Nephrol. 2014, 34, 135-150. [CrossRef] [PubMed]

79. Perna, A.F.; Zacchia, M.; Trepiccione, F.; Ingrosso, D. The sulfur metabolite lanthionine: Evidence for a role as a novel uremic toxin. Toxins 2017, 9, 26. [CrossRef] [PubMed]

80. Niwa, T.; Sobue, G.; Maeda, K.; Mitsuma, T. Myoinositol inhibits proliferation of cultured schwann cells: Evidence for neurotoxicity of myoinositol. Nephrol. Dial. Transplant. 1989, 4, 662-666. [PubMed]

81. Clements, R.S., Jr.; DeJesus, P.V., Jr.; Winegrad, A.I. Raised plasma-myoinositol levels in uraemia and experimental neuropathy. Lancet 1973, 1, 1137-1141. [CrossRef] 
82. Torremans, A.; D’Hooge, R.; Van de Vijver, G.; Marescau, B.; Vanholder, R.; Lameire, N.; De Deyn, P.P.; Van Bogaert, P.P. Effect of nacn on currents evoked by uremic retention solutes in dissociated mouse neurons. Brain Res. 2004, 1008, 107-112. [CrossRef] [PubMed]

83. Croze, M.L.; Soulage, C.O. Potential role and therapeutic interests of myo-inositol in metabolic diseases. Biochimie 2013, 95, 1811-1827. [CrossRef] [PubMed]

84. Rutkowski, B.; Slominska, E.; Szolkiewicz, M.; Smolenski, R.T.; Striley, C.; Rutkowski, P.; Swierczynski, J. N-methyl-2-pyridone-5-carboxamide: A novel uremic toxin? Kidney Int. Suppl. 2003, S19-S21. [CrossRef] [PubMed]

85. Lenglet, A.; Liabeuf, S.; Bodeau, S.; Louvet, L.; Mary, A.; Boullier, A.; Lemaire-Hurtel, A.S.; Jonet, A.; Sonnet, P.; Kamel, S.; et al. N-methyl-2-pyridone-5-carboxamide (2py)-major metabolite of nicotinamide: An update on an old uremic toxin. Toxins 2016, 8, 339. [CrossRef] [PubMed]

86. Lenglet, A.; Liabeuf, S.; El Esper, N.; Brisset, S.; Mansour, J.; Lemaire-Hurtel, A.S.; Mary, A.; Brazier, M.; Kamel, S.; Mentaverri, R.; et al. Efficacy and safety of nicotinamide in haemodialysis patients: The nicoren study. Nephrol. Dial. Transplant. 2016, 32, 870-879. [CrossRef] [PubMed]

87. Sindhu, K.K. Uremic toxins: Some thoughts on acrolein and spermine. Ren. Fail. 2016, 38, 1755-1758. [CrossRef] [PubMed]

88. Sakata, K.; Kashiwagi, K.; Sharmin, S.; Ueda, S.; Igarashi, K. Acrolein produced from polyamines as one of the uraemic toxins. Biochem. Soc. Trans. 2003, 31, 371-374. [CrossRef] [PubMed]

89. Sharmin, S.; Sakata, K.; Kashiwagi, K.; Ueda, S.; Iwasaki, S.; Shirahata, A.; Igarashi, K. Polyamine cytotoxicity in the presence of bovine serum amine oxidase. Biochem. Biophys. Res. Commun. 2001, 282, 228-235. [CrossRef] [PubMed]

90. Galli, F.; Beninati, S.; Benedetti, S.; Lentini, A.; Canestrari, F.; Tabilio, A.; Buoncristiani, U. Polymeric protein-polyamine conjugates: A new class of uremic toxins affecting erythropoiesis. Kidney Int. Suppl. 2001, 78, S73-S76. [CrossRef] [PubMed]

91. Kushner, D.; Beckman, B.; Nguyen, L.; Chen, S.; Della Santina, C.; Husserl, F.; Rice, J.; Fisher, J.W. Polyamines in the anemia of end-stage renal disease. Kidney Int. 1991, 39, 725-732. [CrossRef] [PubMed]

92. Radtke, H.W.; Rege, A.B.; LaMarche, M.B.; Bartos, D.; Bartos, F.; Campbell, R.A.; Fisher, J.W. Identification of spermine as an inhibitor of erythropoiesis in patients with chronic renal failure. J. Clin. Investig. 1981, 67, 1623-1629. [CrossRef] [PubMed]

93. Yoshida, K.; Yoneda, T.; Kimura, S.; Fujimoto, K.; Okajima, E.; Hirao, Y. Polyamines as an inhibitor on erythropoiesis of hemodialysis patients by in vitro bioassay using the fetal mouse liver assay. Ther. Apheresis Dial. 2006, 10, 267-272. [CrossRef] [PubMed]

94. Szabo, C.; Southan, G.J.; Wood, E.; Thiemermann, C.; Vane, J.R. Inhibition by spermine of the induction of nitric oxide synthase in j774.2 macrophages: Requirement of a serum factor. Br. J. Pharmacol. 1994, 112, 355-356. [CrossRef] [PubMed]

95. Sinha-Hikim, I.; Shen, R.; Paul Lee, W.N.; Crum, A.; Vaziri, N.D.; Norris, K.C. Effects of a novel cystine-based glutathione precursor on oxidative stress in vascular smooth muscle cells. Am. J. Physiol. Cell Physiol. 2010, 299, 638-642. [CrossRef] [PubMed]

96. De la Pena, N.C.; Sosa-Melgarejo, J.A.; Ramos, R.R.; Mendez, J.D. Inhibition of platelet aggregation by putrescine, spermidine, and spermine in hypercholesterolemic rabbits. Arch. Med. Res. 2000, 31, 546-550. [CrossRef]

97. Rock, D.M.; MacDonald, R.L. Spermine and related polyamines produce a voltage-dependent reduction of n-methyl-d-aspartate receptor single-channel conductance. Mol. Pharmacol. 1992, 42, 157-164. [PubMed]

98. Sparapani, M.; Dall'Olio, R.; Gandolfi, O.; Ciani, E.; Contestabile, A. Neurotoxicity of polyamines and pharmacological neuroprotection in cultures of rat cerebellar granule cells. Exp. Neurol. 1997, 148, 157-166. [CrossRef] [PubMed]

99. Fahey, J.M.; Pritchard, G.A.; Miller, L.G. Polyamine neurotoxicity is antagonized by dizocilpine in cultured chick cortical neurons. Neurosci. Lett. 1993, 161, 109-112. [CrossRef]

100. Bourdiol, F.; Fage, D.; Serrano, A.; Carter, C.; Benavides, J.; Scatton, B. Neurotoxic effects of the intrastriatal injection of spermine and spermidine: Lack of involvement of nmda receptors. Brain Res. 1992, 596, $183-188$. [CrossRef]

101. Segal, J.A.; Skolnick, P. Spermine-induced toxicity in cerebellar granule neurons is independent of its actions at nmda receptors. J. Neurochem. 2000, 74, 60-69. [CrossRef] [PubMed] 
102. Stabellini, G.; Mariani, G.; Pezzetti, F.; Calastrini, C. Direct inhibitory effect of uremic toxins and polyamines on proliferation of vero culture cells. Exp. Mol. Pathol. 1997, 64, 147-155. [CrossRef] [PubMed]

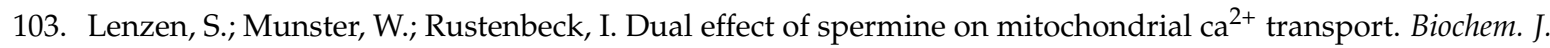
1992, 286 Pt 2, 597-602. [CrossRef] [PubMed]

104. Lenzen, S.; Rustenbeck, I. Effects of $\mathrm{ip}_{3}$, spermine, and $\mathrm{mg}^{2+}$ on regulation of $\mathrm{ca}^{2+}$ transport by endoplasmic reticulum and mitochondria in permeabilized pancreatic islets. Diabetes 1991, 40, 323-326. [CrossRef] [PubMed]

105. Schophuizen, C.M.; Wilmer, M.J.; Jansen, J.; Gustavsson, L.; Hilgendorf, C.; Hoenderop, J.G.; van den Heuvel, L.P.; Masereeuw, R. Cationic uremic toxins affect human renal proximal tubule cell functioning through interaction with the organic cation transporter. Pflugers Arch. Eur. J. Physiol. 2013, 465, 1701-1714. [CrossRef] [PubMed]

106. Noro, T.; Namekata, K.; Kimura, A.; Guo, X.; Azuchi, Y.; Harada, C.; Nakano, T.; Tsuneoka, H.; Harada, T. Spermidine promotes retinal ganglion cell survival and optic nerve regeneration in adult mice following optic nerve injury. Cell Death Dis. 2015, 6, e1720. [CrossRef] [PubMed]

107. Kaasinen, K.; Koistinaho, J.; Alhonen, L.; Janne, J. Overexpression of spermidine/spermine n-acetyltransferase in transgenic mice protects the animals from kainate-induced toxicity. Eur. J. Neurosci. 2000, 12, 540-548. [CrossRef] [PubMed]

108. Ha, H.C.; Sirisoma, N.S.; Kuppusamy, P.; Zweier, J.L.; Woster, P.M.; Casero, R.A., Jr. The natural polyamine spermine functions directly as a free radical scavenger. Proc. Natl. Acad. Sci. USA 1998, 95, 11140-11145. [CrossRef] [PubMed]

109. Vanholder, R.; Glorieux, G.; Eloot, S. Once upon a time in dialysis: The last days of kt/v? Kidney Int. 2015, 88, 460-465. [CrossRef] [PubMed]

110. Vanholder, R.; Gryp, T.; Glorieux, G. Urea and chronic kidney disease: The comeback of the century? (in uraemia research). Nephrol. Dial. Transplant. 2017. [CrossRef] [PubMed]

111. Lau, W.L.; Vaziri, N.D. Urea, a true uremic toxin: The empire strikes back. Clin. Sci. 2017, 131, 3-12. [CrossRef] [PubMed]

112. Massy, Z.A.; Pietrement, C.; Toure, F. Reconsidering the lack of urea toxicity in dialysis patients. Semin. Dial. 2016, 29, 333-337. [CrossRef] [PubMed]

113. D'Apolito, M.; Du, X.; Zong, H.; Catucci, A.; Maiuri, L.; Trivisano, T.; Pettoello-Mantovani, M.; Campanozzi, A.; Raia, V.; Pessin, J.E.; et al. Urea-induced ros generation causes insulin resistance in mice with chronic renal failure. J. Clin. Investig. 2010, 120, 203-213. [CrossRef] [PubMed]

114. Koppe, L.; Nyam, E.; Vivot, K.; Manning Fox, J.E.; Dai, X.Q.; Nguyen, B.N.; Trudel, D.; Attane, C.; Moulle, V.S.; MacDonald, P.E.; et al. Urea impairs beta cell glycolysis and insulin secretion in chronic kidney disease. J. Clin. Investig. 2016, 126, 3598-3612. [CrossRef] [PubMed]

115. D'Apolito, M.; Du, X.; Pisanelli, D.; Pettoello-Mantovani, M.; Campanozzi, A.; Giacco, F.; Maffione, A.B.; Colia, A.L.; Brownlee, M.; Giardino, I. Urea-induced ros cause endothelial dysfunction in chronic renal failure. Atherosclerosis 2015, 239, 393-400. [CrossRef] [PubMed]

116. Trecherel, E.; Godin, C.; Louandre, C.; Benchitrit, J.; Poirot, S.; Maziere, J.C.; Massy, Z.A.; Galmiche, A. Upregulation of bad, a pro-apoptotic protein of the bcl2 family, in vascular smooth muscle cells exposed to uremic conditions. Biochem. Biophys. Res. Commun. 2012, 417, 479-483. [CrossRef] [PubMed]

117. Vaziri, N.D.; Yuan, J.; Norris, K. Role of urea in intestinal barrier dysfunction and disruption of epithelial tight junction in chronic kidney disease. Am. J. Nephrol. 2013, 37, 1-6. [CrossRef] [PubMed]

118. Eknoyan, G.; Beck, G.J.; Cheung, A.K.; Daugirdas, J.T.; Greene, T.; Kusek, J.W.; Allon, M.; Bailey, J.; Delmez, J.A.; Depner, T.A.; et al. Effect of dialysis dose and membrane flux in maintenance hemodialysis. N. Engl. J. Med. 2002, 347, 2010-2019. [CrossRef] [PubMed]

119. Meijers, B.; Vanholder, R. Hemo revisited: Why kt/vurea only tells part of the story. J. Am. Soc. Nephrol. JASN 2016, 27, 3235-3237. [CrossRef] [PubMed]

120. Saran, R.; Bragg-Gresham, J.L.; Levin, N.W.; Twardowski, Z.J.; Wizemann, V.; Saito, A.; Kimata, N.; Gillespie, B.W.; Combe, C.; Bommer, J.; et al. Longer treatment time and slower ultrafiltration in hemodialysis: Associations with reduced mortality in the dopps. Kidney Int. 2006, 69, 1222-1228. [CrossRef] [PubMed]

121. Meyer, T.W.; Sirich, T.L.; Fong, K.D.; Plummer, N.S.; Shafi, T.; Hwang, S.; Banerjee, T.; Zhu, Y.; Powe, N.R.; Hai, X.; et al. Kt/vurea and nonurea small solute levels in the hemodialysis study. J. Am. Soc. Nephrol. JASN 2016, 27, 3469-3478. [CrossRef] [PubMed] 
122. Delanghe, S.; Delanghe, J.R.; Speeckaert, R.; Van Biesen, W.; Speeckaert, M.M. Mechanisms and consequences of carbamoylation. Nat. Rev. Nephrol. 2017, 13, 580-593. [CrossRef] [PubMed]

123. Shaykh, M.; Pegoraro, A.A.; Mo, W.; Arruda, J.A.; Dunea, G.; Singh, A.K. Carbamylated proteins activate glomerular mesangial cells and stimulate collagen deposition. J. Lab. Clin. Med. 1999, 133, 302-308. [CrossRef]

124. Jaisson, S.; Lorimier, S.; Ricard-Blum, S.; Sockalingum, G.D.; Delevallee-Forte, C.; Kegelaer, G.; Manfait, M.; Garnotel, R.; Gillery, P. Impact of carbamylation on type i collagen conformational structure and its ability to activate human polymorphonuclear neutrophils. Chem. Biol. 2006, 13, 149-159. [CrossRef] [PubMed]

125. Ok, E.; Basnakian, A.G.; Apostolov, E.O.; Barri, Y.M.; Shah, S.V. Carbamylated low-density lipoprotein induces death of endothelial cells: A link to atherosclerosis in patients with kidney disease. Kidney Int. 2005, 68, 173-178. [CrossRef] [PubMed]

126. Apostolov, E.O.; Shah, S.V.; Ok, E.; Basnakian, A.G. Carbamylated low-density lipoprotein induces monocyte adhesion to endothelial cells through intercellular adhesion molecule-1 and vascular cell adhesion molecule-1. Arterioscler. Thromb. Vasc. Biol. 2007, 27, 826-832. [CrossRef] [PubMed]

127. Sun, J.T.; Yang, K.; Lu, L.; Zhu, Z.B.; Zhu, J.Z.; Ni, J.W.; Han, H.; Chen, N.; Zhang, R.Y. Increased carbamylation level of hdl in end-stage renal disease: Carbamylated-hdl attenuated endothelial cell function. Am. J. Physiol. Ren. Physiol. 2016, 310, F511-F517. [CrossRef] [PubMed]

128. Berg, A.H.; Drechsler, C.; Wenger, J.; Buccafusca, R.; Hod, T.; Kalim, S.; Ramma, W.; Parikh, S.M.; Steen, H.; Friedman, D.J.; et al. Carbamylation of serum albumin as a risk factor for mortality in patients with kidney failure. Sci. Trans. Med. 2013, 5, 175ra129. [CrossRef] [PubMed]

129. Drechsler, C.; Kalim, S.; Wenger, J.B.; Suntharalingam, P.; Hod, T.; Thadhani, R.I.; Karumanchi, S.A.; Wanner, C.; Berg, A.H. Protein carbamylation is associated with heart failure and mortality in diabetic patients with end-stage renal disease. Kidney Int. 2015, 87, 1201-1208. [CrossRef] [PubMed]

130. Koeth, R.A.; Kalantar-Zadeh, K.; Wang, Z.; Fu, X.; Tang, W.H.; Hazen, S.L. Protein carbamylation predicts mortality in esrd. J. Am. Soc. Nephrol. JASN 2013, 24, 853-861. [CrossRef] [PubMed]

131. Nilsson, L.; Lundquist, P.; Kagedal, B.; Larsson, R. Plasma cyanate concentrations in chronic renal failure. Clin. Chem. 1996, 42, 482-483. [PubMed]

132. El-Gamal, D.; Rao, S.P.; Holzer, M.; Hallstrom, S.; Haybaeck, J.; Gauster, M.; Wadsack, C.; Kozina, A.; Frank, S.; Schicho, R.; et al. The urea decomposition product cyanate promotes endothelial dysfunction. Kidney Int. 2014, 86, 923-931. [CrossRef] [PubMed]

133. Vaziri, N.D. Effect of synbiotic therapy on gut-derived uremic toxins and the intestinal microbiome in patients with ckd. Clin. J. Am. Soc. Nephrol. CJASN 2016, 11, 199-201. [CrossRef] [PubMed]

134. Hsu, C.H.; Patel, S.R.; Young, E.W.; Vanholder, R. Effects of purine derivatives on calcitriol metabolism in rats. Am. J. Physiol. 1991, 260, F596-F601. [CrossRef] [PubMed]

135. Vanholder, R.; Patel, S.; Hsu, C.H. Effect of uric acid on plasma levels of 1,25(oh)2d in renal failure. J. Am. Soc. Nephrol. JASN 1993, 4, 1035-1038. [PubMed]

136. Glorieux, G.; Hsu, C.H.; de Smet, R.; Dhondt, A.; van Kaer, J.; Vogeleere, P.; Lameire, N.; Vanholder, R. Inhibition of calcitriol-induced monocyte cd14 expression by uremic toxins: Role of purines. J. Am. Soc. Nephrol. JASN 1998, 9, 1826-1831. [PubMed]

137. Kanellis, J.; Watanabe, S.; Li, J.H.; Kang, D.H.; Li, P.; Nakagawa, T.; Wamsley, A.; Sheikh-Hamad, D.; Lan, H.Y.; Feng, L.; et al. Uric acid stimulates monocyte chemoattractant protein-1 production in vascular smooth muscle cells via mitogen-activated protein kinase and cyclooxygenase-2. Hypertension 2003, 41, 1287-1293. [CrossRef] [PubMed]

138. Sanchez-Lozada, L.G.; Soto, V.; Tapia, E.; Avila-Casado, C.; Sautin, Y.Y.; Nakagawa, T.; Franco, M.; Rodriguez-Iturbe, B.; Johnson, R.J. Role of oxidative stress in the renal abnormalities induced by experimental hyperuricemia. Am. J. Physiol. Ren. Physiol. 2008, 295, F1134-F1141. [CrossRef] [PubMed]

139. Corry, D.B.; Eslami, P.; Yamamoto, K.; Nyby, M.D.; Makino, H.; Tuck, M.L. Uric acid stimulates vascular smooth muscle cell proliferation and oxidative stress via the vascular renin-angiotensin system. J. Hypertens 2008, 26, 269-275. [CrossRef] [PubMed]

140. Choi, Y.J.; Yoon, Y.; Lee, K.Y.; Hien, T.T.; Kang, K.W.; Kim, K.C.; Lee, J.; Lee, M.Y.; Lee, S.M.; Kang, D.H.; et al. Uric acid induces endothelial dysfunction by vascular insulin resistance associated with the impairment of nitric oxide synthesis. FASEB J. 2014, 28, 3197-3204. [CrossRef] [PubMed] 
141. Wu, X.; Wakamiya, M.; Vaishnav, S.; Geske, R.; Montgomery, C., Jr.; Jones, P.; Bradley, A.; Caskey, C.T. Hyperuricemia and urate nephropathy in urate oxidase-deficient mice. Proc. Natl. Acad. Sci. USA 1994, 91, 742-746. [CrossRef] [PubMed]

142. Nakagawa, T.; Mazzali, M.; Kang, D.H.; Sanchez-Lozada, L.G.; Herrera-Acosta, J.; Johnson, R.J. Uric acid-A uremic toxin? Blood Purif. 2006, 24, 67-70. [CrossRef] [PubMed]

143. Ramirez-Sandoval, J.C.; Sanchez-Lozada, L.G.; Madero, M. Uric acid, vascular stiffness, and chronic kidney disease: Is there a link? Blood Purif. 2017, 43, 189-195. [CrossRef] [PubMed]

144. Tsai, C.W.; Lin, S.Y.; Kuo, C.C.; Huang, C.C. Serum uric acid and progression of kidney disease: A longitudinal analysis and mini-review. PLoS ONE 2017, 12, e0170393. [CrossRef] [PubMed]

145. Mehta, T.; Nuccio, E.; McFann, K.; Madero, M.; Sarnak, M.J.; Jalal, D. Association of uric acid with vascular stiffness in the framingham heart study. Am. J. Hypertens. 2015, 28, 877-883. [CrossRef] [PubMed]

146. Odden, M.C.; Amadu, A.R.; Smit, E.; Lo, L.; Peralta, C.A. Uric acid levels, kidney function, and cardiovascular mortality in us adults: National health and nutrition examination survey (nhanes) 1988-1994 and 1999-2002. Am. J. Kidney Dis. 2014, 64, 550-557. [CrossRef] [PubMed]

147. Kleber, M.E.; Delgado, G.; Grammer, T.B.; Silbernagel, G.; Huang, J.; Kramer, B.K.; Ritz, E.; Marz, W. Uric acid and cardiovascular events: A mendelian randomization study. J. Am. Soc. Nephrol. JASN 2015, 26, 2831-2838. [CrossRef] [PubMed]

148. Xia, X.; Luo, Q.; Li, B.; Lin, Z.; Yu, X.; Huang, F. Serum uric acid and mortality in chronic kidney disease: A systematic review and meta-analysis. Metab. Clin. Exp. 2016, 65, 1326-1341. [CrossRef] [PubMed]

149. Chen, Y.; Ding, X.; Teng, J.; Zou, J.; Zhong, Y.; Fang, Y.; Liu, Z.; Xu, S.; Wang, Y.; Shen, B. Serum uric acid is inversely related to acute ischemic stroke morbidity in hemodialysis patients. Am. J. Nephrol. 2011, 33, 97-104. [CrossRef] [PubMed]

150. Afsar, B.; Elsurer, R.; Covic, A.; Johnson, R.J.; Kanbay, M. Relationship between uric acid and subtle cognitive dysfunction in chronic kidney disease. Am. J. Nephrol. 2011, 34, 49-54. [CrossRef] [PubMed]

151. Hsu, W.L.; Li, S.Y.; Liu, J.S.; Huang, P.H.; Lin, S.J.; Hsu, C.C.; Lin, Y.P.; Tarng, D.C. High uric acid ameliorates indoxyl sulfate-induced endothelial dysfunction and is associated with lower mortality among hemodialysis patients. Toxins 2017, 9, 20. [CrossRef] [PubMed]

152. Park, C.; Obi, Y.; Streja, E.; Rhee, C.M.; Catabay, C.J.; Vaziri, N.D.; Kovesdy, C.P.; Kalantar-Zadeh, K. Serum uric acid, protein intake and mortality in hemodialysis patients. Nephrol. Dial. Transplant. 2017, 32, 1750-1757. [CrossRef] [PubMed]

153. Ng, K.P.; Stringer, S.J.; Jesky, M.D.; Yadav, P.; Athwal, R.; Dutton, M.; Ferro, C.J.; Cockwell, P. Allopurinol is an independent determinant of improved arterial stiffness in chronic kidney disease: A cross-sectional study. PLoS ONE 2014, 9, e91961. [CrossRef] [PubMed]

154. Tsuruta, Y.; Nitta, K.; Akizawa, T.; Fukuhara, S.; Saito, A.; Karaboyas, A.; Li, Y.; Port, F.K.; Robinson, B.M.; Pisoni, R.L.; et al. Association between allopurinol and mortality among japanese hemodialysis patients: Results from the dopps. Int. Urol. Nephrol. 2014, 46, 1833-1841. [CrossRef] [PubMed]

155. Jalal, D.I.; Decker, E.; Perrenoud, L.; Nowak, K.L.; Bispham, N.; Mehta, T.; Smits, G.; You, Z.; Seals, D.; Chonchol, M.; et al. Vascular function and uric acid-lowering in stage $3 \mathrm{ckd}$. J. Am. Soc. Nephrol. JASN 2017, 28, 943-952. [CrossRef] [PubMed]

156. Borgi, L.; McMullan, C.; Wohlhueter, A.; Curhan, G.C.; Fisher, N.D.; Forman, J.P. Effect of uric acid-lowering agents on endothelial function: A randomized, double-blind, placebo-controlled trial. Hypertension 2017, 69, 243-248. [CrossRef] [PubMed]

157. Feig, D.I.; Soletsky, B.; Johnson, R.J. Effect of allopurinol on blood pressure of adolescents with newly diagnosed essential hypertension: A randomized trial. JAMA 2008, 300, 924-932. [CrossRef] [PubMed]

158. Goicoechea, M.; Garcia de Vinuesa, S.; Verdalles, U.; Verde, E.; Macias, N.; Santos, A.; Perez de Jose, A.; Cedeno, S.; Linares, T.; Luno, J. Allopurinol and progression of ckd and cardiovascular events: Long-term follow-up of a randomized clinical trial. Am. J. Kidney Dis. 2015, 65, 543-549. [CrossRef] [PubMed]

159. Hsu, C.H.; Patel, S.R.; Young, E.W.; Vanholder, R. The biological action of calcitriol in renal failure. Kidney Int. 1994, 46, 605-612. [CrossRef] [PubMed]

160. Schepers, E.; Glorieux, G.; Vanholder, R. The gut: The forgotten organ in uremia? Blood Purif. 2010, 29, 130-136. [CrossRef] [PubMed] 
161. Schulman, G.; Berl, T.; Beck, G.J.; Remuzzi, G.; Ritz, E.; Arita, K.; Kato, A.; Shimizu, M. Randomized placebo-controlled eppic trials of ast-120 in ckd. J. Am. Soc. Nephrol. JASN 2015, 26, 1732-1746. [CrossRef] [PubMed]

162. Cha, R.H.; Kang, S.W.; Park, C.W.; Cha, D.R.; Na, K.Y.; Kim, S.G.; Yoon, S.A.; Han, S.Y.; Chang, J.H.; Park, S.K.; et al. A randomized, controlled trial of oral intestinal sorbent ast-120 on renal function deterioration in patients with advanced renal dysfunction. Clin. J. Am. Soc. Nephrol. CJASN 2016, 11, 559-567. [CrossRef] [PubMed]

163. Jourde-Chiche, N.; Dou, L.; Cerini, C.; Dignat-George, F.; Vanholder, R.; Brunet, P. Protein-bound toxins-update 2009. Semin. Dial. 2009, 22, 334-339. [CrossRef] [PubMed]

164. Gryp, T.; Vanholder, R.; Vaneechoutte, M.; Glorieux, G. P-cresyl sulfate. Toxins 2017, 9, 52. [CrossRef] [PubMed]

165. Leong, S.C.; Sirich, T.L. Indoxyl sulfate-review of toxicity and therapeutic strategies. Toxins 2016, 8, 358. [CrossRef] [PubMed]

166. Stinghen, A.E.; Massy, Z.A.; Vlassara, H.; Striker, G.E.; Boullier, A. Uremic toxicity of advanced glycation end products in ckd. J. Am. Soc. Nephrol. JASN 2016, 27, 354-370. [CrossRef] [PubMed]

167. Brownlee, M.; Cerami, A.; Vlassara, H. Advanced glycosylation end products in tissue and the biochemical basis of diabetic complications. N. Engl. J. Med. 1988, 318, 1315-1321. [PubMed]

168. Miyata, T.; van Ypersele de Strihou, C.; Kurokawa, K.; Baynes, J.W. Alterations in nonenzymatic biochemistry in uremia: Origin and significance of "carbonyl stress" in long-term uremic complications. Kidney Int. 1999, 55, 389-399. [CrossRef] [PubMed]

169. Papanastasiou, P.; Grass, L.; Rodela, H.; Patrikarea, A.; Oreopoulos, D.; Diamandis, E.P. Immunological quantification of advanced glycosylation end-products in the serum of patients on hemodialysis or capd. Kidney Int. 1994, 46, 216-222. [CrossRef] [PubMed]

170. Liu, J.; Huang, K.; Cai, G.Y.; Chen, X.M.; Yang, J.R.; Lin, L.R.; Yang, J.; Huo, B.G.; Zhan, J.; He, Y.N. Receptor for advanced glycation end-products promotes premature senescence of proximal tubular epithelial cells via activation of endoplasmic reticulum stress-dependent p21 signaling. Cell Signal. 2014, 26, 110-121. [CrossRef] [PubMed]

171. Kislinger, T.; Tanji, N.; Wendt, T.; Qu, W.; Lu, Y.; Ferran, L.J., Jr.; Taguchi, A.; Olson, K.; Bucciarelli, L.; Goova, M.; et al. Receptor for advanced glycation end products mediates inflammation and enhanced expression of tissue factor in vasculature of diabetic apolipoprotein e-null mice. Arterioscler. Thromb. Vasc. Biol. 2001, 21, 905-910. [CrossRef] [PubMed]

172. Ramasamy, R.; Yan, S.F.; Schmidt, A.M. Advanced glycation endproducts: From precursors to rage: Round and round we go. Amino Acids 2012, 42, 1151-1161. [CrossRef] [PubMed]

173. Abel, M.; Ritthaler, U.; Zhang, Y.; Deng, Y.; Schmidt, A.M.; Greten, J.; Sernau, T.; Wahl, P.; Andrassy, K.; Ritz, E.; et al. Expression of receptors for advanced glycosylated end-products in renal disease. Nephrol. Dial. Transplant. 1995, 10, 1662-1667. [PubMed]

174. Rebholz, C.M.; Astor, B.C.; Grams, M.E.; Halushka, M.K.; Lazo, M.; Hoogeveen, R.C.; Ballantyne, C.M.; Coresh, J.; Selvin, E. Association of plasma levels of soluble receptor for advanced glycation end products and risk of kidney disease: The atherosclerosis risk in communities study. Nephrol. Dial. Transplant. 2015, 30, 77-83. [CrossRef] [PubMed]

175. Yan, S.D.; Schmidt, A.M.; Anderson, G.M.; Zhang, J.; Brett, J.; Zou, Y.S.; Pinsky, D.; Stern, D. Enhanced cellular oxidant stress by the interaction of advanced glycation end products with their receptors/binding proteins. J. Biol. Chem. 1994, 269, 9889-9897. [PubMed]

176. Shi, X.Y.; Hou, F.F.; Niu, H.X.; Wang, G.B.; Xie, D.; Guo, Z.J.; Zhou, Z.M.; Yang, F.; Tian, J.W.; Zhang, X. Advanced oxidation protein products promote inflammation in diabetic kidney through activation of renal nicotinamide adenine dinucleotide phosphate oxidase. Endocrinology 2008, 149, 1829-1839. [CrossRef] [PubMed]

177. Imani, F.; Horii, Y.; Suthanthiran, M.; Skolnik, E.Y.; Makita, Z.; Sharma, V.; Sehajpal, P.; Vlassara, H. Advanced glycosylation endproduct-specific receptors on human and rat t-lymphocytes mediate synthesis of interferon gamma: Role in tissue remodeling. J. Exp. Med. 1993, 178, 2165-2172. [CrossRef] [PubMed]

178. Rashid, G.; Benchetrit, S.; Fishman, D.; Bernheim, J. Effect of advanced glycation end-products on gene expression and synthesis of tnf-alpha and endothelial nitric oxide synthase by endothelial cells. Kidney Int. 2004, 66, 1099-1106. [CrossRef] [PubMed] 
179. Bucala, R.; Tracey, K.J.; Cerami, A. Advanced glycosylation products quench nitric oxide and mediate defective endothelium-dependent vasodilatation in experimental diabetes. J. Clin. Investig. 1991, 87, 432-438. [CrossRef] [PubMed]

180. Schmidt, A.M.; Hori, O.; Chen, J.X.; Li, J.F.; Crandall, J.; Zhang, J.; Cao, R.; Yan, S.D.; Brett, J.; Stern, D. Advanced glycation endproducts interacting with their endothelial receptor induce expression of vascular cell adhesion molecule-1 (vcam-1) in cultured human endothelial cells and in mice. A potential mechanism for the accelerated vasculopathy of diabetes. J. Clin. Investig. 1995, 96, 1395-1403. [CrossRef] [PubMed]

181. Enomoto, M.; Adachi, H.; Yamagishi, S.; Takeuchi, M.; Furuki, K.; Hino, A.; Hiratsuka, A.; Takajo, Y.; Imaizumi, T. Positive association of serum levels of advanced glycation end products with thrombogenic markers in humans. Metab. Clin. Exp. 2006, 55, 912-917. [CrossRef] [PubMed]

182. Zhou, G.; Li, C.; Cai, L. Advanced glycation end-products induce connective tissue growth factor-mediated renal fibrosis predominantly through transforming growth factor beta-independent pathway. Am. J. Pathol. 2004, 165, 2033-2043. [CrossRef]

183. Rubin, M.R.; Paschalis, E.P.; Poundarik, A.; Sroga, G.E.; McMahon, D.J.; Gamsjaeger, S.; Klaushofer, K.; Vashishth, D. Advanced glycation endproducts and bone material properties in type 1 diabetic mice. PLOS ONE 2016, 11, e0154700.

184. Zimmerman, G.A.; Meistrell, M., 3rd; Bloom, O.; Cockroft, K.M.; Bianchi, M.; Risucci, D.; Broome, J.; Farmer, P.; Cerami, A.; Vlassara, H.; et al. Neurotoxicity of advanced glycation endproducts during focal stroke and neuroprotective effects of aminoguanidine. Proc. Natl. Acad. Sci. USA 1995, 92, 3744-3748. [CrossRef] [PubMed]

185. Taki, K.; Takayama, F.; Tsuruta, Y.; Niwa, T. Oxidative stress, advanced glycation end product, and coronary artery calcification in hemodialysis patients. Kidney Int. 2006, 70, 218-224. [CrossRef] [PubMed]

186. Rigalleau, V.; Cougnard-Gregoire, A.; Nov, S.; Gonzalez, C.; Maury, E.; Lorrain, S.; Gin, H.; Barberger-Gateau, P. Association of advanced glycation end products and chronic kidney disease with macroangiopathy in type 2 diabetes. J. Diabetes Complicat. 2015, 29, 270-274. [CrossRef] [PubMed]

187. Grossin, N.; Auger, F.; Niquet-Leridon, C.; Durieux, N.; Montaigne, D.; Schmidt, A.M.; Susen, S.; Jacolot, P.; Beuscart, J.B.; Tessier, F.J.; et al. Dietary cml-enriched protein induces functional arterial aging in a rage-dependent manner in mice. Mol. Nutr. Food Res. 2015, 59, 927-938. [CrossRef] [PubMed]

188. Schwedler, S.B.; Metzger, T.; Schinzel, R.; Wanner, C. Advanced glycation end products and mortality in hemodialysis patients. Kidney Int. 2002, 62, 301-310. [CrossRef] [PubMed]

189. Busch, M.; Franke, S.; Muller, A.; Wolf, M.; Gerth, J.; Ott, U.; Niwa, T.; Stein, G. Potential cardiovascular risk factors in chronic kidney disease: Ages, total homocysteine and metabolites, and the c-reactive protein. Kidney Int. 2004, 66, 338-347. [CrossRef] [PubMed]

190. Moriya, S.; Yamazaki, M.; Murakami, H.; Maruyama, K.; Uchiyama, S. Two soluble isoforms of receptors for advanced glycation end products (rage) in carotid atherosclerosis: The difference of soluble and endogenous secretory rage. J. Stroke Cerebrovasc. Dis. 2014, 23, 2540-2546. [CrossRef] [PubMed]

191. Galli, F.; Benedetti, S.; Floridi, A.; Canestrari, F.; Piroddi, M.; Buoncristiani, E.; Buoncristiani, U. Glycoxidation and inflammatory markers in patients on treatment with pmma-based protein-leaking dialyzers. Kidney Int. 2005, 67, 750-759. [CrossRef] [PubMed]

192. Fishbane, S.; Bucala, R.; Pereira, B.J.; Founds, H.; Vlassara, H. Reduction of plasma apolipoprotein-b by effective removal of circulating glycation derivatives in uremia. Kidney Int. 1997, 52, 1645-1650. [CrossRef] [PubMed]

193. Makita, Z.; Bucala, R.; Rayfield, E.J.; Friedman, E.A.; Kaufman, A.M.; Korbet, S.M.; Barth, R.H.; Winston, J.A.; Fuh, H.; Manogue, K.R.; et al. Reactive glycosylation endproducts in diabetic uraemia and treatment of renal failure. Lancet 1994, 343, 1519-1522. [CrossRef]

194. Macias-Cervantes, M.H.; Rodriguez-Soto, J.M.; Uribarri, J.; Diaz-Cisneros, F.J.; Cai, W.; Garay-Sevilla, M.E. Effect of an advanced glycation end product-restricted diet and exercise on metabolic parameters in adult overweight men. Nutrition 2015, 31, 446-451. [CrossRef] [PubMed]

195. Xue, M.; Weickert, M.O.; Qureshi, S.; Kandala, N.B.; Anwar, A.; Waldron, M.; Shafie, A.; Messenger, D.; Fowler, M.; Jenkins, G.; et al. Improved glycemic control and vascular function in overweight and obese subjects by glyoxalase 1 inducer formulation. Diabetes 2016, 65, 2282-2294. [CrossRef] [PubMed]

196. Rabbani, N.; Xue, M.; Thornalley, P.J. Methylglyoxal-induced dicarbonyl stress in aging and disease: First steps towards glyoxalase 1-based treatments. Clin. Sci. 2016, 130, 1677-1696. [CrossRef] [PubMed] 
197. Witko-Sarsat, V.; Friedlander, M.; Capeillere-Blandin, C.; Nguyen-Khoa, T.; Nguyen, A.T.; Zingraff, J.; Jungers, P.; Descamps-Latscha, B. Advanced oxidation protein products as a novel marker of oxidative stress in uremia. Kidney Int. 1996, 49, 1304-1313. [CrossRef] [PubMed]

198. Witko-Sarsat, V.; Gausson, V.; Nguyen, A.T.; Touam, M.; Drueke, T.; Santangelo, F.; Descamps-Latscha, B. Aopp-induced activation of human neutrophil and monocyte oxidative metabolism: A potential target for n-acetylcysteine treatment in dialysis patients. Kidney Int. 2003, 64, 82-91. [CrossRef] [PubMed]

199. Servettaz, A.; Guilpain, P.; Goulvestre, C.; Chereau, C.; Hercend, C.; Nicco, C.; Guillevin, L.; Weill, B.; Mouthon, L.; Batteux, F. Radical oxygen species production induced by advanced oxidation protein products predicts clinical evolution and response to treatment in systemic sclerosis. Ann. Rheum. Dis. 2007, 66, 1202-1209. [CrossRef] [PubMed]

200. Witko-Sarsat, V.; Friedlander, M.; Nguyen Khoa, T.; Capeillere-Blandin, C.; Nguyen, A.T.; Canteloup, S.; Dayer, J.M.; Jungers, P.; Drueke, T.; Descamps-Latscha, B. Advanced oxidation protein products as novel mediators of inflammation and monocyte activation in chronic renal failure. J. Immunol. 1998, 161, 2524-2532. [PubMed]

201. Descamps-Latscha, B.; Witko-Sarsat, V.; Nguyen-Khoa, T.; Nguyen, A.T.; Gausson, V.; Mothu, N.; London, G.M.; Jungers, P. Advanced oxidation protein products as risk factors for atherosclerotic cardiovascular events in nondiabetic predialysis patients. Am. J. Kidney Dis. 2005, 45, 39-47. [CrossRef] [PubMed]

202. Valli, A.; Suliman, M.E.; Meert, N.; Vanholder, R.; Lindholm, B.; Stenvinkel, P.; Watanabe, M.; Barany, P.; Alvestrand, A.; Anderstam, B. Overestimation of advanced oxidation protein products in uremic plasma due to presence of triglycerides and other endogenous factors. Clin. Chim. Acta Int. J. Clin. Chem. 2007, 379, 87-94. [CrossRef] [PubMed]

203. D'Agati, V.; Schmidt, A.M. Rage and the pathogenesis of chronic kidney disease. Nat. Rev. Nephrol. 2010, 6, 352-360. [CrossRef] [PubMed]

204. Garibaldi, S.; Barisione, C.; Marengo, B.; Ameri, P.; Brunelli, C.; Balbi, M.; Ghigliotti, G. Advanced oxidation protein products-modified albumin induces differentiation of raw264.7 macrophages into dendritic-like cells which is modulated by cell surface thiols. Toxins 2017, 9, 27. [CrossRef] [PubMed]

205. Depner, T.A. Suppression of tubular anion transport by an inhibitor of serum protein binding in uremia. Kidney Int. 1981, 20, 511-518. [CrossRef] [PubMed]

206. Lim, C.F.; Stockigt, J.R.; Curtis, A.J.; Wynne, K.N.; Barlow, J.W.; Topliss, D.J. A naturally occurring furan fatty acid enhances drug inhibition of thyroxine binding in serum. Metab. Clin. Exp. 1993, 42, 1468-1474. [CrossRef]

207. Tsutsumi, Y.; Maruyama, T.; Takadate, A.; Shimada, H.; Otagiri, M. Decreased bilirubin-binding capacity in uremic serum caused by an accumulation of furan dicarboxylic acid. Nephron 2000, 85, 60-64. [CrossRef] [PubMed]

208. Henderson, S.J.; Lindup, W.E. Renal organic acid transport: Uptake by rat kidney slices of a furan dicarboxylic acid which inhibits plasma protein binding of acidic ligands in uremia. Clin. Chim. Acta Int. J. Clin. Chem. 1992, 263, 54-60.

209. Deguchi, T.; Kusuhara, H.; Takadate, A.; Endou, H.; Otagiri, M.; Sugiyama, Y. Characterization of uremic toxin transport by organic anion transporters in the kidney. Kidney Int. 2004, 65, 162-174. [CrossRef] [PubMed]

210. Mabuchi, H.; Nakahashi, H. Inhibition of hepatic glutathione s-transferases by a major endogenous ligand substance present in uremic serum. Nephron 1988, 49, 281-283. [CrossRef] [PubMed]

211. Lim, C.F.; Bernard, B.F.; de Jong, M.; Docter, R.; Krenning, E.P.; Hennemann, G. A furan fatty acid and indoxyl sulfate are the putative inhibitors of thyroxine hepatocyte transport in uremia. J. Clin. Endocrinol. Metab. 1993, 76, 318-324. [PubMed]

212. Tsujimoto, M.; Kinoshita, Y.; Hirata, S.; Otagiri, M.; Ohtani, H.; Sawada, Y. Effects of uremic serum and uremic toxins on hepatic uptake of digoxin. Ther. Drug Monit. 2008, 30, 576-582. [CrossRef] [PubMed]

213. Niwa, T.; Aiuchi, T.; Nakaya, K.; Emoto, Y.; Miyazaki, T.; Maeda, K. Inhibition of mitochondrial respiration by furancarboxylic acid accumulated in uremic serum in its albumin-bound and non-dialyzable form. Clin. Nephrol. 1993, 39, 92-96. [PubMed] 
214. Costigan, M.G.; Callaghan, C.A.; Lindup, W.E. Hypothesis: Is accumulation of a furan dicarboxylic acid (3-carboxy-4- methyl-5-propyl-2-furanpropanoic acid) related to the neurological abnormalities in patients with renal failure? Nephron 1996, 73, 169-173. [PubMed]

215. Nagy, E.; Liu, Y.; Prentice, K.J.; Sloop, K.W.; Sanders, P.E.; Batchuluun, B.; Hammond, C.D.; Wheeler, M.B.; Durham, T.B. Synthesis and characterization of urofuranoic acids: In vivo metabolism of 2-(2-carboxyethyl)-4-methyl-5-propylfuran-3-carboxylic acid (cmpf) and effects on in vitro insulin secretion. J. Med. Chem. 2017, 60, 1860-1875. [CrossRef] [PubMed]

216. Prentice, K.J.; Luu, L.; Allister, E.M.; Liu, Y.; Jun, L.S.; Sloop, K.W.; Hardy, A.B.; Wei, L.; Jia, W.; Fantus, I.G.; et al. The furan fatty acid metabolite cmpf is elevated in diabetes and induces beta cell dysfunction. Cell Metab. 2014, 19, 653-666. [CrossRef] [PubMed]

217. Lankinen, M.A.; Hanhineva, K.; Kolehmainen, M.; Lehtonen, M.; Auriola, S.; Mykkanen, H.; Poutanen, K.; Schwab, U.; Uusitupa, M. Cmpf does not associate with impaired glucose metabolism in individuals with features of metabolic syndrome. PLoS ONE 2015, 10, e0124379. [CrossRef] [PubMed]

218. Niwa, T.; Yazawa, T.; Kodama, T.; Uehara, Y.; Maeda, K.; Yamada, K. Efficient removal of albumin-bound furancarboxylic acid, an inhibitor of erythropoiesis, by continuous ambulatory peritoneal dialysis. Nephron 1990, 56, 241-245. [CrossRef] [PubMed]

219. Costigan, M.G.; Lindup, W.E. Plasma clearance in the rat of a furan dicarboxylic acid which accumulates in uremia. Kidney Int. 1996, 49, 634-638. [CrossRef] [PubMed]

220. Vanholder, R.; De Smet, R.; Waterloos, M.A.; Van Landschoot, N.; Vogeleere, P.; Hoste, E.; Ringoir, S. Mechanisms of uremic inhibition of phagocyte reactive species production: Characterization of the role of p-cresol. Kidney Int. 1995, 47, 510-517. [CrossRef] [PubMed]

221. Vanholder, R.; Bammens, B.; de Loor, H.; Glorieux, G.; Meijers, B.; Schepers, E.; Massy, Z.; Evenepoel, P. Warning: The unfortunate end of p-cresol as a uraemic toxin. Nephrol. Dial. Transplant. 2011, 26, 1464-1467. [CrossRef] [PubMed]

222. De Loor, H.; Bammens, B.; Evenepoel, P.; De Preter, V.; Verbeke, K. Gas chromatographic-mass spectrometric analysis for measurement of p-cresol and its conjugated metabolites in uremic and normal serum. Clin. Chem. 2005, 51, 1535-1538. [CrossRef] [PubMed]

223. Martinez, A.W.; Recht, N.S.; Hostetter, T.H.; Meyer, T.W. Removal of p-cresol sulfate by hemodialysis. J. Am. Soc. Nephrol. JASN 2005, 16, 3430-3436. [CrossRef] [PubMed]

224. Koppe, L.; Alix, P.M.; Croze, M.L.; Chambert, S.; Vanholder, R.; Glorieux, G.; Fouque, D.; Soulage, C.O. $\mathrm{P}$-cresyl glucuronide is a major metabolite of $\mathrm{p}$-cresol in mouse: In contrast to p-cresyl sulphate, p-cresyl glucuronide fails to promote insulin resistance. Nephrol. Dial. Transplant. 2017, 32, 2000-2009. [CrossRef] [PubMed]

225. Liabeuf, S.; Glorieux, G.; Lenglet, A.; Diouf, M.; Schepers, E.; Desjardins, L.; Choukroun, G.; Vanholder, R.; Massy, Z.A.; European Uremic Toxin Work Group. Does p-cresylglucuronide have the same impact on mortality as other protein-bound uremic toxins? PLoS ONE 2013, 8, e67168. [CrossRef] [PubMed]

226. Vanholder, R.; Van Landschoot, N.; De Smet, R.; Schoots, A.; Ringoir, S. Drug protein binding in chronic renal failure: Evaluation of nine drugs. Kidney Int. 1988, 33, 996-1004. [CrossRef] [PubMed]

227. Satoh, M.; Hayashi, H.; Watanabe, M.; Ueda, K.; Yamato, H.; Yoshioka, T.; Motojima, M. Uremic toxins overload accelerates renal damage in a rat model of chronic renal failure. Nephron Exp. Nephrol. 2003, 95, e111-e118. [CrossRef] [PubMed]

228. Motojima, M.; Hosokawa, A.; Yamato, H.; Muraki, T.; Yoshioka, T. Uraemic toxins induce proximal tubular injury via organic anion transporter 1-mediated uptake. Br. J. Pharmacol. 2002, 135, 555-563. [CrossRef] [PubMed]

229. Edamatsu, T.; Fujieda, A.; Ezawa, A.; Itoh, Y. Classification of five uremic solutes according to their effects on renal tubular cells. Int. J. Nephrol. 2014, 2014, 512178. [CrossRef] [PubMed]

230. Zhao, Y.Y.; Lei, P.; Chen, D.Q.; Feng, Y.L.; Bai, X. Renal metabolic profiling of early renal injury and renoprotective effects of poria cocos epidermis using uplc q-tof/hsms/mse. J. Pharm. Biom. Anal. 2013, 81-82, 202-209. [CrossRef] [PubMed]

231. Van der Kloet, F.M.; Tempels, F.W.; Ismail, N.; van der Heijden, R.; Kasper, P.T.; Rojas-Cherto, M.; van Doorn, R.; Spijksma, G.; Koek, M.; van der Greef, J.; et al. Discovery of early-stage biomarkers for diabetic kidney disease using ms-based metabolomics (finndiane study). Metabolomics 2012, 8, 109-119. [CrossRef] [PubMed] 
232. Psihogios, N.G.; Kalaitzidis, R.G.; Dimou, S.; Seferiadis, K.I.; Siamopoulos, K.C.; Bairaktari, E.T. Evaluation of tubulointerstitial lesions' severity in patients with glomerulonephritides: An nmr-based metabonomic study. J. Proteome Res. 2007, 6, 3760-3770. [CrossRef] [PubMed]

233. Spustova, V.; Cernay, P.; Golier, I. Inhibition of glucose utilization in uremia by hippurate: Liquid chromatographic isolation and mass spectrometric and nuclear magnetic resonance spectroscopic identification. J. Chromatogr. 1989, 490, 186-192. [CrossRef]

234. Jankowski, J.; Tepel, M.; Stephan, N.; van der Giet, M.; Breden, V.; Zidek, W.; Schluter, H. Characterization of p-hydroxy-hippuric acid as an inhibitor of $\mathrm{ca}^{2+}$-atpase in end-stage renal failure. Kidney Int. Suppl. 2001, 78, S84-S88. [CrossRef] [PubMed]

235. Cohen, G.; Raupachova, J.; Wimmer, T.; Deicher, R.; Horl, W.H. The uraemic retention solute para-hydroxy-hippuric acid attenuates apoptosis of polymorphonuclear leukocytes from healthy subjects but not from haemodialysis patients. Nephrol. Dial. Transplant. 2008, 23, 2512-2519. [CrossRef] [PubMed]

236. Bostom, A.G.; Shemin, D.; Lapane, K.L.; Miller, J.W.; Sutherland, P.; Nadeau, M.; Seyoum, E.; Hartman, W.; Prior, R.; Wilson, P.W.; et al. Hyperhomocysteinemia and traditional cardiovascular disease risk factors in end-stage renal disease patients on dialysis: A case-control study. Atherosclerosis 1995, 114, 93-103. [CrossRef]

237. Perna, A.F.; Ingrosso, D.; De Santo, N.G.; Galletti, P.; Zappia, V. Mechanism of erythrocyte accumulation of methylation inhibitor s-adenosylhomocysteine in uremia. Kidney Int. 1995, 47, 247-253. [CrossRef] [PubMed]

238. Ingrosso, D.; Cimmino, A.; Perna, A.F.; Masella, L.; De Santo, N.G.; De Bonis, M.L.; Vacca, M.; D’Esposito, M.; D'Urso, M.; Galletti, P.; et al. Folate treatment and unbalanced methylation and changes of allelic expression induced by hyperhomocysteinaemia in patients with uraemia. Lancet 2003, 361, 1693-1699. [CrossRef]

239. Tsai, J.C.; Perrella, M.A.; Yoshizumi, M.; Hsieh, C.M.; Haber, E.; Schlegel, R.; Lee, M.E. Promotion of vascular smooth muscle cell growth by homocysteine: A link to atherosclerosis. Proc. Natl. Acad. Sci. USA 1994, 91, 6369-6373. [CrossRef] [PubMed]

240. Matthias, D.; Becker, C.H.; Riezler, R.; Kindling, P.H. Homocysteine induced arteriosclerosis-like alterations of the aorta in normotensive and hypertensive rats following application of high doses of methionine. Atherosclerosis 1996, 122, 201-216. [CrossRef]

241. Harpel, P.C.; Zhang, X.; Borth, W. Homocysteine and hemostasis: Pathogenic mechanisms predisposing to thrombosis. J. Nutr. 1996, 126, 1285S-1289S. [PubMed]

242. Perna, A.F.; Luciano, M.G.; Ingrosso, D.; Pulzella, P.; Sepe, I.; Lanza, D.; Violetti, E.; Capasso, R.; Lombardi, C.; De Santo, N.G. Hydrogen sulphide-generating pathways in haemodialysis patients: A study on relevant metabolites and transcriptional regulation of genes encoding for key enzymes. Nephrol. Dial. Transplant. 2009, 24, 3756-3763. [CrossRef] [PubMed]

243. Fodinger, M.; Mannhalter, C.; Wolfl, G.; Pabinger, I.; Muller, E.; Schmid, R.; Horl, W.H.; Sunder-Plassmann, G. Mutation $(677 \mathrm{c}$ to $\mathrm{t}$ ) in the methylenetetrahydrofolate reductase gene aggravates hyperhomocysteinemia in hemodialysis patients. Kidney Int. 1997, 52, 517-523. [CrossRef] [PubMed]

244. Robinson, K.; Arheart, K.; Refsum, H.; Brattstrom, L.; Boers, G.; Ueland, P.; Rubba, P.; Palma-Reis, R.; Meleady, R.; Daly, L.; et al. Low circulating folate and vitamin b6 concentrations: Risk factors for stroke, peripheral vascular disease, and coronary artery disease. European comac group. Circulation 1998, 97, 437-443. [CrossRef] [PubMed]

245. Ubbink, J.B.; Vermaak, W.J.; van der Merwe, A.; Becker, P.J. Vitamin b-12, vitamin b-6, and folate nutritional status in men with hyperhomocysteinemia. Am. J. Clin. Nutr. 1993, 57, 47-53. [CrossRef] [PubMed]

246. Bostom, A.G.; Shemin, D.; Lapane, K.L.; Nadeau, M.R.; Sutherland, P.; Chan, J.; Rozen, R.; Yoburn, D.; Jacques, P.F.; Selhub, J.; et al. Folate status is the major determinant of fasting total plasma homocysteine levels in maintenance dialysis patients. Atherosclerosis 1996, 123, 193-202. [CrossRef]

247. Kalantar-Zadeh, K.; Block, G.; Humphreys, M.H.; McAllister, C.J.; Kopple, J.D. A low, rather than a high, total plasma homocysteine is an indicator of poor outcome in hemodialysis patients. J. Am. Soc. Nephrol. JASN 2004, 15, 442-453. [CrossRef] [PubMed]

248. Ducloux, D.; Klein, A.; Kazory, A.; Devillard, N.; Chalopin, J.M. Impact of malnutrition-inflammation on the association between homocysteine and mortality. Kidney Int. 2006, 69, 331-335. [CrossRef] [PubMed]

249. Menon, V.; Sarnak, M.J.; Greene, T.; Wang, X.; Pereira, A.A.; Beck, G.J.; Kusek, J.W.; Selhub, J.; Collins, A.J.; Levey, A.S.; et al. Relationship between homocysteine and mortality in chronic kidney disease. Circulation 2006, 113, 1572-1577. [CrossRef] [PubMed] 
250. Jamison, R.L.; Hartigan, P.; Kaufman, J.S.; Goldfarb, D.S.; Warren, S.R.; Guarino, P.D.; Gaziano, J.M.; Veterans Affairs Site Investigators. Effect of homocysteine lowering on mortality and vascular disease in advanced chronic kidney disease and end-stage renal disease: A randomized controlled trial. JAMA 2007, 298, 1163-1170. [CrossRef] [PubMed]

251. Mann, J.F.; Sheridan, P.; McQueen, M.J.; Held, C.; Arnold, J.M.; Fodor, G.; Yusuf, S.; Lonn, E.M.; HOPE-2 Investigators. Homocysteine lowering with folic acid and $\mathrm{b}$ vitamins in people with chronic kidney disease-results of the renal hope-2 study. Nephrol. Dial. Transplant. 2008, 23, 645-653. [CrossRef] [PubMed]

252. House, A.A.; Eliasziw, M.; Cattran, D.C.; Churchill, D.N.; Oliver, M.J.; Fine, A.; Dresser, G.K.; Spence, J.D. Effect of b-vitamin therapy on progression of diabetic nephropathy: A randomized controlled trial. JAMA 2010, 303, 1603-1609. [CrossRef] [PubMed]

253. Heinz, J.; Kropf, S.; Domrose, U.; Westphal, S.; Borucki, K.; Luley, C.; Neumann, K.H.; Dierkes, J. B vitamins and the risk of total mortality and cardiovascular disease in end-stage renal disease: Results of a randomized controlled trial. Circulation 2010, 121, 1432-1438. [CrossRef] [PubMed]

254. Huo, Y.; Li, J.; Qin, X.; Huang, Y.; Wang, X.; Gottesman, R.F.; Tang, G.; Wang, B.; Chen, D.; He, M.; et al. Efficacy of folic acid therapy in primary prevention of stroke among adults with hypertension in china: The csppt randomized clinical trial. JAMA 2015, 313, 1325-1335. [CrossRef] [PubMed]

255. Xu, X.; Qin, X.; Li, Y.; Sun, D.; Wang, J.; Liang, M.; Wang, B.; Huo, Y. Efficacy of folic acid therapy on the progression of chronic kidney disease. JAMA Intern. Med. 2016, 176, 1443-1450. [CrossRef] [PubMed]

256. Heinz, J.; Kropf, S.; Luley, C.; Dierkes, J. Homocysteine as a risk factor for cardiovascular disease in patients treated by dialysis: A meta-analysis. Am. J. Kidney Dis. 2009, 54, 478-489. [CrossRef] [PubMed]

257. Qin, X.; Huo, Y.; Langman, C.B.; Hou, F.; Chen, Y.; Matossian, D.; Xu, X.; Wang, X. Folic acid therapy and cardiovascular disease in esrd or advanced chronic kidney disease: A meta-analysis. Clin. J. Am. Soc. Nephrol. CJASN 2011, 6, 482-488. [CrossRef] [PubMed]

258. De Vriese, A.S.; Langlois, M.; Bernard, D.; Geerolf, I.; Stevens, L.; Boelaert, J.R.; Schurgers, M.; Matthys, E. Effect of dialyser membrane pore size on plasma homocysteine levels in haemodialysis patients. Nephrol. Dial. Transplant. 2003, 18, 2596-2600. [CrossRef] [PubMed]

259. Sirich, T.; Meyer, T.W. Indoxyl sulfate: Long suspected but not yet proven guilty. Clin. J. Am. Soc. Nephrol. CJASN 2011, 6, 3-4. [CrossRef] [PubMed]

260. Barreto, F.C.; Barreto, D.V.; Stinghen, A.E.M.; Massy, Z.A. Comment on indoxyl sulfate-review of toxicity and therapeutic strategies. Toxins 2016, 8, 358, Erratum in 2017, 9, 142.

261. Wu, C.C.; Hung, S.C.; Kuo, K.L.; Tarng, D.C. Impact of indoxyl sulfate on progenitor cell-related neovascularization of peripheral arterial disease and post-angioplasty thrombosis of dialysis vascular access. Toxins 2017, 9, 25. [CrossRef] [PubMed]

262. Karbowska, M.; Kaminski, T.W.; Marcinczyk, N.; Misztal, T.; Rusak, T.; Smyk, L.; Pawlak, D. The uremic toxin indoxyl sulfate accelerates thrombotic response after vascular injury in animal models. Toxins 2017, 9, 229. [CrossRef] [PubMed]

263. Dou, L.; Sallee, M.; Cerini, C.; Poitevin, S.; Gondouin, B.; Jourde-Chiche, N.; Fallague, K.; Brunet, P.; Calaf, R.; Dussol, B.; et al. The cardiovascular effect of the uremic solute indole-3 acetic acid. J. Am. Soc. Nephrol. JASN 2015, 26, 876-887. [CrossRef] [PubMed]

264. Wu, D.; Nishimura, N.; Kuo, V.; Fiehn, O.; Shahbaz, S.; Van Winkle, L.; Matsumura, F.; Vogel, C.F. Activation of aryl hydrocarbon receptor induces vascular inflammation and promotes atherosclerosis in apolipoprotein e-/- mice. Arterioscler. Thromb. Vasc. Biol. 2011, 31, 1260-1267. [CrossRef] [PubMed]

265. Gondouin, B.; Cerini, C.; Dou, L.; Sallee, M.; Duval-Sabatier, A.; Pletinck, A.; Calaf, R.; Lacroix, R.; Jourde-Chiche, N.; Poitevin, S.; et al. Indolic uremic solutes increase tissue factor production in endothelial cells by the aryl hydrocarbon receptor pathway. Kidney Int. 2013, 84, 733-744. [CrossRef] [PubMed]

266. Sallee, M.; Dou, L.; Cerini, C.; Poitevin, S.; Brunet, P.; Burtey, S. The aryl hydrocarbon receptor-activating effect of uremic toxins from tryptophan metabolism: A new concept to understand cardiovascular complications of chronic kidney disease. Toxins 2014, 6, 934-949. [CrossRef] [PubMed]

267. Oliveira, D.L.; Pugine, S.M.; Ferreira, M.S.; Lins, P.G.; Costa, E.J.; de Melo, M.P. Influence of indole acetic acid on antioxidant levels and enzyme activities of glucose metabolism in rat liver. Cell Biochem. Funct. 2007, 25, 195-201. [CrossRef] [PubMed] 
268. Dalmazzo, L.F.; Santana-Lemos, B.A.; Jacomo, R.H.; Garcia, A.B.; Rego, E.M.; da Fonseca, L.M.; Falcao, R.P. Antibody-targeted horseradish peroxidase associated with indole-3-acetic acid induces apoptosis in vitro in hematological malignancies. Leuk. Res. 2011, 35, 657-662. [CrossRef] [PubMed]

269. Niwa, T.; Miyazaki, T.; Tsukushi, S.; Maeda, K.; Tsubakihara, Y.; Owada, A.; Shiigai, T. Accumulation of indoxyl-beta-d-glucuronide in uremic serum: Suppression of its production by oral sorbent and efficient removal by hemodialysis. Nephron 1996, 74, 72-78. [CrossRef] [PubMed]

270. Saito, K.; Fujigaki, S.; Heyes, M.P.; Shibata, K.; Takemura, M.; Fujii, H.; Wada, H.; Noma, A.; Seishima, M. Mechanism of increases in 1-kynurenine and quinolinic acid in renal insufficiency. Am. J. Physiol. Ren. Physiol. 2000, 279, F565-F572. [CrossRef] [PubMed]

271. Barth, M.C.; Ahluwalia, N.; Anderson, T.J.; Hardy, G.J.; Sinha, S.; Alvarez-Cardona, J.A.; Pruitt, I.E.; Rhee, E.P.; Colvin, R.A.; Gerszten, R.E. Kynurenic acid triggers firm arrest of leukocytes to vascular endothelium under flow conditions. J. Biol. Chem. 2009, 284, 19189-19195. [CrossRef] [PubMed]

272. Wang, J.; Simonavicius, N.; Wu, X.; Swaminath, G.; Reagan, J.; Tian, H.; Ling, L. Kynurenic acid as a ligand for orphan g protein-coupled receptor gpr35. J. Biol. Chem. 2006, 281, 22021-22028. [CrossRef] [PubMed]

273. Alexander, K.S.; Wu, H.Q.; Schwarcz, R.; Bruno, J.P. Acute elevations of brain kynurenic acid impair cognitive flexibility: Normalization by the alpha7 positive modulator galantamine. Psychopharmacology 2012, 220, 627-637. [CrossRef] [PubMed]

274. Sato, T.; Yamaguchi, H.; Kogawa, T.; Abe, T.; Mano, N. Organic anion transporting polypeptides $1 \mathrm{~b} 1$ and $1 \mathrm{~b} 3$ play an important role in uremic toxin handling and drug-uremic toxin interactions in the liver. J. Pharm. Pharm. Sci. 2014, 17, 475-484. [CrossRef] [PubMed]

275. Schuck, P.F.; Tonin, A.; da Costa Ferreira, G.; Viegas, C.M.; Latini, A.; Duval Wannmacher, C.M.; de Souza Wyse, A.T.; Dutra-Filho, C.S.; Wajner, M. Kynurenines impair energy metabolism in rat cerebral cortex. Cell. Mol. Neurobiol. 2007, 27, 147-160. [CrossRef] [PubMed]

276. Zuo, H.; Ueland, P.M.; Ulvik, A.; Eussen, S.J.; Vollset, S.E.; Nygard, O.; Midttun, O.; Theofylaktopoulou, D.; Meyer, K.; Tell, G.S. Plasma biomarkers of inflammation, the kynurenine pathway, and risks of all-cause, cancer, and cardiovascular disease mortality: The hordaland health study. Am. J. Epidemiol. 2016, 183, $249-258$. [CrossRef] [PubMed]

277. Pedersen, E.R.; Tuseth, N.; Eussen, S.J.; Ueland, P.M.; Strand, E.; Svingen, G.F.; Midttun, O.; Meyer, K.; Mellgren, G.; Ulvik, A.; et al. Associations of plasma kynurenines with risk of acute myocardial infarction in patients with stable angina pectoris. Arterioscler. Thromb. Vasc. Biol. 2015, 35, 455-462. [CrossRef] [PubMed]

278. Pawlak, K.; Domaniewski, T.; Mysliwiec, M.; Pawlak, D. The kynurenines are associated with oxidative stress, inflammation and the prevalence of cardiovascular disease in patients with end-stage renal disease. Atherosclerosis 2009, 204, 309-314. [CrossRef] [PubMed]

279. Pawlak, K.; Mysliwiec, M.; Pawlak, D. Hypercoagulability is independently associated with kynurenine pathway activation in dialysed uraemic patients. Thromb. Haemost. 2009, 102, 49-55. [CrossRef] [PubMed]

280. Saldanha, J.F.; Yi, D.; Stockler-Pinto, M.B.; Soula, H.A.; Chambert, S.; Fouque, D.; Mafra, D.; Soulage, C.O. Determination of the binding properties of the uremic toxin phenylacetic acid to human serum albumin. Biochimie 2016, 125, 53-58. [CrossRef] [PubMed]

281. Jankowski, J.; van der Giet, M.; Jankowski, V.; Schmidt, S.; Hemeier, M.; Mahn, B.; Giebing, G.; Tolle, M.; Luftmann, H.; Schluter, H.; et al. Increased plasma phenylacetic acid in patients with end-stage renal failure inhibits inos expression. J. Clin. Investig. 2003, 112, 256-264. [CrossRef] [PubMed]

282. Yano, S.; Yamaguchi, T.; Kanazawa, I.; Ogawa, N.; Hayashi, K.; Yamauchi, M.; Sugimoto, T. The uraemic toxin phenylacetic acid inhibits osteoblastic proliferation and differentiation: An implication for the pathogenesis of low turnover bone in chronic renal failure. Nephrol. Dial. Transplant. 2007, 22, 3160-3165. [CrossRef] [PubMed]

283. Schmidt, S.; Westhoff, T.H.; Krauser, P.; Zidek, W.; van der Giet, M. The uraemic toxin phenylacetic acid increases the formation of reactive oxygen species in vascular smooth muscle cells. Nephrol. Dial. Transplant. 2008, 23, 65-71. [CrossRef] [PubMed]

284. Cohen, G.; Raupachova, J.; Horl, W.H. The uraemic toxin phenylacetic acid contributes to inflammation by priming polymorphonuclear leucocytes. Nephrol. Dial. Transplant. 2013, 28, 421-429. [CrossRef] [PubMed]

285. Pawlak, D.; Koda, M.; Pawlak, S.; Wolczynski, S.; Buczko, W. Contribution of quinolinic acid in the development of anemia in renal insufficiency. Am. J. Physiol. Ren. Physiol. 2003, 284, F693-700. [CrossRef] [PubMed] 
286. Guillemin, G.J. Quinolinic acid, the inescapable neurotoxin. FEBS J. 2012, 279, 1356-1365. [CrossRef] [PubMed]

287. Grooteman, M.P.; van den Dorpel, M.A.; Bots, M.L.; Penne, E.L.; van der Weerd, N.C.; Mazairac, A.H.; den Hoedt, C.H.; van der Tweel, I.; Levesque, R.; Nube, M.J.; et al. Effect of online hemodiafiltration on all-cause mortality and cardiovascular outcomes. J. Am. Soc. Nephrol. JASN 2012, 23, 1087-1096. [CrossRef] [PubMed]

288. Ok, E.; Asci, G.; Toz, H.; Ok, E.S.; Kircelli, F.; Yilmaz, M.; Hur, E.; Demirci, M.S.; Demirci, C.; Duman, S.; et al. Mortality and cardiovascular events in online haemodiafiltration (ol-hdf) compared with high-flux dialysis: Results from the turkish ol-hdf study. Nephrol. Dial. Transplant. 2013, 28, 192-202. [CrossRef] [PubMed]

289. Morena, M.; Jaussent, A.; Chalabi, L.; Leray-Moragues, H.; Chenine, L.; Debure, A.; Thibaudin, D.; Azzouz, L.; Patrier, L.; Maurice, F.; et al. Treatment tolerance and patient-reported outcomes favor online hemodiafiltration compared to high-flux hemodialysis in the elderly. Kidney Int. 2017, 91, 1495-1509. [CrossRef] [PubMed]

290. Locatelli, F.; Karaboyas, A.; Pisoni, R.L.; Robinson, B.M.; Fort, J.; Vanholder, R.; Rayner, H.C.; Kleophas, W.; Jacobson, S.H.; Combe, C.; et al. Mortality risk in patients on hemodiafiltration versus hemodialysis: A 'real-world' comparison from the dopps. Nephrol. Dial. Transplant. 2017. [CrossRef] [PubMed]

291. Maduell, F.; Moreso, F.; Pons, M.; Ramos, R.; Mora-Macia, J.; Carreras, J.; Soler, J.; Torres, F.; Campistol, J.M.; Martinez-Castelao, A.; et al. High-efficiency postdilution online hemodiafiltration reduces all-cause mortality in hemodialysis patients. J. Am. Soc. Nephrol. JASN 2013, 24, 487-497. [CrossRef] [PubMed]

292. Mallamaci, F.; Zoccali, C.; Parlongo, S.; Cutrupi, S.; Tripepi, G.; Postorino, M. Plasma adrenomedullin during acute changes in intravascular volume in hemodialysis patients. Kidney Int. 1998, 54, 1697-1703. [CrossRef] [PubMed]

293. Temmesfeld-Wollbruck, B.; Brell, B.; zu Dohna, C.; Dorenberg, M.; Hocke, A.C.; Martens, H.; Klar, J.; Suttorp, N.; Hippenstiel, S. Adrenomedullin reduces intestinal epithelial permeability in vivo and in vitro. Am. J. Physiol. Gastrointest. Liver Physiol. 2009, 297, G43-G51. [CrossRef] [PubMed]

294. Temmesfeld-Wollbruck, B.; Hocke, A.C.; Suttorp, N.; Hippenstiel, S. Adrenomedullin and endothelial barrier function. Thromb. Haemost. 2007, 98, 944-951. [CrossRef] [PubMed]

295. Kapas, S.; Brown, D.W.; Farthing, P.M.; Hagi-Pavli, E. Adrenomedullin has mitogenic effects on human oral keratinocytes: Involvement of cyclic amp. FEBS Lett. 1997, 418, 287-290. [CrossRef]

296. Castillo-Rodriguez, E.; Pizarro-Sanchez, S.; Sanz, A.B.; Ramos, A.M.; Sanchez-Nino, M.D.; Martin-Cleary, C.; Fernandez-Fernandez, B.; Ortiz, A. Inflammatory cytokines as uremic toxins: “Ni son todos los que estan, ni estan todos los que son". Toxins 2017, 9, 114. [CrossRef] [PubMed]

297. Tello-Montoliu, A.; Patel, J.V.; Lip, G.Y. Angiogenin: A review of the pathophysiology and potential clinical applications. J. Thromb. Haemost. JTH 2006, 4, 1864-1874. [CrossRef] [PubMed]

298. Tschesche, H.; Kopp, C.; Horl, W.H.; Hempelmann, U. Inhibition of degranulation of polymorphonuclear leukocytes by angiogenin and its tryptic fragment. J. Biol. Chem. 1994, 269, 30274-30280. [PubMed]

299. Saxena, S.K.; Rybak, S.M.; Davey, R.T., Jr.; Youle, R.J.; Ackerman, E.J. Angiogenin is a cytotoxic, trna-specific ribonuclease in the rnase a superfamily. J. Biol. Chem. 1992, 267, 21982-21986. [PubMed]

300. Zoccali, C.; Mallamaci, F.; Benedetto, F.A.; Tripepi, G.; Parlongo, S.; Cataliotti, A.; Cutrupi, S.; Giacone, G.; Bellanuova, I.; Cottini, E.; et al. Cardiac natriuretic peptides are related to left ventricular mass and function and predict mortality in dialysis patients. J. Am. Soc. Nephrol. JASN 2001, 12, 1508-1515. [PubMed]

301. Smith, S.; Anderson, S.; Ballermann, B.J.; Brenner, B.M. Role of atrial natriuretic peptide in adaptation of sodium excretion with reduced renal mass. J. Clin. Investig. 1986, 77, 1395-1398. [CrossRef] [PubMed]

302. Drewett, J.G.; Ziegler, R.J.; Trachte, G.J. Neuromodulatory effects of atrial natriuretic peptides correlate with an inhibition of adenylate cyclase but not an activation of guanylate cyclase. J. Pharmacol. Exp. Ther. 1992, 260, 689-696. [PubMed]

303. Zhao, L.; Winter, R.J.; Krausz, T.; Hughes, J.M. Effects of continuous infusion of atrial natriuretic peptide on the pulmonary hypertension induced by chronic hypoxia in rats. Clin. Sci. 1991, 81, 379-385. [CrossRef] [PubMed]

304. Janssen, W.M.; de Jong, P.E.; van der Hem, G.K.; de Zeeuw, D. Effect of human atrial natriuretic peptide on blood pressure after sodium depletion in essential hypertension. Br. Med. J. 1986, 293, 351-353. [CrossRef] 
305. Uehlinger, D.E.; Weidmann, P.; Gnadinger, M.P.; Hasler, L.; Bachmann, C.; Shaw, S.; Hellmuller, B.; Lang, R.E. Increase in circulating insulin induced by atrial natriuretic peptide in normal humans. J. Cardiovasc. Pharmacol. 1986, 8, 1122-1129. [CrossRef] [PubMed]

306. Verspohl, E.J.; Bernemann, I.K. Atrial natriuretic peptide (anp)-induced inhibition of glucagon secretion: Mechanism of action in isolated rat pancreatic islets. Peptides 1996, 17, 1023-1029. [CrossRef]

307. Zhang, M.; Tao, Y.; Zhou, B.; Xie, H.; Wang, F.; Lei, L.; Huo, L.; Sun, Q.; Xia, G. Atrial natriuretic peptide inhibits the actions of fsh and forskolin in meiotic maturation of pig oocytes via different signalling pathways. J. Mol. Endocrinol. 2005, 34, 459-472. [CrossRef] [PubMed]

308. Desai, A.S.; Bibbins-Domingo, K.; Shlipak, M.G.; Wu, A.H.; Ali, S.; Whooley, M.A. Association between anaemia and n-terminal pro-b-type natriuretic peptide (nt-probnp): Findings from the heart and soul study. Eur. J. Heart Fail. 2007, 9, 886-891. [CrossRef] [PubMed]

309. Drueke, T.B.; Massy, Z.A. Beta2-microglobulin. Semin. Dial. 2009, 22, 378-380. [CrossRef] [PubMed]

310. Jadoul, M.; Garbar, C.; Noel, H.; Sennesael, J.; Vanholder, R.; Bernaert, P.; Rorive, G.; Hanique, G.; van Ypersele de Strihou, C. Histological prevalence of beta 2-microglobulin amyloidosis in hemodialysis: A prospective post-mortem study. Kidney Int. 1997, 51, 1928-1932. [CrossRef] [PubMed]

311. Jadoul, M.; Garbar, C.; Vanholder, R.; Sennesael, J.; Michel, C.; Robert, A.; Noel, H.; van Ypersele de Strihou, C. Prevalence of histological beta2-microglobulin amyloidosis in capd patients compared with hemodialysis patients. Kidney Int. 1998, 54, 956-959. [CrossRef] [PubMed]

312. Van Ypersele de Strihou, C.; Jadoul, M.; Malghem, J.; Maldague, B.; Jamart, J. Effect of dialysis membrane and patient's age on signs of dialysis-related amyloidosis. The working party on dialysis amyloidosis. Kidney Int. 1991, 39, 1012-1019. [CrossRef] [PubMed]

313. Schwalbe, S.; Holzhauer, M.; Schaeffer, J.; Galanski, M.; Koch, K.M.; Floege, J. Beta 2-microglobulin associated amyloidosis: A vanishing complication of long-term hemodialysis? Kidney Int. 1997, 52, 1077-1083. [CrossRef] [PubMed]

314. Niwa, T.; Katsuzaki, T.; Miyazaki, S.; Momoi, T.; Akiba, T.; Miyazaki, T.; Nokura, K.; Hayase, F.; Tatemichi, N.; Takei, Y. Amyloid beta 2-microglobulin is modified with imidazolone, a novel advanced glycation end product, in dialysis-related amyloidosis. Kidney Int. 1997, 51, 187-194. [CrossRef] [PubMed]

315. Niwa, T.; Sato, M.; Katsuzaki, T.; Tomoo, T.; Miyazaki, T.; Tatemichi, N.; Takei, Y.; Kondo, T. Amyloid beta 2-microglobulin is modified with $\mathrm{n}$ epsilon-(carboxymethyl)lysine in dialysis-related amyloidosis. Kidney Int. 1996, 50, 1303-1309. [CrossRef] [PubMed]

316. Miyata, T.; Inagi, R.; Iida, Y.; Sato, M.; Yamada, N.; Oda, O.; Maeda, K.; Seo, H. Involvement of beta 2-microglobulin modified with advanced glycation end products in the pathogenesis of hemodialysis-associated amyloidosis. Induction of human monocyte chemotaxis and macrophage secretion of tumor necrosis factor-alpha and interleukin-1. J. Clin. Investig. 1994, 93, 521-528. [CrossRef] [PubMed]

317. Hodkinson, J.P.; Radford, S.E.; Ashcroft, A.E. The role of conformational flexibility in beta2-microglobulin amyloid fibril formation at neutral ph. Rapid Commun. Mass Spectrom. RCM 2012, 26, 1783-1792. [CrossRef] [PubMed]

318. Kumar, S.; Sharma, P.; Arora, K.; Raje, M.; Guptasarma, P. Calcium binding to beta-2-microglobulin at physiological ph drives the occurrence of conformational changes which cause the protein to precipitate into amorphous forms that subsequently transform into amyloid aggregates. PLoS ONE 2014, 9, e95725. [CrossRef] [PubMed]

319. Porter, M.Y.; Routledge, K.E.; Radford, S.E.; Hewitt, E.W. Characterization of the response of primary cells relevant to dialysis-related amyloidosis to beta2-microglobulin monomer and fibrils. PLoS ONE 2011, 6, e27353. [CrossRef] [PubMed]

320. Liabeuf, S.; Lenglet, A.; Desjardins, L.; Neirynck, N.; Glorieux, G.; Lemke, H.D.; Vanholder, R.; Diouf, M.; Choukroun, G.; Massy, Z.A.; et al. Plasma beta-2 microglobulin is associated with cardiovascular disease in uremic patients. Kidney Int. 2012, 82, 1297-1303. [CrossRef] [PubMed]

321. Cheung, A.K.; Greene, T.; Leypoldt, J.K.; Yan, G.; Allon, M.; Delmez, J.; Levey, A.S.; Levin, N.W.; Rocco, M.V.; Schulman, G.; et al. Association between serum 2-microglobulin level and infectious mortality in hemodialysis patients. Clin. J. Am. Soc. Nephrol. CJASN 2008, 3, 69-77. [CrossRef] [PubMed]

322. Cheung, A.K.; Rocco, M.V.; Yan, G.; Leypoldt, J.K.; Levin, N.W.; Greene, T.; Agodoa, L.; Bailey, J.; Beck, G.J.; Clark, W.; et al. Serum beta-2 microglobulin levels predict mortality in dialysis patients: Results of the hemo study. J. Am. Soc. Nephrol. JASN 2006, 17, 546-555. [CrossRef] [PubMed] 
323. Kuragano, T.; Kida, A.; Furuta, M.; Nanami, M.; Otaki, Y.; Hasuike, Y.; Nonoguchi, H.; Nakanishi, T. The impact of beta2-microglobulin clearance on the risk factors of cardiovascular disease in hemodialysis patients. ASAIO J. 2010, 56, 326-332. [PubMed]

324. Raikou, V.D.; Tentolouris, N.; Kyriaki, D.; Evaggelatou, A.; Tzanatou, H. Beta2-microglobulin, pulse pressure and metabolic alterations in hemodialysis patients. Nephron. Clinical practice 2011, 117, c237-c245. [CrossRef] [PubMed]

325. Cheung, C.L.; Lam, K.S.; Cheung, B.M. Serum beta-2 microglobulin predicts mortality in people with diabetes. Eur.J. Endocrinol. 2013, 169, 1-7. [CrossRef] [PubMed]

326. Quesada, J.M.; Alonso, J.; Gonzalez, J.; Munoz, R.; Jans, I.; Martiu, A.; Bouillon, R. Serum beta-2 microglobulin is a marker of high bone remodelling in elderly women. Mech. Ageing Dev. 1998, 102, 293-298. [CrossRef]

327. Ripoll, E.; Revilla, M.; Hernandez, E.R.; Arribas, I.; Villa, L.F.; Rico, H. New evidence that serum beta(2)-microglobulin behaves as a biological marker of bone remodelling in women. Eur. J. Clin. Investig. 1996, 26, 681-685. [CrossRef]

328. Wilson, A.M.; Kimura, E.; Harada, R.K.; Nair, N.; Narasimhan, B.; Meng, X.Y.; Zhang, F.; Beck, K.R.; Olin, J.W.; Fung, E.T.; et al. Beta2-microglobulin as a biomarker in peripheral arterial disease: Proteomic profiling and clinical studies. Circulation 2007, 116, 1396-1403. [CrossRef] [PubMed]

329. Pavone, B.; Bucci, S.; Sirolli, V.; Merlini, G.; Del Boccio, P.; Di Rienzo, M.; Felaco, P.; Amoroso, L.; Sacchetta, P.; Di Ilio, C.; et al. Beta2-microglobulin causes abnormal phosphatidylserine exposure in human red blood cells. Mol. BioSyst. 2011, 7, 651-658. [CrossRef] [PubMed]

330. Menaa, C.; Esser, E.; Sprague, S.M. Beta2-microglobulin stimulates osteoclast formation. Kidney Int. 2008, 73, 1275-1281. [CrossRef] [PubMed]

331. Josson, S.; Nomura, T.; Lin, J.T.; Huang, W.C.; Wu, D.; Zhau, H.E.; Zayzafoon, M.; Weizmann, M.N.; Gururajan, M.; Chung, L.W. Beta2-microglobulin induces epithelial to mesenchymal transition and confers cancer lethality and bone metastasis in human cancer cells. Cancer Res. 2011, 71, 2600-2610. [CrossRef] [PubMed]

332. Giorgetti, S.; Raimondi, S.; Cassinelli, S.; Bucciantini, M.; Stefani, M.; Gregorini, G.; Albonico, G.; Moratti, R.; Montagna, G.; Stoppini, M.; et al. Beta2-microglobulin is potentially neurotoxic, but the blood brain barrier is likely to protect the brain from its toxicity. Nephrol. Dial. Transplant. 2009, 24, 1176-1181. [CrossRef] [PubMed]

333. Smith, L.K.; He, Y.; Park, J.S.; Bieri, G.; Snethlage, C.E.; Lin, K.; Gontier, G.; Wabl, R.; Plambeck, K.E.; Udeochu, J.; et al. Beta2-microglobulin is a systemic pro-aging factor that impairs cognitive function and neurogenesis. Nat. Med. 2015, 21, 932-937. [CrossRef] [PubMed]

334. Neirynck, N.; Glorieux, G.; Boelaert, J.; Schepers, E.; Liabeuf, S.; Dhondt, A.; Massy, Z.; Vanholder, R. Uremia-related oxidative stress in leukocytes is not triggered by beta2-microglobulin. J. Ren. Nutr. 2013, 23, 456-463. [CrossRef] [PubMed]

335. Neirynck, N.; Eloot, S.; Glorieux, G.; Barreto, D.V.; Barreto, F.C.; Liabeuf, S.; Lenglet, A.; Lemke, H.D.; Massy, Z.A.; Vanholder, R. Estimated glomerular filtration rate is a poor predictor of the concentration of middle molecular weight uremic solutes in chronic kidney disease. PLoS ONE 2012, 7, e44201. [CrossRef] [PubMed]

336. Ward, R.A.; Schmidt, B.; Hullin, J.; Hillebrand, G.F.; Samtleben, W. A comparison of on-line hemodiafiltration and high-flux hemodialysis: A prospective clinical study. J. Am. Soc. Nephrol. JASN 2000, 11, 2344-2350. [PubMed]

337. Locatelli, F.; Mastrangelo, F.; Redaelli, B.; Ronco, C.; Marcelli, D.; La Greca, G.; Orlandini, G. Effects of different membranes and dialysis technologies on patient treatment tolerance and nutritional parameters. The italian cooperative dialysis study group. Kidney Int. 1996, 50, 1293-1302. [CrossRef] [PubMed]

338. Locatelli, F.; Martin-Malo, A.; Hannedouche, T.; Loureiro, A.; Papadimitriou, M.; Wizemann, V.; Jacobson, S.H.; Czekalski, S.; Ronco, C.; Vanholder, R.; et al. Effect of membrane permeability on survival of hemodialysis patients. J. Am. Soc. Nephrol. JASN 2009, 20, 645-654. [CrossRef] [PubMed]

339. Maduell, F.; Navarro, V.; Cruz, M.C.; Torregrosa, E.; Garcia, D.; Simon, V.; Ferrero, J.A. Osteocalcin and myoglobin removal in on-line hemodiafiltration versus low- and high-flux hemodialysis. Am. J. Kidney Dis. 2002, 40, 582-589. [CrossRef] [PubMed] 
340. Meert, N.; Eloot, S.; Waterloos, M.A.; Van Landschoot, M.; Dhondt, A.; Glorieux, G.; Ledebo, I.; Vanholder, R. Effective removal of protein-bound uraemic solutes by different convective strategies: A prospective trial. Nephrol. Dial. Transplant. 2009, 24, 562-570. [CrossRef] [PubMed]

341. Meert, N.; Waterloos, M.A.; Van Landschoot, M.; Dhondt, A.; Ledebo, I.; Glorieux, G.; Goeman, J.; Van der Eycken, J.; Vanholder, R. Prospective evaluation of the change of predialysis protein-bound uremic solute concentration with postdilution online hemodiafiltration. Artif. Organs 2010, 34, 580-585. [CrossRef] [PubMed]

342. Eloot, S.; Van Biesen, W.; Dhondt, A.; Van de Wynkele, H.; Glorieux, G.; Verdonck, P.; Vanholder, R. Impact of hemodialysis duration on the removal of uremic retention solutes. Kidney Int. 2008, 73, 765-770. [CrossRef] [PubMed]

343. Raj, D.S.; Ouwendyk, M.; Francoeur, R.; Pierratos, A. Beta(2)-microglobulin kinetics in nocturnal haemodialysis. Nephrol. Dial. Transplant. 2000, 15, 58-64. [CrossRef] [PubMed]

344. Aronin, N.; Krieger, D.T. Plasma immunoreactive beta-endorphin is elevated in uraemia. Clin. Endocrinol. 1983, 18, 459-464. [CrossRef]

345. Peer, G.; Kivity, S.; Agami, O.; Fireman, E.; Silverberg, D.; Blum, M.; laina, A. Randomised crossover trial of naltrexone in uraemic pruritus. Lancet 1996, 348, 1552-1554. [CrossRef]

346. Mettang, T.; Kremer, A.E. Uremic pruritus. Kidney Int. 2015, 87, 685-691. [CrossRef] [PubMed]

347. Mettang, T.; Fischer, F.P.; Dollenbacher, U.; Kuhlman, U. Uraemic pruritus is not related to beta-endorphin serum levels in haemodialysis patients. Nephrol. Dial. Transplant. 1998, 13, 231-232. [CrossRef] [PubMed]

348. Matsuoka, H.; Mulrow, P.J.; Franco-Saenz, R.; Li, C.H. Effects of beta-lipotropin and beta-lipotropin-derived peptides on aldosterone production in the rat adrenal gland. J. Clin. Investig. 1981, 68, 752-759. [CrossRef] [PubMed]

349. Aguilera, A.; Codoceo, R.; Bajo, M.A.; Iglesias, P.; Diez, J.J.; Barril, G.; Cigarran, S.; Alvarez, V.; Celadilla, O.; Fernandez-Perpen, A.; et al. Eating behavior disorders in uremia: A question of balance in appetite regulation. Semin. Dial. 2004, 17, 44-52. [CrossRef] [PubMed]

350. Carrero, J.J.; Aguilera, A.; Stenvinkel, P.; Gil, F.; Selgas, R.; Lindholm, B. Appetite disorders in uremia. J. Ren. Nutr. 2008, 18, 107-113. [CrossRef] [PubMed]

351. Wright, M.; Woodrow, G.; O’Brien, S.; Armstrong, E.; King, N.; Dye, L.; Blundell, J.; Brownjohn, A.; Turney, J. Cholecystokinin and leptin: Their influence upon the eating behaviour and nutrient intake of dialysis patients. Nephrol. Dial. Transplant. 2004, 19, 133-140. [CrossRef] [PubMed]

352. Aguilera, A.; Codoceo, R.; Selgas, R.; Garcia, P.; Picornell, M.; Diaz, C.; Sanchez, C.; Bajo, M.A. Anorexigen (tnf-alpha, cholecystokinin) and orexigen (neuropeptide y) plasma levels in peritoneal dialysis (pd) patients: Their relationship with nutritional parameters. Nephrol. Dial. Transplant. 1998, 13, 1476-1483. [CrossRef] [PubMed]

353. Deppisch, R.M.; Beck, W.; Goehl, H.; Ritz, E. Complement components as uremic toxins and their potential role as mediators of microinflammation. Kidney Int. Suppl. 2001, 78, S271-S277. [CrossRef] [PubMed]

354. Pascual, M.; Steiger, G.; Estreicher, J.; Macon, K.; Volanakis, J.E.; Schifferli, J.A. Metabolism of complement factor d in renal failure. Kidney Int. 1988, 34, 529-536. [CrossRef] [PubMed]

355. Kaiser, J.P.; Oppermann, M.; Gotze, O.; Deppisch, R.; Gohl, H.; Asmus, G.; Rohrich, B.; von Herrath, D.; Schaefer, K. Significant reduction of factor $\mathrm{d}$ and immunosuppressive complement fragment ba by hemofiltration. Blood Purif. 1995, 13, 314-321. [CrossRef] [PubMed]

356. Pascual, M.; Schifferli, J.A. Adsorption of complement factor d by polyacrylonitrile dialysis membranes. Kidney Int. 1993, 43, 903-911. [CrossRef] [PubMed]

357. Oppermann, M.; Kurts, C.; Zierz, R.; Quentin, E.; Weber, M.H.; Gotze, O. Elevated plasma levels of the immunosuppressive complement fragment ba in renal failure. Kidney Int. 1991, 40, 939-947. [CrossRef] [PubMed]

358. Menon, V.; Shlipak, M.G.; Wang, X.; Coresh, J.; Greene, T.; Stevens, L.; Kusek, J.W.; Beck, G.J.; Collins, A.J.; Levey, A.S.; et al. Cystatin c as a risk factor for outcomes in chronic kidney disease. Ann. Int. Med. 2007, 147, 19-27. [CrossRef] [PubMed]

359. Dupont, M.; Wu, Y.; Hazen, S.L.; Tang, W.H. Cystatin c identifies patients with stable chronic heart failure at increased risk for adverse cardiovascular events. Circ. Heart Fail. 2012, 5, 602-609. [CrossRef] [PubMed] 
360. Shlipak, M.G.; Katz, R.; Sarnak, M.J.; Fried, L.F.; Newman, A.B.; Stehman-Breen, C.; Seliger, S.L.; Kestenbaum, B.; Psaty, B.; Tracy, R.P.; et al. Cystatin c and prognosis for cardiovascular and kidney outcomes in elderly persons without chronic kidney disease. Ann. Int. Med. 2006, 145, 237-246. [CrossRef] [PubMed]

361. Knight, E.L.; Verhave, J.C.; Spiegelman, D.; Hillege, H.L.; de Zeeuw, D.; Curhan, G.C.; de Jong, P.E. Factors influencing serum cystatin c levels other than renal function and the impact on renal function measurement. Kidney Int. 2004, 65, 1416-1421. [CrossRef] [PubMed]

362. Stevens, L.A.; Schmid, C.H.; Greene, T.; Li, L.; Beck, G.J.; Joffe, M.M.; Froissart, M.; Kusek, J.W.; Zhang, Y.L.; Coresh, J.; et al. Factors other than glomerular filtration rate affect serum cystatin c levels. Kidney Int. 2009, 75, 652-660. [CrossRef] [PubMed]

363. Softic, A.; Begic, L.; Halilbasic, A.; Vizin, T.; Kos, J. The predictive value of cystatin c in monitoring of b non-hodgkin lymphomas: Relation to biochemical and clinical parameters. ISRN Oncol. 2013, 2013, 752792. [CrossRef] [PubMed]

364. Tizon, B.; Ribe, E.M.; Mi, W.; Troy, C.M.; Levy, E. Cystatin c protects neuronal cells from amyloid-beta-induced toxicity. J. Alzheimers Dis. JAD 2010, 19, 885-894. [CrossRef] [PubMed]

365. Criscione, L.; Nellis, P.; Riniker, B.; Thomann, H.; Burdet, R. Reactivity and sensitivity of mesenteric vascular beds and aortic rings of spontaneously hypertensive rats to endothelin: Effects of calcium entry blockers. Br. J. Pharmacol. 1990, 100, 31-36. [CrossRef] [PubMed]

366. Koyama, H.; Tabata, T.; Nishzawa, Y.; Inoue, T.; Morii, H.; Yamaji, T. Plasma endothelin levels in patients with uraemia. Lancet 1989, 1, 991-992. [CrossRef]

367. Kohan, D.E.; Inscho, E.W.; Wesson, D.; Pollock, D.M. Physiology of endothelin and the kidney. Compr. Physiol. 2011, 1, 883-919. [PubMed]

368. Dhaun, N.; Goddard, J.; Webb, D.J. Endothelin antagonism in patients with nondiabetic chronic kidney disease. Contrib. Nephrol. 2011, 172, 243-254. [PubMed]

369. Dumont, Y.; D'Amours, M.; Lebel, M.; Lariviere, R. Blood pressure-independent effect of angiotensin at1 receptor blockade on renal endothelin-1 production in hypertensive uremic rats. J. Hypertens. 2001, 19, 1479-1487. [CrossRef] [PubMed]

370. Sauter, G.; Wolf, S.; Risler, T.; Brehm, B. Influence of endothelin receptor antagonism on smooth muscle cell proliferation after chronic renal failure. J. Cardiovasc. Pharmacol. 2004, 44 (Suppl. 1), S165-S167. [CrossRef] [PubMed]

371. Amann, K.; Munter, K.; Wessels, S.; Wagner, J.; Balajew, V.; Hergenroder, S.; Mall, G.; Ritz, E. Endothelin a receptor blockade prevents capillary/myocyte mismatch in the heart of uremic animals. J. Am. Soc. Nephrol. JASN 2000, 11, 1702-1711. [PubMed]

372. Dhaun, N.; MacIntyre, I.M.; Kerr, D.; Melville, V.; Johnston, N.R.; Haughie, S.; Goddard, J.; Webb, D.J. Selective endothelin-a receptor antagonism reduces proteinuria, blood pressure, and arterial stiffness in chronic proteinuric kidney disease. Hypertension 2011, 57, 772-779. [CrossRef] [PubMed]

373. Dhaun, N.; Melville, V.; Blackwell, S.; Talwar, D.K.; Johnston, N.R.; Goddard, J.; Webb, D.J. Endothelin-a receptor antagonism modifies cardiovascular risk factors in ckd. J. Am. Soc. Nephrol. JASN 2013, 24, 31-36. [CrossRef] [PubMed]

374. Kohan, D.E.; Pollock, D.M. Endothelin antagonists for diabetic and non-diabetic chronic kidney disease. Br. J. Clin. Pharmacol. 2013, 76, 573-579. [CrossRef] [PubMed]

375. Schneider, M.P.; Mann, J.F. Endothelin antagonism for patients with chronic kidney disease: Still a hope for the future. Nephrol. Dial. Transplant. 2014, 29 (Suppl. 1), i69-i73. [CrossRef] [PubMed]

376. Kuczera, P.; Adamczak, M.; Wiecek, A. Fibroblast growth factor-23-a potential uremic toxin. Toxins 2016, 8, 369. [CrossRef] [PubMed]

377. Rodriguez Ayala, E.; Pecoits-Filho, R.; Heimburger, O.; Lindholm, B.; Nordfors, L.; Stenvinkel, P. Associations between plasma ghrelin levels and body composition in end-stage renal disease: A longitudinal study. Nephrol. Dial. Transplant. 2004, 19, 421-426. [CrossRef] [PubMed]

378. Yoshimoto, A.; Mori, K.; Sugawara, A.; Mukoyama, M.; Yahata, K.; Suganami, T.; Takaya, K.; Hosoda, H.; Kojima, M.; Kangawa, K.; et al. Plasma ghrelin and desacyl ghrelin concentrations in renal failure. J. Am. Soc. Nephrol. JASN 2002, 13, 2748-2752. [CrossRef] [PubMed] 
379. Perez-Fontan, M.; Cordido, F.; Rodriguez-Carmona, A.; Garcia-Naveiro, R.; Isidro, M.L.; Villaverde, P.; Garcia-Buela, J. Acute plasma ghrelin and leptin responses to oral feeding or intraperitoneal hypertonic glucose-based dialysate in patients with chronic renal failure. Kidney Int. 2005, 68, 2877-2885. [CrossRef] [PubMed]

380. Perez-Fontan, M.; Cordido, F.; Rodriguez-Carmona, A.; Peteiro, J.; Garcia-Naveiro, R.; Garcia-Buela, J. Plasma ghrelin levels in patients undergoing haemodialysis and peritoneal dialysis. Nephrol. Dial. Transplant. 2004, 19, 2095-2100. [CrossRef] [PubMed]

381. Klok, M.D.; Jakobsdottir, S.; Drent, M.L. The role of leptin and ghrelin in the regulation of food intake and body weight in humans: A review. Obes. Rev. 2007, 8, 21-34. [CrossRef] [PubMed]

382. Dezaki, K.; Hosoda, H.; Kakei, M.; Hashiguchi, S.; Watanabe, M.; Kangawa, K.; Yada, T. Endogenous ghrelin in pancreatic islets restricts insulin release by attenuating $\mathrm{ca}^{2+}$ signaling in beta-cells: Implication in the glycemic control in rodents. Diabetes 2004, 53, 3142-3151. [CrossRef] [PubMed]

383. Barazzoni, R.; Zanetti, M.; Ferreira, C.; Vinci, P.; Pirulli, A.; Mucci, M.; Dore, F.; Fonda, M.; Ciocchi, B.; Cattin, L.; et al. Relationships between desacylated and acylated ghrelin and insulin sensitivity in the metabolic syndrome. J. Clin. Endocrinol. Metab. 2007, 92, 3935-3940. [CrossRef] [PubMed]

384. Barazzoni, R.; Bosutti, A.; Stebel, M.; Cattin, M.R.; Roder, E.; Visintin, L.; Cattin, L.; Biolo, G.; Zanetti, M.; Guarnieri, G. Ghrelin regulates mitochondrial-lipid metabolism gene expression and tissue fat distribution in liver and skeletal muscle. Am. J. Physiol. Endocrinol. Metabol. 2005, 288, E228-E235. [CrossRef] [PubMed]

385. Asakawa, A.; Inui, A.; Kaga, T.; Yuzuriha, H.; Nagata, T.; Fujimiya, M.; Katsuura, G.; Makino, S.; Fujino, M.A.; Kasuga, M. A role of ghrelin in neuroendocrine and behavioral responses to stress in mice. Neuroendocrinology 2001, 74, 143-147. [CrossRef] [PubMed]

386. Takaya, K.; Ariyasu, H.; Kanamoto, N.; Iwakura, H.; Yoshimoto, A.; Harada, M.; Mori, K.; Komatsu, Y.; Usui, T.; Shimatsu, A.; et al. Ghrelin strongly stimulates growth hormone release in humans. J. Clin. Endocrinol. Metab. 2000, 85, 4908-4911. [CrossRef] [PubMed]

387. Kemp, B.A.; Howell, N.L.; Gildea, J.J.; Keller, S.R.; Padia, S.H. Intrarenal ghrelin receptors regulate enac-dependent sodium reabsorption by a camp-dependent pathway. Kidney Int. 2013, 84, 501-508. [CrossRef] [PubMed]

388. Kemp, B.A.; Howell, N.L.; Gray, J.T.; Keller, S.R.; Nass, R.M.; Padia, S.H. Intrarenal ghrelin infusion stimulates distal nephron-dependent sodium reabsorption in normal rats. Hypertension 2011, 57, 633-639. [CrossRef] [PubMed]

389. Nagaya, N.; Miyatake, K.; Uematsu, M.; Oya, H.; Shimizu, W.; Hosoda, H.; Kojima, M.; Nakanishi, N.; Mori, H.; Kangawa, K. Hemodynamic, renal, and hormonal effects of ghrelin infusion in patients with chronic heart failure. J. Clin. Endocrinol. Metab. 2001, 86, 5854-5859. [CrossRef] [PubMed]

390. Carrero, J.J.; Nakashima, A.; Qureshi, A.R.; Lindholm, B.; Heimburger, O.; Barany, P.; Stenvinkel, P. Protein-energy wasting modifies the association of ghrelin with inflammation, leptin, and mortality in hemodialysis patients. Kidney Int. 2011, 79, 749-756. [CrossRef] [PubMed]

391. Asakawa, A.; Inui, A.; Fujimiya, M.; Sakamaki, R.; Shinfuku, N.; Ueta, Y.; Meguid, M.M.; Kasuga, M. Stomach regulates energy balance via acylated ghrelin and desacyl ghrelin. Gut 2005, 54, 18-24. [CrossRef] [PubMed]

392. Muscaritoli, M.; Molfino, A.; Chiappini, M.G.; Laviano, A.; Ammann, T.; Spinsanti, P.; Melchiorri, D.; Inui, A.; Alegiani, F.; Rossi Fanelli, F. Anorexia in hemodialysis patients: The possible role of des-acyl ghrelin. Am. J. Nephrol. 2007, 27, 360-365. [CrossRef] [PubMed]

393. Buscher, A.K.; Buscher, R.; Hauffa, B.P.; Hoyer, P.F. Alterations in appetite-regulating hormones influence protein-energy wasting in pediatric patients with chronic kidney disease. Pediatr. Nephrol. 2010, 25, 2295-2301. [CrossRef] [PubMed]

394. Uranga, J.; Fuenzalida, R.; Rapoport, A.L.; del Castillo, E. Effect of glucagon and glomerulopressin on the renal function of the dog. Horm. Metab. Res. Horm. Stoffwechs. Horm. Et Metabol. 1979, 11, 275-279. [CrossRef] [PubMed]

395. Hannam-Harris, A.C.; Gordon, J.; Smith, J.L. Immunoglobulin synthesis by neoplastic b lymphocytes: Free light chain synthesis as a marker of b cell differentiation. J. Immunol. 1980, 125, 2177-2181. [PubMed]

396. Hutchison, C.A.; Burmeister, A.; Harding, S.J.; Basnayake, K.; Church, H.; Jesky, M.D.; White, K.; Green, C.E.; Stringer, S.J.; Bassett, P.; et al. Serum polyclonal immunoglobulin free light chain levels predict mortality in people with chronic kidney disease. Mayo Clin. Proc. 2014, 89, 615-622. [CrossRef] [PubMed] 
397. Cohen, G.; Rudnicki, M.; Schmaldienst, S.; Horl, W.H. Effect of dialysis on serum/plasma levels of free immunoglobulin light chains in end-stage renal disease patients. Nephrol. Dial. Transplant. 2002, 17, 879-883. [CrossRef] [PubMed]

398. Brebner, J.A.; Stockley, R.A. Polyclonal free light chains: A biomarker of inflammatory disease or treatment target? F1000 Med. Rep. 2013, 5, 4. [CrossRef] [PubMed]

399. Nakano, T.; Matsui, M.; Inoue, I.; Awata, T.; Katayama, S.; Murakoshi, T. Free immunoglobulin light chain: Its biology and implications in diseases. Clin. Chim. Acta Int. J. Clin. Chem. 2011, 412, 843-849. [CrossRef] [PubMed]

400. Cohen, G.; Haag-Weber, M.; Mai, B.; Deicher, R.; Horl, W.H. Effect of immunoglobulin light chains from hemodialysis and continuous ambulatory peritoneal dialysis patients on polymorphonuclear leukocyte functions. J. Am. Soc. Nephrol. JASN 1995, 6, 1592-1599. [PubMed]

401. Cohen, G.; Horl, W.H. Retinol binding protein isolated from acute renal failure patients inhibits polymorphonuclear leucocyte functions. Eur. J. Clin. Investig. 2004, 34, 774-781. [CrossRef] [PubMed]

402. Christensen, E.I.; Birn, H. Megalin and cubilin: Synergistic endocytic receptors in renal proximal tubule. Am. J. Physiol. Ren. Physiol. 2001, 280, F562-573. [CrossRef] [PubMed]

403. Wochner, R.D.; Strober, W.; Waldmann, T.A. The role of the kidney in the catabolism of bence jones proteins and immunoglobulin fragments. J. Exp. Med. 1967, 126, 207-221. [CrossRef] [PubMed]

404. Maack, T.; Johnson, V.; Kau, S.T.; Figueiredo, J.; Sigulem, D. Renal filtration, transport, and metabolism of low-molecular-weight proteins: A review. Kidney Int. 1979, 16, 251-270. [CrossRef] [PubMed]

405. Sanders, P.W.; Herrera, G.A.; Lott, R.L.; Galla, J.H. Morphologic alterations of the proximal tubules in light chain-related renal disease. Kidney Int. 1988, 33, 881-889. [CrossRef] [PubMed]

406. Hutchison, C.A.; Batuman, V.; Behrens, J.; Bridoux, F.; Sirac, C.; Dispenzieri, A.; Herrera, G.A.; Lachmann, H.; Sanders, P.W.; International, K.; et al. The pathogenesis and diagnosis of acute kidney injury in multiple myeloma. Nat. Rev. Nephrol. 2011, 8, 43-51. [CrossRef] [PubMed]

407. Bradwell, A.R. Serum free light chain measurements move to center stage. Clin. Chem. 2005, 51, 805-807. [CrossRef] [PubMed]

408. Kagimoto, T.; Nakakuma, H.; Hata, H.; Hidaka, M.; Horikawa, K.; Kawaguti, T.; Nagakura, S.; Iwamoto, N.; Shirono, K.; Kawano, F.; et al. Differential glycosylation of bence jones protein and kidney impairment in patients with plasma cell dyscrasia. J. Lab. Clin. Med. 1997, 129, 217-223. [CrossRef]

409. Desjardins, L.; Liabeuf, S.; Lenglet, A.; Lemke, H.D.; Vanholder, R.; Choukroun, G.; Massy, Z.A.; European Uremic Toxin Work Group. Association between free light chain levels, and disease progression and mortality in chronic kidney disease. Toxins 2013, 5, 2058-2073. [CrossRef] [PubMed]

410. Donati, G.; Moretti, M.I.; Baraldi, O.; Spazzoli, A.; Capelli, I.; Comai, G.; Marchetti, A.; Sarma, M.; Mancini, R.; La Manna, G. Removal of free light chains in hemodialysis patients without multiple myeloma: A crossover comparison of three different dialyzers. BMC Nephrol. 2016, 17, 193. [CrossRef] [PubMed]

411. Hutchison, C.A.; Cockwell, P.; Reid, S.; Chandler, K.; Mead, G.P.; Harrison, J.; Hattersley, J.; Evans, N.D.; Chappell, M.J.; Cook, M.; et al. Efficient removal of immunoglobulin free light chains by hemodialysis for multiple myeloma: In vitro and in vivo studies. J. Am. Soc. Nephrol. JASN 2007, 18, 886-895. [CrossRef] [PubMed]

412. Kirsch, A.H.; Lyko, R.; Nilsson, L.G.; Beck, W.; Amdahl, M.; Lechner, P.; Schneider, A.; Wanner, C.; Rosenkranz, A.R.; Krieter, D.H. Performance of hemodialysis with novel medium cut-off dialyzers. Nephrol. Dial. Transplant. 2017, 32, 165-172. [CrossRef] [PubMed]

413. Florens, N.; Calzada, C.; Lyasko, E.; Juillard, L.; Soulage, C.O. Modified lipids and lipoproteins in chronic kidney disease: A new class of uremic toxins. Toxins 2016, 8, 376. [CrossRef] [PubMed]

414. Alix, P.M.; Guebre-Egziabher, F.; Soulage, C.O. Leptin as an uremic toxin: Deleterious role of leptin in chronic kidney disease. Biochimie 2014, 105, 12-21. [CrossRef] [PubMed]

415. Stanley, E.R.; Cifone, M.; Heard, P.M.; Defendi, V. Factors regulating macrophage production and growth: Identity of colony-stimulating factor and macrophage growth factor. J. Exp. Med. 1976, 143, 631-647. [CrossRef] [PubMed]

416. Vadas, M.A.; Clarke, C.; Nicola, N.A.; Lopez, A.F. Correlation between the stimulation of human neutrophil function by monoclonal antibody and by colony-stimulating factor. Blood 1985, 66, 738-741. [PubMed]

417. Weisbart, R.H.; Golde, D.W.; Clark, S.C.; Wong, G.G.; Gasson, J.C. Human granulocyte-macrophage colony-stimulating factor is a neutrophil activator. Nature 1985, 314, 361-363. [CrossRef] [PubMed] 
418. Warren, M.K.; Ralph, P. Macrophage growth factor csf-1 stimulates human monocyte production of interferon, tumor necrosis factor, and colony stimulating activity. J. Immunol. 1986, 137, 2281-2285. [PubMed]

419. Hamilton, J.A. Colony-stimulating factors in inflammation and autoimmunity. Nat. Rev. Immunol. 2008, 8, 533-544. [CrossRef] [PubMed]

420. Le Meur, Y.; Fixe, P.; Aldigier, J.C.; Leroux-Robert, C.; Praloran, V. Macrophage colony stimulating factor involvement in uremic patients. Kidney Int. 1996, 50, 1007-1012. [CrossRef] [PubMed]

421. Tojo, N.; Asakura, E.; Koyama, M.; Tanabe, T.; Nakamura, N. Effects of macrophage colony-stimulating factor $(\mathrm{m}-\mathrm{csf})$ on protease production from monocyte, macrophage and foam cell in vitro: A possible mechanism for anti-atherosclerotic effect of m-csf. Biochim. Biophys. Acta 1999, 1452, 275-284. [CrossRef]

422. Metcalf, D. The colony-stimulating factors and cancer. Nat. Rev. Cancer 2010, 10, 425-434. [CrossRef] [PubMed]

423. Alikhan, M.A.; Jones, C.V.; Williams, T.M.; Beckhouse, A.G.; Fletcher, A.L.; Kett, M.M.; Sakkal, S.; Samuel, C.S.; Ramsay, R.G.; Deane, J.A.; et al. Colony-stimulating factor-1 promotes kidney growth and repair via alteration of macrophage responses. Am. J. Pathol. 2011, 179, 1243-1256. [CrossRef] [PubMed]

424. Kapoor, D.; Aggarwal, S.R.; Singh, N.P.; Thakur, V.; Sarin, S.K. Granulocyte-macrophage colony-stimulating factor enhances the efficacy of hepatitis $b$ virus vaccine in previously unvaccinated haemodialysis patients. J. Viral Hepat. 1999, 6, 405-409. [CrossRef] [PubMed]

425. Zoccali, C.; Ciccarelli, M.; Mallamaci, F.; Maggiore, Q.; Lotti, M.; Zucchelli, G.C. Plasma met-enkephalin and leu-enkephalin in chronic renal failure. Nephrol. Dial. Transplant. 1987, 1, 219-222. [PubMed]

426. Zoccali, C.; Vanholder, R.; Massy, Z.A.; Ortiz, A.; Sarafidis, P.; Dekker, F.W.; Fliser, D.; Fouque, D.; Heine, G.H.; Jager, K.J.; et al. The systemic nature of ckd. Nat. Rev. Nephrol. 2017, 13, 344-358. [CrossRef] [PubMed]

427. Belluzzi, J.D.; Stein, L. Enkephalin may mediate euphoria and drive-reduction reward. Nature 1977, 266, 556-558. [CrossRef] [PubMed]

428. Inturrisi, C.E.; Umans, J.G.; Wolff, D.; Stern, A.S.; Lewis, R.V.; Stein, S.; Udenfriend, S. Analgesic activity of the naturally occurring heptapeptide [met]enkephalin-arg6-phe7. Proc. Natl. Acad. Sci. USA 1980, 77, 5512-5514. [CrossRef] [PubMed]

429. Rotsztejn, W.H.; Drouva, S.V.; Pattou, E.; Kordon, C. Met-enkephalin inhibits in vitro dopamine-induced lhrh release from mediobasal hypothalamus of male rats. Nature 1978, 274, 281-282. [CrossRef] [PubMed]

430. Rhee, H.M.; Eulie, P.J.; Peterson, D.F. Suppression of renal nerve activity by methionine enkephalin in anesthetized rabbits. J. Pharmacol. Exp. Ther. 1985, 234, 534-537. [PubMed]

431. Eklund, S.; Sjoqvist, A.; Fahrenkrug, J.; Jodal, M.; Lundgren, O. Somatostatin and methionine-enkephalin inhibit cholera toxin-induced jejunal net fluid secretion and release of vasoactive intestinal polypeptide in the cat in vivo. Acta Physiol. Scand. 1988, 133, 551-557. [CrossRef] [PubMed]

432. Sheriff, S.; Chance, W.T.; Fischer, J.E.; Balasubramaniam, A. Neuropeptide y treatment and food deprivation increase cyclic amp response element-binding in rat hypothalamus. Mol. Pharmacol. 1997, 51, 597-604. [PubMed]

433. Deshmukh, S.; Phillips, B.G.; O’Dorisio, T.; Flanigan, M.J.; Lim, V.S. Hormonal responses to fasting and refeeding in chronic renal failure patients. Am. J. Physiol. Endocrinol. Metabol. 2005, 288, E47-E55. [CrossRef] [PubMed]

434. Hegbrant, J.; Thysell, H.; Ekman, R. Circulating neuropeptide y in plasma from uremic patients consists of multiple peptide fragments. Peptides 1995, 16, 395-397. [CrossRef]

435. Wiley, J.W.; Gross, R.A.; Lu, Y.X.; Macdonald, R.L. Neuropeptide y reduces calcium current and inhibits acetylcholine release in nodose neurons via a pertussis toxin-sensitive mechanism. J. Neurophysiol. 1990, 63, 1499-1507. [CrossRef] [PubMed]

436. Hackenthal, E.; Aktories, K.; Jakobs, K.H.; Lang, R.E. Neuropeptide y inhibits renin release by a pertussis toxin-sensitive mechanism. Am. J. Physiol. 1987, 252, F543-F550. [CrossRef] [PubMed]

437. Kassis, S.; Olasmaa, M.; Terenius, L.; Fishman, P.H. Neuropeptide y inhibits cardiac adenylate cyclase through a pertussis toxin-sensitive g protein. J. Biol. Chem. 1987, 262, 3429-3431. [PubMed]

438. Suneja, M.; Murry, D.J.; Stokes, J.B.; Lim, V.S. Hormonal regulation of energy-protein homeostasis in hemodialysis patients: An anorexigenic profile that may predispose to adverse cardiovascular outcomes. Am. J. Physiol. Endocrinol. Metabol. 2011, 300, E55-E64. [CrossRef] [PubMed] 
439. Zoccali, C.; Mallamaci, F.; Tripepi, G.; Benedetto, F.A.; Parlongo, S.; Cutrupi, S.; Iellamo, D.; Bonanno, G.; Rapisarda, F.; Fatuzzo, P.; et al. Prospective study of neuropeptide y as an adverse cardiovascular risk factor in end-stage renal disease. J. Am. Soc. Nephrol. JASN 2003, 14, 2611-2617. [CrossRef] [PubMed]

440. Inutsuka, A.; Inui, A.; Tabuchi, S.; Tsunematsu, T.; Lazarus, M.; Yamanaka, A. Concurrent and robust regulation of feeding behaviors and metabolism by orexin neurons. Neuropharmacology 2014, 85, 451-460. [CrossRef] [PubMed]

441. Kitajima, S.; Iwata, Y.; Furuichi, K.; Sagara, A.; Shinozaki, Y.; Toyama, T.; Sakai, N.; Shimizu, M.; Sakurai, T.; Kaneko, S.; et al. Messenger rna expression profile of sleep-related genes in peripheral blood cells in patients with chronic kidney disease. Clin. Exp. Nephrol. 2016, 20, 218-225. [CrossRef] [PubMed]

442. Zheng, D.; Zhao, Y.; Shen, Y.; Chang, X.; Ju, S.; Guo, L. Orexin a-mediated stimulation of 3beta-hsd expression and testosterone production through mapk signaling pathways in primary rat leydig cells. J. Endocrinol. Investig. 2014, 37, 285-292. [CrossRef] [PubMed]

443. Xiao, F.; Jiang, M.; Du, D.; Xia, C.; Wang, J.; Cao, Y.; Shen, L.; Zhu, D. Orexin a regulates cardiovascular responses in stress-induced hypertensive rats. Neuropharmacology 2013, 67, 16-24. [CrossRef] [PubMed]

444. Silver, J.; Naveh-Many, T. Fgf-23 and secondary hyperparathyroidism in chronic kidney disease. Nat. Rev. Nephrol. 2013, 9, 641-649. [CrossRef] [PubMed]

445. Evenepoel, P.; Rodriguez, M.; Ketteler, M. Laboratory abnormalities in ckd-mbd: Markers, predictors, or mediators of disease? Semin. Nephrol. 2014, 34, 151-163. [CrossRef] [PubMed]

446. Floege, J.; Kim, J.; Ireland, E.; Chazot, C.; Drueke, T.; de Francisco, A.; Kronenberg, F.; Marcelli, D.; Passlick-Deetjen, J.; Schernthaner, G.; et al. Serum ipth, calcium and phosphate, and the risk of mortality in a european haemodialysis population. Nephrol. Dial. Transplant. 2011, 26, 1948-1955. [CrossRef] [PubMed]

447. Garrett, G.; Sardiwal, S.; Lamb, E.J.; Goldsmith, D.J. Pth-a particularly tricky hormone: Why measure it at all in kidney patients? Clin. J. Am. Soc. Nephrol. CJASN 2013, 8, 299-312. [CrossRef] [PubMed]

448. Raggi, P.; Chertow, G.M.; Torres, P.U.; Csiky, B.; Naso, A.; Nossuli, K.; Moustafa, M.; Goodman, W.G.; Lopez, N.; Downey, G.; et al. The advance study: A randomized study to evaluate the effects of cinacalcet plus low-dose vitamin d on vascular calcification in patients on hemodialysis. Nephrol. Dial. Transplant. 2011, 26, 1327-1339. [CrossRef] [PubMed]

449. Investigators, E.T.; Chertow, G.M.; Block, G.A.; Correa-Rotter, R.; Drueke, T.B.; Floege, J.; Goodman, W.G.; Herzog, C.A.; Kubo, Y.; London, G.M.; et al. Effect of cinacalcet on cardiovascular disease in patients undergoing dialysis. N. Engl. J. Med. 2012, 367, 2482-2494. [CrossRef] [PubMed]

450. Moe, S.M.; Chertow, G.M.; Parfrey, P.S.; Kubo, Y.; Block, G.A.; Correa-Rotter, R.; Drueke, T.B.; Herzog, C.A.; London, G.M.; Mahaffey, K.W.; et al. Cinacalcet, fibroblast growth factor-23, and cardiovascular disease in hemodialysis: The evaluation of cinacalcet hcl therapy to lower cardiovascular events (evolve) trial. Circulation 2015, 132, 27-39. [CrossRef] [PubMed]

451. Koizumi, M.; Komaba, H.; Fukagawa, M. Parathyroid function in chronic kidney disease: Role of fgf23-klotho axis. Contrib. Nephrol. 2013, 180, 110-123. [PubMed]

452. Shalhoub, V.; Shatzen, E.M.; Ward, S.C.; Davis, J.; Stevens, J.; Bi, V.; Renshaw, L.; Hawkins, N.; Wang, W.; Chen, C.; et al. Fgf23 neutralization improves chronic kidney disease-associated hyperparathyroidism yet increases mortality. J. Clin. Investig. 2012, 122, 2543-2553. [CrossRef] [PubMed]

453. Speeckaert, M.M.; Speeckaert, R.; Carrero, J.J.; Vanholder, R.; Delanghe, J.R. Biology of human pentraxin 3 (ptx3) in acute and chronic kidney disease. J. Clin. Immunol. 2013, 33, 881-890. [CrossRef] [PubMed]

454. Lech, M.; Rommele, C.; Anders, H.J. Pentraxins in nephrology: C-reactive protein, serum amyloid p and pentraxin-3. Nephrol. Dial. Transplant. 2013, 28, 803-811. [CrossRef] [PubMed]

455. Tong, M.; Carrero, J.J.; Qureshi, A.R.; Anderstam, B.; Heimburger, O.; Barany, P.; Axelsson, J.; Alvestrand, A.; Stenvinkel, P.; Lindholm, B.; et al. Plasma pentraxin 3 in patients with chronic kidney disease: Associations with renal function, protein-energy wasting, cardiovascular disease, and mortality. Clin. J. Am. Soc. Nephrol. CJASN 2007, 2, 889-897. [CrossRef] [PubMed]

456. Boehme, M.; Kaehne, F.; Kuehne, A.; Bernhardt, W.; Schroder, M.; Pommer, W.; Fischer, C.; Becker, H.; Muller, C.; Schindler, R. Pentraxin 3 is elevated in haemodialysis patients and is associated with cardiovascular disease. Nephrol. Dial. Transplant. 2007, 22, 2224-2229. [CrossRef] [PubMed] 
457. Suliman, M.E.; Qureshi, A.R.; Carrero, J.J.; Barany, P.; Yilmaz, M.I.; Snaedal-Jonsdottir, S.; Alvestrand, A.; Heimburger, O.; Lindholm, B.; Stenvinkel, P. The long pentraxin ptx-3 in prevalent hemodialysis patients: Associations with comorbidities and mortality. QJM Mon. J. Assoc. Physicians 2008, 101, 397-405. [CrossRef] [PubMed]

458. Hung, T.W.; Tsai, J.P.; Lin, S.H.; Lee, C.H.; Hsieh, Y.H.; Chang, H.R. Pentraxin 3 activates jnk signaling and regulates the epithelial-to-mesenchymal transition in renal fibrosis. Cell. Physiol. Biochem. Int. J. Exp. Cell. Physiol. Biochem. Pharmacol. 2016, 40, 1029-1038. [CrossRef] [PubMed]

459. Savchenko, A.; Imamura, M.; Ohashi, R.; Jiang, S.; Kawasaki, T.; Hasegawa, G.; Emura, I.; Iwanari, H.; Sagara, M.; Tanaka, T.; et al. Expression of pentraxin 3 (ptx3) in human atherosclerotic lesions. J. Pathol. 2008, 215, 48-55. [CrossRef] [PubMed]

460. Yilmaz, M.I.; Sonmez, A.; Ortiz, A.; Saglam, M.; Kilic, S.; Eyileten, T.; Caglar, K.; Oguz, Y.; Vural, A.; Cakar, M.; et al. Soluble tweak and ptx3 in nondialysis ckd patients: Impact on endothelial dysfunction and cardiovascular outcomes. Clin. J. Am. Soc. Nephrol. CJASN 2011, 6, 785-792. [CrossRef] [PubMed]

461. Liu, H.; Guan, S.; Fang, W.; Yuan, F.; Zhang, M.; Qu, X. Associations between pentraxin 3 and severity of coronary artery disease. BMJ Open 2015, 5, e007123. [CrossRef] [PubMed]

462. Sjoberg, B.; Qureshi, A.R.; Heimburger, O.; Stenvinkel, P.; Lind, L.; Larsson, A.; Barany, P.; Arnlov, J. Association between levels of pentraxin 3 and incidence of chronic kidney disease in the elderly. J. Int. Med. 2016, 279, 173-179. [CrossRef] [PubMed]

463. Yilmaz, M.I.; Axelsson, J.; Sonmez, A.; Carrero, J.J.; Saglam, M.; Eyileten, T.; Caglar, K.; Kirkpantur, A.; Celik, T.; Oguz, Y.; et al. Effect of renin angiotensin system blockade on pentraxin 3 levels in type-2 diabetic patients with proteinuria. Clin. J. Am. Soc. Nephrol. CJASN 2009, 4, 535-541. [CrossRef] [PubMed]

464. Yilmaz, M.I.; Carrero, J.J.; Martin-Ventura, J.L.; Sonmez, A.; Saglam, M.; Celik, T.; Yaman, H.; Yenicesu, M.; Eyileten, T.; Moreno, J.A.; et al. Combined therapy with renin-angiotensin system and calcium channel blockers in type 2 diabetic hypertensive patients with proteinuria: Effects on soluble tweak, ptx3, and flow-mediated dilation. Clin. J. Am. Soc. Nephrol. CJASN 2010, 5, 1174-1181. [CrossRef] [PubMed]

465. Sun, H.; Tian, J.; Xian, W.; Xie, T.; Yang, X. Pentraxin-3 attenuates renal damage in diabetic nephropathy by promoting $\mathrm{m} 2$ macrophage differentiation. Inflammation 2015, 38, 1739-1747. [CrossRef] [PubMed]

466. Norata, G.D.; Marchesi, P.; Pulakazhi Venu, V.K.; Pasqualini, F.; Anselmo, A.; Moalli, F.; Pizzitola, I.; Garlanda, C.; Mantovani, A.; Catapano, A.L. Deficiency of the long pentraxin ptx3 promotes vascular inflammation and atherosclerosis. Circulation 2009, 120, 699-708. [CrossRef] [PubMed]

467. Miyamoto, T.; Rashid Qureshi, A.; Heimburger, O.; Barany, P.; Carrero, K.; Sjoberg, B.; Lindholm, B.; Stenvinkel, P.; Carrero, J.J. Inverse relationship between the inflammatory marker pentraxin-3, fat body mass, and abdominal obesity in end-stage renal disease. Clin. J. Am. Soc. Nephrol. CJASN 2011, 6, 2785-2791. [CrossRef] [PubMed]

468. Witasp, A.; Ryden, M.; Carrero, J.J.; Qureshi, A.R.; Nordfors, L.; Naslund, E.; Hammarqvist, F.; Arefin, S.; Kublickiene, K.; Stenvinkel, P. Elevated circulating levels and tissue expression of pentraxin 3 in uremia: A reflection of endothelial dysfunction. PLoS ONE 2013, 8, e63493. [CrossRef] [PubMed]

469. Batterham, R.L.; Cohen, M.A.; Ellis, S.M.; Le Roux, C.W.; Withers, D.J.; Frost, G.S.; Ghatei, M.A.; Bloom, S.R. Inhibition of food intake in obese subjects by peptide yy3-36. N. Engl. J. Med. 2003, 349, 941-948. [CrossRef] [PubMed]

470. Batterham, R.L.; Cowley, M.A.; Small, C.J.; Herzog, H.; Cohen, M.A.; Dakin, C.L.; Wren, A.M.; Brynes, A.E.; Low, M.J.; Ghatei, M.A.; et al. Gut hormone pyy(3-36) physiologically inhibits food intake. Nature 2002, 418, 650-654. [CrossRef] [PubMed]

471. Wiley, J.W.; Lu, Y.X.; Chung, O.Y. Mechanism of action of peptide yy to inhibit gastric motility. Gastroenterology 1991, 100, 865-872. [CrossRef]

472. Perez-Fontan, M.; Cordido, F.; Rodriguez-Carmona, A.; Penin, M.; Diaz-Cambre, H.; Lopez-Muniz, A.; Sangiao-Alvarellos, S.; Garcia-Buela, J. Short-term regulation of peptide yy secretion by a mixed meal or peritoneal glucose-based dialysate in patients with chronic renal failure. Nephrol. Dial. Transplant. 2008, 23, 3696-3703. [CrossRef] [PubMed]

473. Playford, R.J.; Mehta, S.; Upton, P.; Rentch, R.; Moss, S.; Calam, J.; Bloom, S.; Payne, N.; Ghatei, M.; Edwards, R.; et al. Effect of peptide yy on human renal function. Am. J. Physiol. 1995, 268, F754-759. [CrossRef] [PubMed] 
474. Sam, A.H.; Gunner, D.J.; King, A.; Persaud, S.J.; Brooks, L.; Hostomska, K.; Ford, H.E.; Liu, B.; Ghatei, M.A.; Bloom, S.R.; et al. Selective ablation of peptide yy cells in adult mice reveals their role in beta cell survival. Gastroenterology 2012, 143, 459-468. [CrossRef] [PubMed]

475. Chandarana, K.; Gelegen, C.; Irvine, E.E.; Choudhury, A.I.; Amouyal, C.; Andreelli, F.; Withers, D.J.; Batterham, R.L. Peripheral activation of the y2-receptor promotes secretion of glp-1 and improves glucose tolerance. Mol. Metabol. 2013, 2, 142-152. [CrossRef] [PubMed]

476. Carrero, J.J.; Kyriazis, J.; Sonmez, A.; Tzanakis, I.; Qureshi, A.R.; Stenvinkel, P.; Saglam, M.; Stylianou, K.; Yaman, H.; Taslipinar, A.; et al. Prolactin levels, endothelial dysfunction, and the risk of cardiovascular events and mortality in patients with ckd. Clin. J. Am. Soc. Nephrol. CJASN 2012, 7, 207-215. [CrossRef] [PubMed]

477. Hou, S.H.; Grossman, S.; Molitch, M.E. Hyperprolactinemia in patients with renal insufficiency and chronic renal failure requiring hemodialysis or chronic ambulatory peritoneal dialysis. Am. J. Kidney Dis. 1985, 6, 245-249. [CrossRef]

478. Cowden, E.A.; Ratcliffe, W.A.; Ratcliffe, J.G.; Dobbie, J.W.; Kennedy, A.C. Hyperprolactinaemia in renal disease. Clin. Endocrinol. 1978, 9, 241-248. [CrossRef]

479. Gomez, F.; de la Cueva, R.; Wauters, J.P.; Lemarchand-Beraud, T. Endocrine abnormalities in patients undergoing long-term hemodialysis. The role of prolactin. Am. J. Med. 1980, 68, 522-530. [CrossRef]

480. Freeman, M.E.; Kanyicska, B.; Lerant, A.; Nagy, G. Prolactin: Structure, function, and regulation of secretion. Physiol. Rev. 2000, 80, 1523-1631. [CrossRef] [PubMed]

481. Palmer, B.F. Sexual dysfunction in uremia. J. Am. Soc. Nephrol. JASN 1999, 10, 1381-1388. [PubMed]

482. Wallaschofski, H.; Kobsar, A.; Sokolova, O.; Siegemund, A.; Stepan, H.; Faber, R.; Eigenthaler, M.; Lohmann, T. Differences in platelet activation by prolactin and leptin. Horm. Metab. Res. Horm. Stoffwechs. Horm. Et Metabol. 2004, 36, 453-457. [CrossRef] [PubMed]

483. Corona, G.; Rastrelli, G.; Boddi, V.; Monami, M.; Melani, C.; Balzi, D.; Sforza, A.; Forti, G.; Mannucci, E.; Maggi, M. Prolactin levels independently predict major cardiovascular events in patients with erectile dysfunction. Int. J. Androl. 2011, 34, 217-224. [CrossRef] [PubMed]

484. Noy, N. Retinoid-binding proteins: Mediators of retinoid action. Biochem. J. 2000, 348 Pt 3, $481-495$. [CrossRef] [PubMed]

485. Vannucchi, M.T.; Vannucchi, H.; Humphreys, M. Serum levels of vitamin a and retinol binding protein in chronic renal patients treated by continuous ambulatorial peritoneal dialysis. Int. J. Vitam. Nutr. Res. Int. Z. Fur Vitam. Ernahrungsforschung. J. Int. Vitaminol. Nutr. 1992, 62, 107-112.

486. Smith, F.R.; Goodman, D.S. The effects of diseases of the liver, thyroid, and kidneys on the transport of vitamin a in human plasma. J. Clin. Investig. 1971, 50, 2426-2436. [CrossRef] [PubMed]

487. Frey, S.K.; Nagl, B.; Henze, A.; Raila, J.; Schlosser, B.; Berg, T.; Tepel, M.; Zidek, W.; Weickert, M.O.; Pfeiffer, A.F.; et al. Isoforms of retinol binding protein 4 (rbp4) are increased in chronic diseases of the kidney but not of the liver. Lipids Health Dis. 2008, 7, 29. [CrossRef] [PubMed]

488. Axelsson, J.; O’Byrne, S.M.; Blaner, W.S.; Carrero, J.J.; Bruchfeld, A.; Heimburger, O.; Barany, P.; Lindholm, B.; Stenvinkel, P. Serum retinol-binding protein concentration and its association with components of the uremic metabolic syndrome in nondiabetic patients with chronic kidney disease stage 5. Am. J. Nephrol. 2009, 29, 447-453. [CrossRef] [PubMed]

489. Kabanda, A.; Jadoul, M.; Pochet, J.M.; Lauwerys, R.; van Ypersele de Strihou, C.; Bernard, A. Determinants of the serum concentrations of low molecular weight proteins in patients on maintenance hemodialysis. Kidney Int. 1994, 45, 1689-1696. [CrossRef] [PubMed]

490. Donadio, C.; Lucchesi, A.; Ardini, M.; Giordani, R. Cystatin c, beta 2-microglobulin, and retinol-binding protein as indicators of glomerular filtration rate: Comparison with plasma creatinine. J. Pharm. Biol. Anal. 2001, 24, 835-842. [CrossRef]

491. Chen, C.H.; Hsieh, T.J.; Lin, K.D.; Lin, H.Y.; Lee, M.Y.; Hung, W.W.; Hsiao, P.J.; Shin, S.J. Increased unbound retinol-binding protein 4 concentration induces apoptosis through receptor-mediated signaling. J. Biol. Chem. 2012, 287, 9694-9707. [CrossRef] [PubMed]

492. Farjo, K.M.; Farjo, R.A.; Halsey, S.; Moiseyev, G.; Ma, J.X. Retinol-binding protein 4 induces inflammation in human endothelial cells by an nadph oxidase- and nuclear factor kappa b-dependent and retinol-independent mechanism. Mol. Cell. Biol. 2012, 32, 5103-5115. [CrossRef] [PubMed] 
493. Ingelsson, E.; Sundstrom, J.; Melhus, H.; Michaelsson, K.; Berne, C.; Vasan, R.S.; Riserus, U.; Blomhoff, R.; Lind, L.; Arnlov, J. Circulating retinol-binding protein 4, cardiovascular risk factors and prevalent cardiovascular disease in elderly. Atherosclerosis 2009, 206, 239-244. [CrossRef] [PubMed]

494. Bobbert, T.; Raila, J.; Schwarz, F.; Mai, K.; Henze, A.; Pfeiffer, A.F.; Schweigert, F.J.; Spranger, J. Relation between retinol, retinol-binding protein 4 , transthyretin and carotid intima media thickness. Atherosclerosis 2010, 213, 549-551. [CrossRef] [PubMed]

495. Von Eynatten, M.; Lepper, P.M.; Liu, D.; Lang, K.; Baumann, M.; Nawroth, P.P.; Bierhaus, A.; Dugi, K.A.; Heemann, U.; Allolio, B.; et al. Retinol-binding protein 4 is associated with components of the metabolic syndrome, but not with insulin resistance, in men with type 2 diabetes or coronary artery disease. Diabetologia 2007, 50, 1930-1937. [CrossRef] [PubMed]

496. Lin, C.J.; Chu, N.F.; Hung, Y.J.; Chang, J.B.; He, C.T.; Hsiao, F.C.; Hsieh, C.H. The association of retinol-binding protein 4 with metabolic syndrome and obesity in adolescents: The effects of gender and sex hormones. Clin. Pediatr. 2013, 52, 16-23. [CrossRef] [PubMed]

497. Qi, Q.; Yu, Z.; Ye, X.; Zhao, F.; Huang, P.; Hu, F.B.; Franco, O.H.; Wang, J.; Li, H.; Liu, Y.; et al. Elevated retinol-binding protein 4 levels are associated with metabolic syndrome in chinese people. J. Clin. Endocrinol. Metab. 2007, 92, 4827-4834. [CrossRef] [PubMed]

498. Chu, C.H.; Lam, H.C.; Lee, J.K.; Lu, C.C.; Sun, C.C.; Cheng, H.J.; Wang, M.C.; Chuang, M.J. Elevated serum retinol-binding protein 4 concentrations are associated with chronic kidney disease but not with the higher carotid intima-media thickness in type 2 diabetic subjects. Endocr. J. 2011, 58, 841-847. [CrossRef] [PubMed]

499. Domingos, M.A.; Moreira, S.R.; Gomez, L.; Goulart, A.; Lotufo, P.A.; Bensenor, I.; Titan, S. Urinary retinol-binding protein: Relationship to renal function and cardiovascular risk factors in chronic kidney disease. PLoS ONE 2016, 11, e0162782. [CrossRef] [PubMed]

500. Dalmo, J.; Westberg, E.; Barregard, L.; Svedbom, L.; Johansson, M.; Tornqvist, M.; Forssell-Aronsson, E. Evaluation of retinol binding protein 4 and carbamoylated haemoglobin as potential renal toxicity biomarkers in adult mice treated with (177)lu-octreotate. EJNMMI Res. 2014, 4, 59. [CrossRef] [PubMed]

501. Cohen, G.; Glorieux, G.; Thornalley, P.; Schepers, E.; Meert, N.; Jankowski, J.; Jankowski, V.; Argiles, A.; Anderstam, B.; Brunet, P.; et al. Review on uraemic toxins iii: Recommendations for handling uraemic retention solutes in vitro-Towards a standardized approach for research on uraemia. Nephrol. Dial. Transplant. 2007, 22, 3381-3390. [CrossRef] [PubMed]

502. Rossi, M.; Johnson, D.W.; Morrison, M.; Pascoe, E.M.; Coombes, J.S.; Forbes, J.M.; Szeto, C.C.; McWhinney, B.C.; Ungerer, J.P.; Campbell, K.L. Synbiotics easing renal failure by improving gut microbiology (synergy): A randomized trial. Clin. J. Am. Soc. Nephrol. CJASN 2016, 11, 223-231. [CrossRef] [PubMed]

503. Rocco, M.V.; Lockridge, R.S., Jr.; Beck, G.J.; Eggers, P.W.; Gassman, J.J.; Greene, T.; Larive, B.; Chan, C.T.; Chertow, G.M.; Copland, M.; et al. The effects of frequent nocturnal home hemodialysis: The frequent hemodialysis network nocturnal trial. Kidney Int. 2011, 80, 1080-1091. [CrossRef] [PubMed] 